Smith and Moore

Exotic Cultivated Ferns (1858)

QR

523

.5664
1858

BOT 





\section{AN ACCOUNT \\ $\mathrm{OF}$}

\section{EXOTIC}

\section{CULTIVATED FERNS,}

Described by SMITH \& TH. MOORE, F.B.S.

(Curator of the Botanic Garden, Chelsea,)

WITH

GENERAL HINTS ON THEIR CULTURE,

SYNOPSIS OF GENERA AND SPECIES,

(POLYPODIACE $\mathbb{E}$, GRAMMITIS TO PLATYLONA,)

ILLUSTRATED BY FOR'TY-FOUR ENGRAVINGS.

WARD'S FERN HOUSE AND FERNS, WARRINGTON'S PLANT CASE, ITC.

(UNPUBLISHED.)

LONDON.

1858. 



\section{N'RODUCTION.}

मुपE Ferns form a group of plants which are considered as the most highly developed of that 2 large class which produce no visible flowers, and of which other familiar and recognizable groups are the Mosses, the Lichens, the Sea-weeds, and the Funguses. These, as a whole, were well named Cryptogamous plants by Linnæus, inasmuch as the process by which their seeds, or the equivalent of seeds, are produced, are hidden and mysterious, compared with what we are enabled to observe in those orders of vegetation, - higher orders as they are termed,-which produce perfect flowers as the medium by whose agency their seeds are organiscd.

Among the groups into which Cryptogamous plants are separated for the convenience of classification, the Ferns are known by possessing a certain degree of vascularity in their structure, and by producing spores-that is minute reproductive atoms-of only one kind, within little one-celled cases or receptacles that are collected into groups occupying a portion, rarely the whole, of either the back or the margin of their leaves. The true Ferns have their young leaves rolled up spirally, and in gradually unfolding present the form of a crozier; but a small group, differing chiefly in having their young parts folded and not rolled up, and which may be considered as spurious Ferns, are conveniently associated with them.

In briefly describing what is the structure of Ferns, and the terms applied to the modifications of their respective parts, with sufficient distinctness to render the descriptions of the species which occupy another part of these pages the more intelligible, it will be convenient to consider them as consisting of four series of organs-the roots, the stems, the fronds, and the fructification.

The roots of Ferns are fibrous, and we believe, in all the true Ferns, are covered with a pile of soft close hairs or down, not unfrequently of a ferruginous or rust-colour, and they generally grow more or less matted or entangled, especially if they are in contact with any hard surface, such as the rocks or tree-trunks on which many of them grow naturally; and the same is observed when they are placed under the eireumstances which attend their artificial cultivation. The true roots must not be confounded with the stems, which sometimes creep extensively beneath the soil, and have, more or less, the appearance of thick fleshy roots. The roots of the spurious Ferns consist of thick straight rigid fibres.

The stems, or rhizomes, assume two perfectly distinct forms. In some Ferns, as already intimated, they creep extensively either beneath or upon the surface of the soil, or over the rock or trunk which supports them. These throw up their fronds at intervals, the growing point of the stem being in advance of the youngest fronds, and the fronds themselves being 
more or less distant. In other Ferns, the proper stem may be considered as consisting chiefly of a growing point, from the centre of which the young fronds are developed, the bases of the older fronds forming the trunk, whieh is gradually decaying at one end and extending at the other; the proper roots being protruded from between the bases of the older fronds. Stems of this structure, which is called the tufted mode of growth, assume either an erect or decumbent position,-in the former case sometimes elongating and becoming caudiciform, and in the latter beeoming more or less creeping, though obviously differing in habit from the ereeping stems first described. These distinct modes of development, $\mathrm{Mr}$. Smith-the active Curator of the Royal Botanic Garden at Kew, and probably the best practical pteridologist in the kingdom-has lately proposed to adopt as the basis of a new method of classification-a method displaying much ingenuity and depth of observation, but which it is to be feared, if generally applied, would, practically, throw almost insuperable impediments in the way of the study and knowledge of Ferns, by the altered nomenelature which would be necessary; and theoretieally, is hardly to be admitted as having greater claim to precedence than the system whieh is founded on the nature and variations of the fructifieation and venation, and which is now so extensively adopted.

In the group of Marattiacex, the rhizome is usually thick and fleshy, and more or less globose.

The fronds of Ferns are those parts which have the appearance of leaves, and for general purposes may be considered as the equivalents of leaves, though there are some technical abjeetions to their being regarded as leaves proper. The fronds consist of two parts-the stipes or stalk, and the leafy portion which it supports; which latter is generally meant when the term frond is used deseriptively. The stipes is either adherent to the stem, or there is at or uear its base a natural joiuing or articulation, at which, when its fuctions are no longer in play, it separates spontaneously. When this latter structure accurs, the frond is said to be artieulated with the stem. Sometimes the leafy parts of the frond are articulated in a similar way, but this occurs less frequently. The continuation of the stipes through the leafy part in the Ferus having divided fronds, is called the rachis.

The fronds-in the leafy part-are either simple or more or less divided, and have different terms applied to them, according to the nature of the division. If a frond is separated into distinct leaflets, and these are simple, it is said to be pinnate (Fig. 5, 36, \&c.); if the leaflets, called also pinnæ, are again divided into distinct leaflets, they are said to be pinnate, and the frond is bipinnate; when they are again divided the frond becomes tripinnate, and so on. If the divisions are not distinct, but are united at the base, and are not otherwise divided, they are then pinnatifid (Fig. 2, 14, \&c.) ; and so, when twice or thrice divided on the same plan, they beeome bipinnatifid, tripinnatifid, and so on. Fronds very much divided, that is, more divided than tripinnate, are in general terms called decompound. These and similar terms, descriptive of form, are applied in the same sense as in other departments of botany : such are flabellate, palmate, pedate, sagittate, \&c.

The fronds are traversed by a series of veins, which are, in fact, the ramifications of the system of vascular structure, whieh forms the main bulk of the stipes and rachis. The midrib of a frond or pinna is sometimes called the costa: the first series of brauches from this are the veins, the secondary series the venules, and the tertiary series the veinlets (Fig. 13, 59, \&c.). The arrangement of these different series of veins in the substance of the frond is called the venation.

Great variety of venation is exhibited among the Ferns, the various modes in whieh it 
occurs being so distinctive and so constant that this feature is, by many good botanists, employed to furnish auxiliary, or even sometimes primary, characteristics for the distinguishing of the genera. The prineipal forms of venation have been distinguished by names, which we will endenvour to explain by the aid of references to the figures illustrative of the genera. When the veins are unbranched, they are said to be simple (Fig. 7, 81, \&c.); and the same applies to venules and veinlets similarly circumstanced. Sometimes they are branched once or oftcner in a dichotomous manner, and are then said to be forked (Fig. 2, 69, \&c.); sometimes the veins are pinnately eostaform, that is, resembling a midrib and having the venules or branches either simple or forked (Fig. 9, 41, 61, 81, \&c.). In some they are equal, that is, produced alike on both sides of a central midrib (Fig. 49,67, \&c.); in others they are radiate, and have no midrib (Fig. 32, 77, \&c.); in others they are eecentric, or produced from one side of a marginal rib (Fig. 72). In all these cases the apices of the veins may terminate at or within the margin of the frond or of its divisions (as seen in Fig. 22, 23, 44, 70, \&c.), when they are said to be direet and free; but similar forms of venation may occur, having the apices of the veins of either the primary, secondary, or tertiary scrics combined in some way or other. If the whole system of venation is uniformly combined, so as to form a complete network, it is then said to be retieulated or netted (Fig. 20, 29, 38, 89, 92, 101, \&c.). If the simple, or dichotomous, or pinnately costæform veins are united by a continuous vein parallel with and close to the margin, this form of venation is called the transverse marginal (Fig. 25, 51, \&c.). Sometimes the apices of the venules of one series or fascicle combine with the apices of the adjoining series, and this is called anastomosing: of this arrangement there are some modifications, such as the angular anastomosing (Fig. 10, 61, \&c.), and the areuate anastomosing (Fig. 8, $11, \& c$.$) , which varieties are further modified by producing from their exterior side one or$ more outwardly directed (and called exeurvent) tertiary veins or veinlets, which are eithcr frec, terminating in the areoles or margin (Fig. 10, 12, 59, \&c.), or anastomose with the next supcrior venules (Fig. 61, \&c.). In some forms of reticulated venation the venules are irregularly combincd, the areoles or meshes producing from their sides certain simple or forked variously directed veinlets, which terminate within the unequal-sidcd arcoles. This arrangement of the renation is called eompound anastomosing (Fig. 14, 31, 57, 71, \&c.). The veins are said to be external when they are more or less superficial, distinct, or elevated above the surface of the frond, and internal when they are immersed in the substance of the frond; in which latter ease they often become indistinct, and are to be seen only after careful maccration of the frond. In these definitions we have mainly adopted Mr. Smith's terms and explanations.

From some part of the venules or vcinlets, which part becomes thickened, the fructification is produced on what is called the receptacle, which organ is said to be terminal when it is situate at the apex of the vein or venule (Fig. 11); medial when situate betwcen the base and the apex (Fig. 70); axillary when on the point of forking (Fig. 83); and compital when seated on the angular crossing or points of confluence of two or more venules or veinlets (Fig. 14). It consists, in most cases, of one-celled spore-cases or sporangia, more or less completely girt by an clastic ring, but in some cases, of sporangia which are many-celled or destitute of the ring. These spore-cases are mostly collected into masses, which masses usually consist of multitudes of crowded spore-cases, and are the sori. The latter are either round (Fig. 14, 57, 67, \&c.) or elongated; sometimes anorphous, that is of no determinable form (Fig. 23, 29, 30, \&c.) In most cases they are dorsal, that is situate on some part of the back of the frond; but sometimes they are marginal (Fig. 77, \&c.), or extra-marginal (Fig. 75, 89, \&c.). The elongated sori are oblong (Fig. 1, 50, \&c.), or linear (Fig. 47, 49, 51, \&c.), or continuous (Fig. 38, 71, \&c.); 
and either form an angle with the midrib, when they are said to be oblique (Fig. 51), or run parallel with the margin (Fig. 38), or with the midrib (Fig. 44). The sori are in some of these groups entirely exposed on the surface of the frond, and in others are covered by a scale or membrane of the same form as the sorus, and which completely invests the receptacle in the earlier stages of development. This cover is the indusium proper, and takes some modification of either a plane, vaulted, or cup-shaped form. The entire margin or lobules of a frond are sometimes changed in texture, and form an accessory indusium, which is more or less conjoined with the proper indusium, and thus constitutes a marginal cyst containing the sporecases and opening exteriorly : it may be vertical (Fig. 76) or reflexed (Fig. 79); urn-shaped (Fig. 76), calyciform (Fig. 83), or two-lipped (Fig. 78). Sometimes the fertile fronds are contracted, and inclose the sori by their revolute margins, which thus constitute an universal indusium (Fig. 3, 58, \&c.).

The further differences of structure, and the various modifications which occur and serve to distinguish the groups from one another, will be explained further on. One of the most striking of these differences is the paniculate arrangement of the sori, which occurs among the Osmundaceæ, and some of the Schizæaceæ and Ophioglossaceæ. The fructification of the Marattiaceæ is also of a very peculiar nature.

As we have in most cases adopted Mr. Smith's views of genera and species, we have also, in these succinct explanations of terms and of structure, endeavoured to assimilate our remarks with the definitions which accompany his paper, in Hooker's Journal of Botamy, in order to secure the advantages of uniformity in terminology.-M. 


\section{GENERAT, HINTS ON FERN CULTURE.}

gIHE Ferns naturally divide into three prineipal groups, as regards the climatal eonditions affecting If their eultivation - the hothouse species, the greenhouse speeies, and the hardy species, - of whiels latter, a somewhat more tender subdivision needs the proteetion of a eold frame.

In the pure atmosphere of a rural situation, the hardy raee of Ferns require only to be planted in suitable eonditions of shade and moisture, in order to secure their healthy development; and many of what are ealled frame speeies, if plaeed under sueh conditions in a sheltered position, will not snfier any injury from elimatal eauses, espeeially if they are at all guarded from exeess of wet. But in the smoky sooty atmosphere of erowded eities, none but a very few of the most robust of the hardy sorts will even survive, unless sheltered by some permanent eovering, such as glass. To cultivate even the hardy sorts, then, in sueh murky situations, where they beeome especially valuable from thcir cheerful aspect and the often impossibility of eultivating flowering-plants, a complete eovering of some kind is indispensable, and this is best constructed of glass. No artificial heating is neeessary for them; but, merely an inelosure which may shut the plants up, and seclnde them, as far as practieable, from the fuliginous atmosphere of a thiekly inhabited loeality. The size might vary from the small glazcd ease on the window-ledge, to the inelosed eourt-yard; and, in cither case, aeeording to the space, the interior should be disposed in the pieturesqne style to which the dignified title of rock-work is gencrally applied. Sueh an arrangement of the surfaee is, at least, the most appropriate, both as to the wants of the plants, and as to their adaptation to an ornamental purpose. If grown in pots a low pit is most suitable; but for eonvenienee sake it should be eontrived so that a pathway inside, with sufineient head-room, may afford faeility of aeeess.

The greenhouse speeies may be grown in a similar pit-like strueture, with the addition of suffieicnt means of heating to exclude frost. The plants are undoubtedly best situated, as well as most cffective, when planted out on roek-work among winding pathways; but if it is preferred to grow them in pots, any simple and eonvenient form of low close pit may be adopted.

The same eonsiderations, exeept as to the heating, apply to the eulture of the stove speeies. For a very limited eolleetion a small pit would be best, on aeeount of the eeonomy of keeping up the nceessary heat; but where the eolleetion is eonsiderable a larger house, with rock-work embankments of tasteful and irregular outline, should be preferred; and the plants, when arranged, with a due regard to their habit on the different positions roek-work affords, will find themselves in sueh congenial situations, as to develope to the full all those luxurious and graeeful charaeteristics for which 
the Ferns are so much prized. The aecompanying vignette of Mr. Ward's Fern-house, shows something of the effect whieh is produced by plants disposed in this semi-natural way, although in this instance other plants are seen to accompany the Ferns.

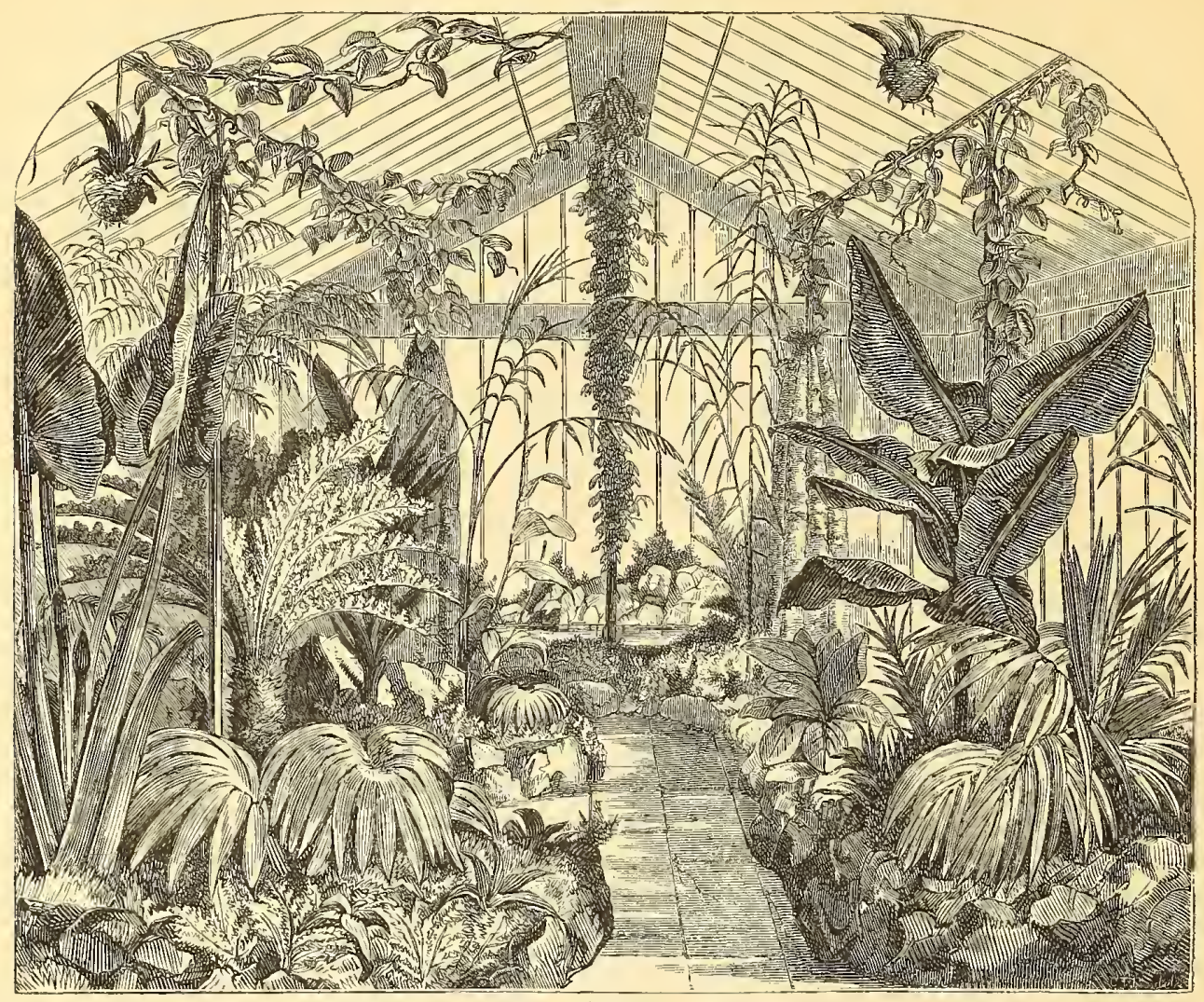

MR. WARD'S WERN-HOUSE.

Such a structure, as the accompanying figure represents, is in truth, a Wardian Case on a large scale, For all the greenhouse speeies nothing is better adapted than the modifications of the ordinary Wardian Case, of a size suitable to occupy convenient positions near the windows, in drawing roons, on stairease landings, and similar situations; or, if it be preferred, that modifieation of the Wardian Case to which the name of Warington Case is applied (in whieh aquatie botany and zoology is brought within the domestic range) may be adopted. The principle of the Warington Case is exemplified in the accompanying figure, whieh shows how, in some measure, the two objects may be eombined.

Wardian Cases are very easily managed. For the sake of durability the case should have a metallie box fitted within for the soil and roots; and this should have an outlet-to be elosed at pleasure-at the lower part communieating with the outside, by which all superfluous water may be drained off whenever water is applied. But for this it would be impossible to avoid the presence of stagnant water, whieh is most injurious to vegetation generally. Then a series of reversed flower-pots, and a layer of small lumps of old brick or freestone, from the size of an egg upwards, should be spread over the bottom, and on this six inches or more of the rongher turfy or lumpy parts of soil, well mixed with pure silver sand and smaller fragments of brick or burnt rlay, in the proportion of about one-third. The soil is to be placed on this foundation. It should eonsist of equal parts of good meliow maiden 
loam and light turfy peat, mixed with a third equal portion, consisting, bulk for bulk, of silver sand and of fragments of brick or soft sandstone of the size of nuts. This compost will suit any Fern, and with this the lower part of the ease is to be filled up. A few smallish lumps of sandstone, or of pumice-stone, should be employed to raise up some rocky elevation, according to faney, above the surfaee level; and the spaces between these stoncs are to be filled up firmly with the same kind of soil. The ease is then ready for planting; or, if the space is limited, it is better to plant as the piling up of the stones proceeds, because then the roots of the Ferns can be more readily disposed among

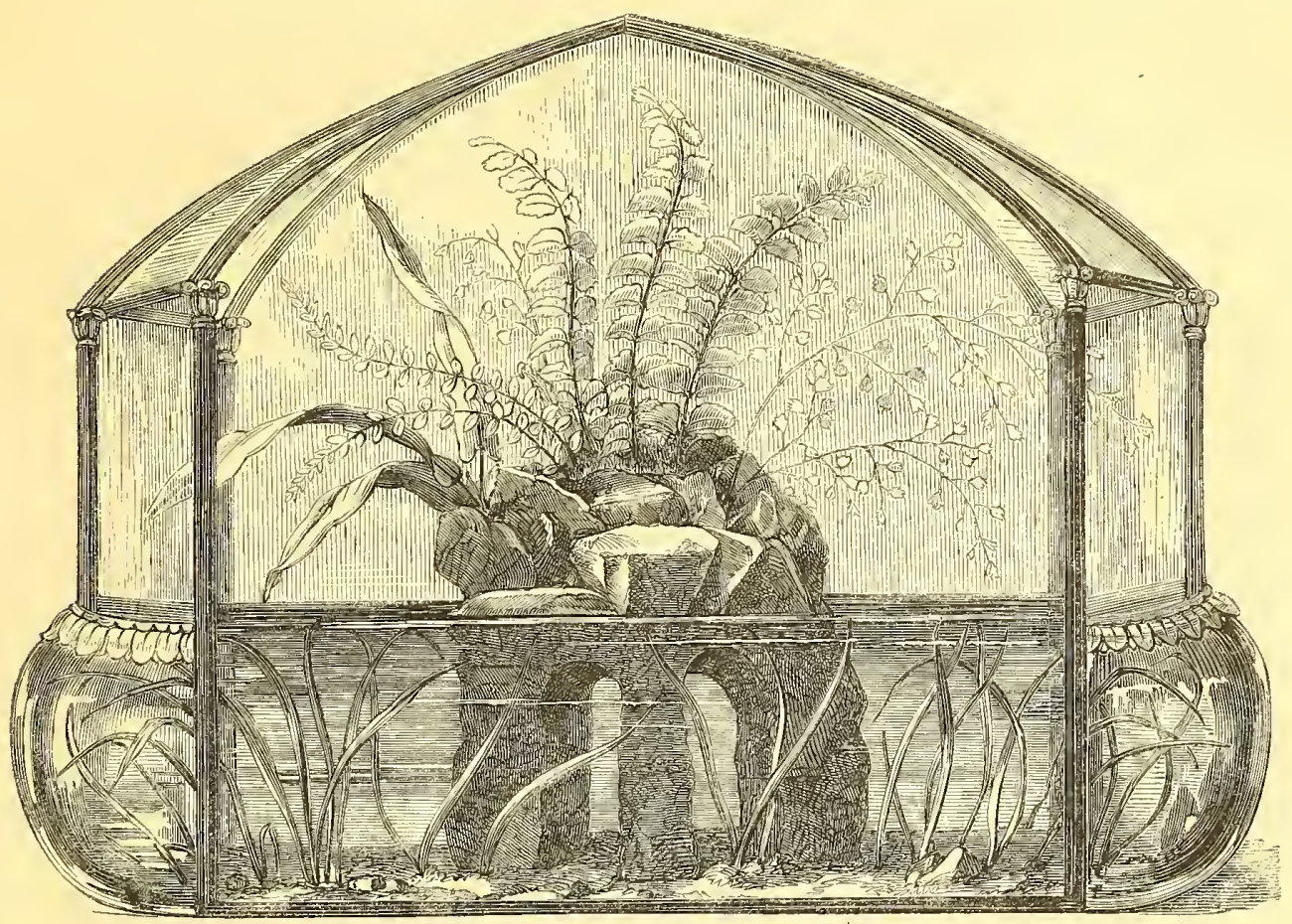

TIS W.ARINGTON PLANT CASE.

the soil. All species whieh grow naturally against rocks or trees should, however, rather be fixed firmly and compactly to the masses of stone, and, provided the atmosphere is made congenial to them, they will soon throw out their little rootlets, and fix themselves securely; whilst, if planted directly in the soil, some of them at least would fail to grow, and none would thrive so well.

After planting, a thorough watering should be giren; and all the superfluous water that will drain away in the course of threc or four hours should be allowed egress by the outlet at the bottom, which may then be closed until another watering takes place. Afterwards the case is to be elosed, and shonld remain so, exeept when it may be opened to view the plants; or, if any indications of mildew are observed, it may be opened for half an hour daily to check any sueh tendeney. If the aspect where they arc placed is not a shady one, artificial shading should be resorted to in all periods of bright sunshine. Under this treatment it will be some time--months perhaps, the period varying with the amount of moisture which is permitted to escape by evaporation-before another watering is needed; but when it is perceived that moisture is required, a thorough watering should be given as at first, allowing all that is superfluous to drain away before elosing up the case.

The necessary heat for structures devoted to Ferns cannot be better supplied than by the agency of a hot-water apparatus, constructed on a good principle; and in the case of tropical Ferns, a portion of the heating pipes should be so placed as to throw a degree of warmth about the stages on whieh 
the pots are placed. If this is not attended to, especially when the stages are of stone or slate, the quantity of water necessarily thrown ovcr them, in order to keep up the atmospheric moisture, is apt to produce an injurious chilliness about the roots, sometimes fatal to the more delicate kinds. The hardy species, as already mentioned, do uot require artificial heat. The greenhouse species merely require to be preserved from frost in winter, or, say in a temperature of $40^{\circ}$, increased to $50^{\circ}$ and $60^{\circ}$ in spring. For the stove species an average night temperature of $55^{\circ}$ to $60^{\circ}$, and day temperature of $65^{\circ}$ to $70^{\circ}$, is proper in the winter months; the temperature in the rest of the year averaging $65^{\circ}$ at night, and from $70^{\circ}$ to $80^{\circ}$ by day.

Of atmospheric moisture Ferus need an abundant and almost unvarying supply during the entire period of their growth; in fact, the atmosphere should almost constantly be kept at nearly the point of saturation. During the winter season, when all the higher groups of plauts are less active in their growth, the degrec of moisture may be properly limited, espeeially as it regards any kinds which may be of deciduous habit; but when growing Ferns are sought to be kept in health and vigour, the amount of moisture kept up must always be eonsiderable. This large amount of moisture being necessary, it is desirable to provide in Fern-houses a large amount of evaporating surface, composed of some porous material that will readily absorb moisture. It is a good plan to employ a false flooring of wooden trelliswork, so that the actual floor may be frequently flooded, without rendering the pathways inconveniently wet. Ferns slould also be lightly syringed twice daily, except during a continuanee of very dull weather: indeed, oftener in hot weather will be beneficial.

Though scarcely any Ferns thrive in a constantly wet soil, yet they are generally injured by being suffered to get dry at the root. Indeed, with some of the more fickle kinds this is certain destruction. During all the time they are growing, therefore, they should have a free supply of water at the root, taking eare that the soil never beeomes soddened. If this is scen to be the case, the plant should at onee be repotted, so that its drainage may be corrected. When the plants are dormant, less water is necessary.

The Watcr Fern (Ceratopteris thalietroides) is an exceptiou to the case just named. This, aftcr being potted, should be set in water of sufficient depth to cover the pot in which it is planted. Under these conditions, and supplied with a tropical temperature, it grows vigorously, producing abundance of sporules, from which it may be inereased. A simple mode of propagating this species, however, is afforded by the proliferous buds which are developed numerously on the old fronds. Young plants from this source should be secured towards the close of summer, and kept in small pots placed in feeders of water; and these, if shifted into fresh soil in spring, and set in warm water, will soon produce fertile fronds.

When Ferns are grown in pots, and have bccome well established, the majority of them like to have plenty of pot room, provided the pots are well drained. Thus a plant of a free-growing kind, bearing fronds of a foot or so in length, may have a pot nearly or quite a foot in diameter; and so in proportion to the size of the plants, provided always that excess is not indulged in, and that when any appearance of overpotting is observed it is speedily remedied.

Ferns are less attacked by insects than most other plants, but they are sometimes infested by one of the large species of coceus, which spreads rapidly, and if suffered to accumulate is very troublesome to remove, and renders the plants filthy and unsightly. Some of the tender-foliaged kinds are sometimes attacked by green-fly, which are to be destroyed, as soou as perceived, by fumigation with tobacco, which is also the best method of destroying the thrip, which is apt to infest the hardier sorts when they are placed in a high temperature, and, if too dry an atmosphere is maintained, sometimes spreads over a colleetion, and occasions much annoyance.

Ferns are propagated by division or by their spores. Some increase very readily, and others only with the greatest unwillingness. All the creeping-stemmed species are increased without difficulty, by detaching portions of the caudex or rhizome furnished with fronds and roots, aud placing them in a close frame, after potting them, until they are established. Some of the ferns of this habit, however, which prefer to adhere to the surface of damp stone, or the bark of wood ratler than to be potted in 
soil, such as Trichomanes and others, should have the portions of their rhizome firmly fixed against the stone or wood, and then must be kept elose and moist until they get established. The tufted-growing species, where they readily produce lateral crowns, are increased by dctaching these with their roots and potting them separately; but others of this habit so seldom produee any other than their central crown, and this indivisable, that it scareely ever becomes possible to increase them by this means. Many species are viviparous, and these are readily increased by fixing a frond in contact with the surface of the soil, and detaching the young plants after they have become rooted. A few others produce young plants at the apex of their fronds, thus affording a means ofincrease. But the most general mode of inerease is by means of the spores, which are the analogues of the seeds of flowering plants, and which are in most cases produced very abundantly. We quote the following account of their germination from Mr. Henfrey's paper on this subject in the Gardeners' Magazine of Botany (vol. iii., p. 22) :-

"It has long been known that when the spores of the Ferns germinate, they first produec little disks of green cellular tissue, lying like eolleetions of little green membranous seales upon the surfaee on whieh they are growing. A few years ago, Professor Nageli of Zurieh observed a peeuliar structure upon these little germinal fronds, eonsisting of eellular bodies, from which were discharged spiral filaments, moving rapidly and apparently voluntarily through the water in which the objeet lay beneath the mieroseope. The diseovery of these organs was not mueh notieed at the time, but subsequently Count Leszezye-Suminski of Berlin made a eomplete series of observations on the germination of the Ferns, and published an elaborate and fully-illustrated aecount of them, in whieh he not only eonfirmed the statement of the existenee of these so-ealled antheridia of the Ferns, but showed that there existed two kinds of eellular organs upon the young germ frond, whieh organs he eonsidered to represent the two sexes, and to eorrespond to the antheridia and pistillidia of the mosses.

"I have examined these struetures, and can eonfirm completely, in most respeets, the aeeount

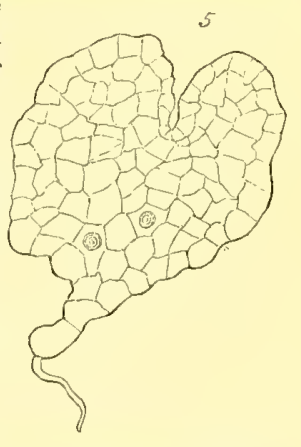

$1,2,3,4,5$. Successive stages of dcrclopment from the spore shown at Fig. 1. In Fig. 5 are scen two of the antheridia.

Suminski has given of their general strueture; but my observations have not yet been suffeiently extended to enable me to give an opinion on the physiologieal questions relating to them, whieh I shall presently speak of. In the first place, therefore, I will deseribe these bodies as I have seen them, and in a manner whieh will enable any one possessing a mieroseope to repeat them for himself.

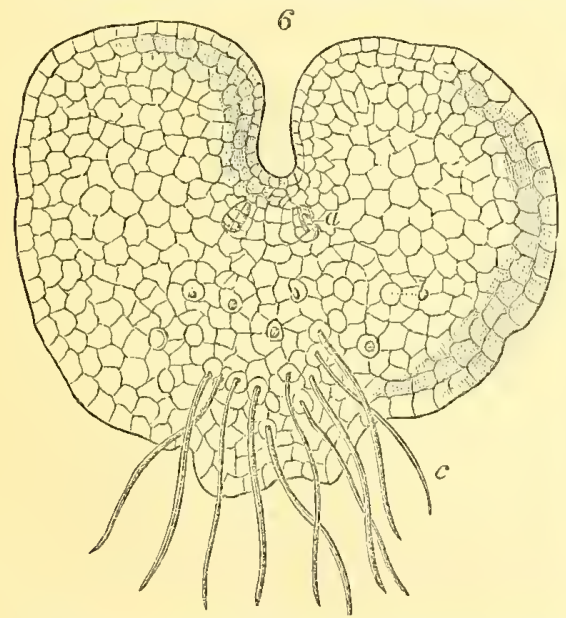

6. A germinal frond (it is a simple ccllular plate like the leaf of a Moss): $a$ are two "ovules;" $b$ a number of "antheridia;" c root fibrils.
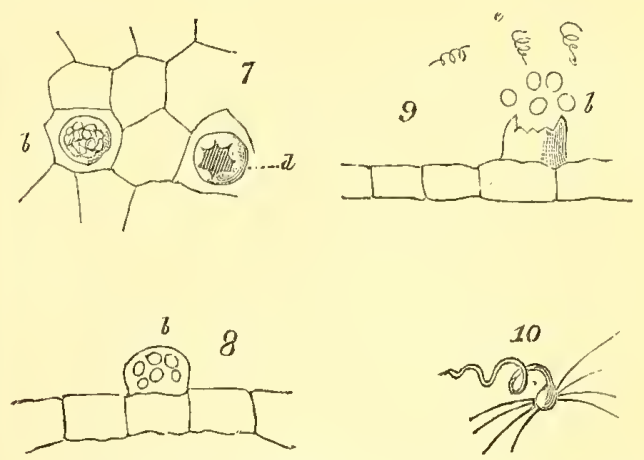

7. A more highly magnified view of a piccc of the frond with two "antheridia," one containing the vesicles $(b)$, the other burst $(d)$.

8. Side vicw of $b$ in the last figure.

9. The same bursting to discharge the vesicles, which again discharge the spiral filaments $e$.

10. One of the spiral filaments or "animalcules" more magnified.

"The germinal frond must be taken very young, while yet not more than one-eighth of an ineh in diameter, and before any sign of the first leaf appears rising from its upper surfaee. The little frond will then be found in the shape of a rounded or heart-shaped disk, formed of delieate green eells (Fig. 6); a single layer, except in 
the middle, having been gradually developed into this form through the stages represented in the preceding figures (Fig. 1-5). To see the peeuliar organs, the disc-like cellular plate must be carefully laid face downwards upon a slip of glass, and washed clean, gently removing the grains of soil with a camel-hair pencil from among the rootlets. When plaeed under the microscope, a number of projecting cells (Fig. 6, $b$ ) are generally found scattered about the frond. These are seen to be again filled with minute vesicles (Figs. 7 and 8 ), which eseape by the bursting of the protruding cell, either spontaneously or by slight pressure on the glass covering the object (Fig. 9). As the vesicles emerge they burst also, and from them springs out a spiral thread-like body, thickened at one end, and furnished with cilia (Fig. 10). These, the so-called animaleules, swim about

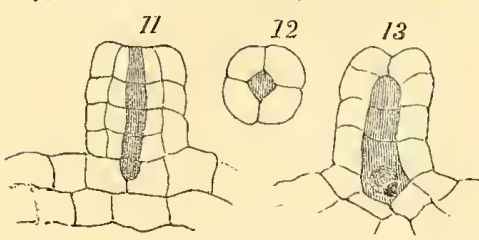

12. Side view of an "ovule."

13. The summit of the same, seen from above.

13. Side view of an "ovule" from Suminski, representing the embryo-cell at the bottom of the eavity. with great rapidity, shooting forward, and continually whirling round on their own axes. To see them clearly their motion must be stopped by adding a little solution of iodine. On the thickened part of the frond, near the noteh, are to be found in most cases, not always, cellular structures of larger size, and more complicated (Fig. $6, a)$. They consist of conical papillæ, with cellular walls, containing a cavity in the centre (Fig. 11-12.)

"Now, the statements of Suminsli are to the effect that these last bodies represent ovules, and that a little cell exists at the bottom of the cavity (Fig. 13), whieh becomes fertilized by the entrance of one of the spiral bodies, in a manner supposed to have some analogy to the entrance of the pollen-tube into the ovules of flowering plants. My own observations have not afforded me a view of any process of this kind; and elaborate investigations have been made since the publication of Suminski's paper by two skilful German anatomists, Dr. Wigand and M. Schacht, with a view to confirm or refute his assertions, so important in a physiological point of

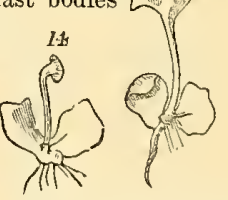

14, 15, 16. Germinating Ferns (Pteris serrulata), with the young leaves splinging up from the germinal frond.

view. They both agree in stating that very extensive research has failed to reveal anything like an entrance of the spiral bodies into the so-called ovules; and M. Schacht further avers, that in the young stages of the 'ovules,' at which stage Suminski states the fertilization takes place, the eavity is closed up."

The evidenee is so far against Count Suminski's views, though the probabilities are in favour of them; and, at all events, the import of the remarkable structures remains to be cleared up. The first leaf emerges from the substance of the cellular thickening of the germinal frond, which is carried up a little way in a kind of sheath. The "ovule," or several, may often be seen attached to the side of this sheathing process of tissue. It is the opinion of Count Suminski that the first leaf is developed from the minute cell which, he says, lies at the bottom of the "ovule," just as the embryo is in the embryo sac of a phanerogamous ovule; but, if this were the case, there would be the striking difference that the embryo bursts through the coats of the ovule at the side, the radical extremity not pointing to the canal where the fertilizing influcnee enters, as in the flowering plants. The second lcaf of the young plants is developed in the axil of the first, and so on, the little Marchantia-like germinal frond soon decaying away.

The spores germinate whenever they fall on a surface eonstantly damp, such as the surface of the soil, a damp wall, or the damp cxterior of a flower-pot. Self-sown plants spring up by thousands in houses where collections of Ferns are kept. When the object is to raise any particular kind, or to obtain living plants of new species from the spores derived from herbarium specimens, a very convenient plan is to fill a pot or pan with soil rather more loamy and sandy than that employed for potting, the pan being well drained. After giving the surface a good watering, scatter the spores evcnly over the surface, and set the pan under a close glass and in a close frame, aroiding watering if possible until they have germinated. When the second and third fronds are produced they can be handled, and should be transplanted into nursery pots, or otherwise as may be convenient. After they have reached this stage, their progress is rapid.

Another method of raising Ferns from the spores, much more exact in its results, has becn described by Mr. Deane, of Clapham, in the following interesting letter * addressed to Mr. Ward:- 
"When Suminsky's work on the development of Ferns first eame into my hands, a strong desire to repeat his observations led me to seek for scedlings where they were most likely to be found, namely, in my own Ferncase, at Kew, and other conservatories; but I soon found such sources were unsatisfactory, for, although I could obtain abundance of plants in which the organs of reproduction (?) described by him were clearly discernible, yet I could rarely find the moving ciliated bodies said to perform such an important part in their development. There were, too, differences, evidently specific, that I could not comprehend, and which were a bar to anything like correct observation. It was therefore obvious, if the investigation were to be followed up successfully, that some means must be devised for raising an unlimitcd supply of any desired species.

"The usual method of sowing Fern-seed, by scattering it over damp, sandy mould, is very uncertain, for the mould itself will frequently contain the seeds of other species; and even if the crop of plants come true to the sowing, it is difficult properly to separate sand and other extraneous matter from the young frond, previously to placing it under a microscope, without danger of injuring its delicate structure. My plan, therefore, was to procure some soft, porous, potter's ware-material that should readily imbibe and retain moisture-upon which to sow the seed desired to be raised. While searching for such material, I met with a peculiarly fine and soft sandstone admirably adapted for the purpose. This I prepared by breaking it into pieces of from one to two inches square and less than one inch thick, afterwards rendering the faces parallel and smooth by rubbing them on a flat stone. The reason for thus adjusting the size and smoothness of the pieces was simply to facilitate their being placed, for observation, on the stage of a microscope. Before sowing the sceds on these preparcd pieces, they were baked in an oven, to destroy any organic life that might be lurking about them. They were then piled in dishes, moistened with distilled water, and covered with bell-glasses, preparatory to receivlng the seed. The seed to be sown was obtained from a recently-gathered frond, laid fruiting side down, between two sheets of white paper, on the top of which was laid a book, or piece of board, to keep them in place. In the course of three or four days the seed was discharged from the capsules, and removed to the damp stone, by tuming the stone down upon it, of course taking carc tbat the seed did not lie too thickly. In about sixty hours germination had commenced, and henceforth daily progressed into maturity. In this way I have raised several species of Ferns without a failure; abundant means being thus afforded for observing their development from the commencement of germination up to the perfcct-plant.

"I have been repeatedly told by those who havo attempted to raise Fcrns from seed, that I might sow what I pleased, but something I did not want would spring up. Most likely such had been the experience of my informants, although the reason for it was not obvious. My cxperiments proved the contrary, and demonstrated most unequivocally that, by observing the requisite conditions, any species may be raised, if the seed sown be resh and fully matured.

"This principle of raising Ferns is applicable to several important purposes, besides that of the facility it affords for observing and studying the laws of their development. In the first place, many kinds now rare and valuable, or even unknown, in this country, from the difficulty of bringing them home, even with the protection of Mr. Ward's glazed cases, might bo introduced with facility by sowing the seeds in the country where they grow on some suitable material, whether sand-stone, Bath brick, tile, wood, bark, or even charcoal; wood or bark suggests itself in the case of such as are parasitic in thcir habits, and inclosing them in a small glass casea case so much smaller than would be required for full-grown plants that it migbt be a cabin companion for a long voyage. Secondly, it is frequently desirable, even in this country, to raise particular species with some greater degree of certainty than, from various ill-understood causes, is generally found practicable. Again, experiments on this principle may be tried in a great variety of ways, until the true habits of obscure species are accurately determined. Some Ferns are impatient of removal: such may be raised from seed on suitable pieces of stone or wood, and afterwards introduced into pots or creviccs in walls and rock-work prepared to receive them.

"I conceive that a Ward's case, artificially filled with such admirable sand-stone as my experiments have been made upon, but which I am sorry not to be able to tell you the source of, might be judiciously sown with seeds of small moisture-loving Ferns, and form one of the most exquisite of drawing-room or cottage conservatories, and which, in its gradual progress to maturity, would delight the eye, expand the understanding, and warm the heart in love and gratitude towards the Author of that portion of Creation which is truly the most beautiful, as well as most essential, to our healthy and happy existence on earth-I mean the vegetable kingdom.

"No kind of vegetation that I am acquainted with has ever struck me with such wonder, admiration, and delight, as the little crops of Ferns raised in the way I have now endeavoured to show; and nothing would please me better than to see others deriring similar enjoyment from this simple and accessible source. Any one who makes a garden of this kind under a bell-glass, must observe that the material on which the seed is sown is so porous that the requisite amount of moisture will pass to the top, by capillary action, when applied to the bottom of it; also, that with an abundance of light, the sun must not shine directly upon it." 


\title{
SXNOPSIS OF THE GENERA.
}

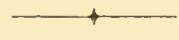

DOLYPODIACEA, R. Brown,-Spore-cases pedieellate (rarely sessile), with a vertieal (rarely oblique) elastie nearly eomplete ring.
\end{abstract}

Tribe I. POLYPODIEA, J. Smith.-Sori round, oblong, or lincar, without a special indusium. Sometimes the margins of the scgments of contracted fcrtile fronds are revolute, and simulating an indusium.

Section I. Orthophlebiew, J. Smith.-Veins all distinct or free.

1. Grammits, Swartz-V Veins simple or forked internal, the soriferous venule sometimes very short. Sori oval or oblong, oblique, lateral.

2. Polypodrun, Linnceus. - Veins simple, forked or pinnate. Sori circular, rarely oval or oblong, uniserial, solitary, or irregular ; sometimes immersed in a deep cyst, terminal or lateral.

3. StRUTHIopteris, Willdenow.-Fronds (fcrtile) with contracted conniving indusiiform margins to the moniliform pinnæ, the segments wholly occupied by round confluent sori; spore-cases lateral, the base of the pedicels concrete, and forming an clcvated thickencd receptacle. Teins pinnate.

4. Allosonus, Bernhardi-Veins forked, terminating within the indusiiform margin. Fronds dissimilar ; the fertile with contracted conniving indusiiform margins. Sori round or oblong; becoming conflucnt, terminal.

5. Мотноснцжла, R. Brown.-Veins forked, pinnate, or bifurcatc. Sori round, solitary or laterally confluent into a lincar continuous or interrupted marginal band, terminal.

6. Grmnogramma, Desvaux.-Veins forked or pinnate; vemules simple. Sori oblong or linear, simple or forked, oblique, often becoming confluent, medial; spore-eases superficial, often occupying nearly the whole length of the venules, and somctimes cchinate.

Section II. Symphophlebiex, J. Smith.-Veins anastomosing or reticulated.

7. Meniscium, Sehreber.-Veins pinnately costæform, the opposite pairs of venules angularly or arcuately anastomosing, and producing from their junction an excurrent sterile veinlet, which is frec or united with the venules above it. Sori lincar, somewhat transverse, arcuate or crescent-shaped, continued across the junction of two anastomosing venules, medial, at length conflnent.

8. Goniopteris, Presl. -Veins pinnately costæform, the lower (or more) opposite pair of venules angularly anastomosing, and producing from their junction a frec or anastomosed excurrent stcrile veinlet. Sori round, medial, or costal, sometimes cchinate. 
9. Goniopillebium, Presl.-Veins forked or pinnately eostreform, the lower exterior venule frec and fertile, the rest angularly anastomosing, and producing from their juuction an cxcurrent frec, often fertile, veinlet. Sori round, in one or morc transversc parallel rows, naked or squamifcrous, terminal.

10. Crrtophlebium, R. Brown.-Veins forked or pinnately costreform, the lowest exterior venule frce and fertile, the rest arcuately or angularly anastomosing, producing from their exterior side two or more excurrent frce, usually fcrtile veinlets, which arc sometimes very short, or sometimes united with the next superior venules, thus forming two series of areoles between each two primary veins. Sori round, naked, arranged in two rows betwcen and parallel with the costreform veins, or irregular, terminal, or lateral.

11. Nipнoвolus, Kaulfuss.-Teins internal, indistinet, pinnate; venules parallel, transversely anastomosing, producing from their exterior side two to five or morc free or irregularly anastomosing veinlets. Sori round, terminal, in parallel transverse rows between the veins, sometimes irregular and usually confluent, protruding through dense stellate pubescence.

12. Phlebodium, R. Brown-Veins pinnate or variously branched; venules arcuatcly or angularly anastomosing, produciug on their cxterior side or at their angular junction two or more conniving veinlets, whieh are sporangiferous on their combined apices or point of junction. Sori round, oval or rarely oblong-linear, transversely uniserial, biscrial or multiserial, sometimes irregular.

13. Drynaria, Bory.-Veins pinnate, parallel or flexuose; venules compoundly anastomosing, producing sori at the angles or points of conflucnce, and from their sides variously dirceted free sterile veinlets. Sori round or oblong, naked, or squamiferous, superficial or deeply immersed, uniserial, or in one or two oblique rows betwcen the veins, or irregular.

14. Dictymia, J. Smith.-Tenation uniform, reticulated, internal, the transversely uniserial sori compital, or produeed at the eonfluence of the venules; reeeptaele immersed. Sori large, oblong.

15. Drymoglossum, Presl.-Venation uniform, compoundly anastomosing, producing variously direeted frce veinlets. Sori linear, continuous, marginal or intramarginal, produeed on the transverse sides and junctions of the venules, forming a broad pilose or squamifcrous marginal soriferous line.

16. Teniopsis, $J$. Smith.-Veins simple, parallel, the apices combined transverscly by the rcceptacle. Sori linear, continuous, immersed in an intramarginal groove.

17. VitTARIA, Smith.-Veins simple, parallel, the apices combined transversely by the marginal receptacle. Sori linear, eoutinuous, immersed in a marginal groove faciug outwards.

18. Antrophyum, Kaulfuss.-Venation uniform, reticulated, the sides of the areoles more or less sporangiferous. Sori linear, continuous or interrupted, reticulated, the reeeptacle immersed in the substance of the frond.

19. Hemionitis, Linnaus.-Venation uniform, reticulated, the sides of the nearly equal areoles sporangiferous. Sori linear, reticulated, supcrficial, subsequently confluent.

20. Ceratopteris, Brongniart._Fronds dissimilar, flaccid. Veins transversely elongated, and distantly anastomosing. Sori linear, continuous, parallel, superficial, occupying the lengthened transverse sides of the venules, and coneealed by the reflexed conniving margins of the segments.

Tribe II. ACROSTICHEA, J. Smith.-Sori amorphous, that is, not of any definite form, without a special indusium.

Section I. Orthophlebier, J. Smith. - Veins all distinct or frce.

21. Elaphoglossum, Sehott.-Veins internal, simple, or forked; venules parallel, their apices clavate, terminating in a thickened margin. Sori dense, usually eovering the whole under surface of the fertile fronds, which are smaller than the sterile ones.

22. Stenochlana, J. Smith.-Fronds (fertile) contracted. Veins (sterile) simple or forked; venules parallel, their apiccs exserted forming cartilaginous scrratures, or conniving and forming a thickened margin. Sori densely covering the under side of the linear narrow pinnæ, whieh have membranous revolute margins. 
23. Polybotrya, Humboldt.-Fronds (fertile) eontraeted. Veins pinnate, simple; venules free, external, Sori occupying one or both sides of the spieiform segments of the contracted fronds.

Section II. Symphophlebiex, J. Smith.-Veins anastomosing or retieulated.

24. OlFErsia, Raddi.-Fronds (fertile) contracted and soriferous on both surfaces. Teins forked, parallel, internal, their apiees combined with a transverse continuous marginal vein. Sori dense, oeeupying the whole surface of the fertile fronds.

25. Anetiun, Splitgerber.-Teins uniform, reticulated, the areoles elongate trapezoid or hexagonal. Spore-eases sparingly scattered over the under surface, often collected into small groups or lines.

26. Hymenodium, Fee.-Fronds (fertile) contracted. Veins uniform, internal, reticulated, forming large elongated trapezoid hexagonal areoles. Sori densely covering the under surface of the fertile fronds. Rhizome decumbent, criniferous.

27. Acrostichum, Limens.-Fronds contracted in the fertile pinnæ. Veins uniform reticulated, forming small elongated usually tetragonal and parallel areoles. Sori densely covering the under surface of the fertile pinnæ. Rhizome erect, caudiciform.

28. Platycerium, Desvaux.-Fronds dissimilar, stellately pubescent, the fertile forked. Veins repeatedly forked and distantly anastomosing; venules internal, compoundly reticulated, with variously directed free veinlets terminating in the areoles. Sor $i$ forming irregular patehes near the extremities of the fronds or on special lateral thickened lobes; reeeptaele eonsisting of an accessory layer of parallel anastomosing veinlets erossing the sterile ones, and producing crowded linear lines of spore-cases.

29. Cyrtogonium, J. Smith.-Fronds (fertile) contracted. Veins pinnately costæform; venules arcuately or angularly anastomosing, producing from their exterior sides or points of confluence one or more excurrent free or irregularly anastomosing veinlets. Sori occupying the under surface of the fertile fronds, or erowded on the venules.

30. Gymnopteris, Bernhardi.-Fronds (fertile) contracted. Veins uniform or costæform; venules compoundly anastomosing, producing variously directed, straight or curved, free veinlets, terminating within the areoles. Sori universal on the under surface of the fertile fronds.

Tribe III. PTERIDE \&, J. Smith, -Sori round or elongated, transverse, marginal, intramarginal, or eostal, furnished with a special lateral indusium, free at the inner edge, and attached at the exterior side of the sporangiferous receptacle, which is parallel with the midrib or margin.

Section I. Chilosorece, J. Smith.-Sori marginal.

31. Adiantum, Linnaus.-Costa excentric or wanting; veins unilateral or -radiating, forked; venules direct, their apiccs terminating in the axis of the indusium. Sori round, reniform, oblong or linear, continuous or interrupted; indusium venose, sporangiferous on its under surfaee.

32. Cheilantries, Swartz-Vins forked; venules direct, their apices free and sporangiferous. Sori round, solitary or eontiguous, often becoming confluent; indusium usually reniform, rarely oblong, and including more than one sorus.

33. Hypolepis, Bernhardi.-Veins forked or pinnate, the lower exterior venule soriferous. Sori round, marginal opposite the sinus of the segments, partly concealed by a spurious indusium formed of a reflexed marginal erenule.

34. Platrloma, J. Smith.-Teins forked; venules direet, free, and sporangiferous at the apex. Sori oblong, laterally confluent into a broad marginal band; indusium narrow, attached to the outer side of the broad sporangiferous reeeptacle.

35. Doryopteris, J. Smith. - Veins nearly uniform, internal, reticulated, forming elongated oblique areoles. Sori linear, continuous; indusium narrow.

36. Liтов оспін, Presl.-Veins external, elevated, arcuately and angularly anastomosing, forming 
unequal arcoles, sometimes retieulated only near the midrib or margin. Sori linear, continuous, or interrupted; indusium narrow.

37. Lonchitis, Linncens.-Veins reticulated, producing unequal areoles. Sori oblong or lineararcuate, produced on the apiees of four or five convergent vcnules, which terminate in the sinus of the segments; indusium linear.

38. Pterts, Linncus. -Veins forked; venules free, or their apices combincd by a sporangifcrous receptacle; the inferior pair somctimes arcuatcly or transverscly anastomosing, forming a single row of elongated costal arcoles. Sori linear, continuous or interrupted, usually occupying the sides only of the segments; indusium plane, linear, its base often sporangifcrous.

39. Oxychiun, Kaulfuss.-Veins simple, direct, frec, or combined at their apices by a transverse sporangiferous receptacle seated in the axis of the indusium. Sori short, linear, continuous, usually bccoming confluent and covcring the whole of the segment; indusium plane, linear, slightly intramarginal, the free margins of opposite indusia conniving over the midrib.

Section II. Ifetasorea, J. Smith.-Sori intramarginal or costal.

40. Lomaria, Willdenow. - Fronds dissimilar, the fertile contracted. Veins (sterile) forked, scarcely evident in the fertile fronds; venules direct, frce, with club-shaped apices usually terminating within the margin. Sori linear, elongate, continuous, arising from a thick clevated reeptacle, often occupying ncarly the whole disk; indusium vaulted, revolute, and conniving, at lengtl replicate and torn, seated on or within the margin.

41. Blecindm, Linnaus._-Veins (sterile) forked; venules direct, free, in the fertile fronds combined near the base at the point of forking by a transverse sporangiferous receptacle. Sori lincar, continuous or interrupted, costal, rarcly medial; indusium plane, eonniving with the cosfa.

42. Doodia, R. Brown.-Veins forked; vemules arcuately anastomosing near the basc, there generally soriferous, then free and direct towards the margin. Sori oblong, straight or arcuate, transversely uniserial or biserial; indusium planc.

43. Woodwardia, Smith._Veins retieulated, becoming free ncar the margin. Sori oblong or linear, elongated, uniserial, immersed, produced on the transverse costal venules; ivdusium revolute, vaulted.

Tribe IV. ASPLENIE Æ, J. Smith.-Sori elongated oblique to the midrib or axis of venation borne on the supcrior or inferior'sides, or on both sides, of the venules, and furnished with a special lateral plane or vaulted indusium.

Section I. Orthophlebiea, J. Smith.-Veins all free.

44. Scolopendrium, Smith.-Veins forked; venules parallel, direct, free, with club-shaped apices, terninating within the margin. Sori lincar, unilateral, produced on the proximate sides of the anterior and posterior branch of each fascicle of veins, and confluent in pairs (face to faee); indusium (of each pair) with the free margins conniving, opening by a longitudinal suture.

45. Diplazium, Swartz.-Veins forked, or pinnate; venules direct, free. Sori linear, produced on both sides of the venules (back to back), constituting binate sori; indusium plane. All, or the lower vemules only, sorifcrous on both sides, the supcrior ones frequently producing simple sori, as in Asplenium.

46. Asplenidu, Linnceus.-Teins forked or pinnate; venules dircet, frce. Sori simple, linear, oblong, or elongated, unilateral on the anterior side of the venules; indusiun plane or vaulted.

Section II. Symphophlebiea, J. Smith.-Veins anastomosing or reticulated.

47. Ceterach, Willdenow. - Veins forked or pinnate; venules more or less anastomosing, the lower anterior one soriferous on the side next the raehes. Sori oblong or linear, unilateral, protruding through dense clongated scales; indusium obsolete. 
48. Neottopteris, J. Smith.-Veins forked; venules dircet, parallel, combined at the apices by a transverse continuous marginal vein. Sor $i$ linear parallel, unilateral on the antcrior side of the vcnules; indusium plane.

49. Antigramma, Presl.-Veins forked; vemules angularly anastomosing or reticulated, with the marginal veinlets free. Sori linear, unilateral on the proximate sides of the primary venules of each fascicle, usually confluent in pairs; indusium linear, the free margins of each pair conniving.

50. Hamidictrum, Presl.-Veins forked; venules parallel near the costa, anastomosing and reticulate near the margin, where they are combined by a transverse continuous vein. Sori linear, unilateral, on the anterior side of the parallel portion of the venules; indusium plane.

51. Callipteris, Bory.-Veins pinnately costæorm, the opposite pairs of venules angularly anastomosing, the superior ones usually free. Sori linear, binate, produced on both sides the venules; indusium plane.

Tribe V. ASPIDIEE, J. Smith.-Sori round, rarcly oblong, intramarginal, furnished with a special indusium, which is orbicular produced from the centre of the sporangiferous rcceptacle, or reniform or cucullate produced from its posterior side, or attached wholly round the receptacle (calyciform).

Section I. Symplophlebiea, J. Smith.-Veins anastomosing or reticulate.

52. Hypoderris, R. Brown.-Teins costreform; venules compoundly anastomosing, producing from their sides variously directed free sterile veinlets, and soriferous at the points of confluence of several veinlets. Sori small, irregular or uniserial on each side the veins; indusium small calyciform, very membranous, laciniate and fimbriate at the margin.

53. Aspidium, Swartz._Veins costroorm; venules compoundly anastomosing, producing from their sides variously directed free sterile reinlets, and soriferous on the points of confluence of several veinlets. Sori round, reniform, or by confluence oblong, irregular, or uniserial on each side the veins; indusium orbicular, peltate, or reniform, and attached laterally.

54. Sagenia, Presl.—Veins pinnate; venules arcuately or angularly anastomosing (compoundly anastomosing in the sterile fronds), forming unequal areoles with variously directed free veinlets on the apices of which the sori are most frequently borne. Sori reniform or orbicular, uniserial on each side the primary veins, or irregular, usually on the apices of free veinlets, sometimes on the points of conflucnce of two or more veinlets; indusium reniform or orbicular.

55. ONoclea, Linnceus.-Fronds dissimilar, the fertile with contracted bacciform sessile segments, with membranous conniving fimbriate margins forming an universal indusium. Veins (fertile fronds) simple direct free; or (sterile fronds) reticulated. Sori round, confluent, $4-8$ on each segment, medial, the pedicels of the spore-cases concrete; indusium (special) lateral, cucullate, very membranous.

56. Cyrtomiun, Presl.-Veins pinnate; venules, except the lower exterior one, which is free and fertile, angularly anastomosing, and producing from their exterior side or angular junction, 1-3 excurrent free fertile veinlets. Sori round, mcdial, numerous, transverscly multiserial; indusium orbicular, peltate.

57. Fadtenia, Hooker.-Fronds dissimilar, the fertile contracted, the sterile proliferous at its apex. Veins forked; venules anastomosing and reticulate, the lower anterior one in each fascicle frce and fertile at its apex. Sori large, roundish- or oblong-reniform, transversely uniserial in the costal areoles; indusium reniform, lateral.

58. Nephrodium, Sehott.- Veins pinnately-costæform; venules angularly anastomosing, the lower or more pairs producing from their junction an excurrent anastomosing veinlet, the superior ones free. Sori round, medial, uniscrial on each side the primary vcins, somctimes confluent; spore-cases sometimes echinate; indusium reniform, rarely orbicular. 
Section II. Orthophlebiea, J. Smith.-Veins all frec.

59. Woodsia, R. Brown.-Veins forked; venules simple. Sori round, termiual or medial, at first distinct, subsequently confluent; indusium calyciform, ncarly entire or deeply laciniated, the laciniæ usually terminating in long hairs which involve the spore-cases.

60. Cystopteris, Bernhardi--Veins forked; venules simple. Sori round, medial, often becoming conflucnt; indusium lateral, oblong, inflated, cucullate, attached beneath the sorus across the venule by its broad base, the free margin dentate or fimbriate.

61. Lastrea, Presl.--Veins forked or pinnately costæform; venules direct. Sori round, uniserial, medial, or terminal ; indusium lateral, reniform, rarely orbicular, glabrous or pilose, sometimes cochleate.

62. Pycnopteris, T. Moore.-Veins forked; venules elongate, parallel, direct, mostly terminating in club-shaped apices near the margin, the lowest anterior and posterior ones (sometimes more) in each fascicle soriferous. Sori large, roundish-reniform, medial, near the costa, irregularly bi-triserial; rcceptacle elevated; indusium reniform.

63. Polystichum, Schott.-Veins forked or pinnately-forked: venules direct, the lower anterior one more fertile. Sori round, medial, rarely terminal, uniserial ; indusium orbicular, peltate, rarely excentric and reniform.

64. Crclopletis, J. Smith.-Veins thrice dichotomously branched; venules direct, the lower anterior and posterior ones of each fascicle fertile. Sori round, medial or terminal, biserial ; indusium orbicnlar, peltate.-Pinnæ articulate.

65. Didymochlena, Desvaux.-Veins forked, radiating; venules direct, the apices of the sterile ones clavate, the anterior one fertile. Sori elliptical, terminal, uniserial; indusium oblong, longitudinally attached by its centre.-Pinnules articulate.

66. NePHRolePIs, Schott.—Veins forked; venules direct, the antcrior one soriferous. Sori round, terminal, uniserial; indusium reniform, sometimes almost orbicular.-Pinnæ articulate.

67. Oleandra, Cavanilles.-Veins simple or forked; venules parallel, direct, their apices curvcd, forming a slightly thickened margin. Sori round, costal or irregular, nniserial; indusium reniform, rarely orbicular.

Tribe VI. DICKSONIE $\mathbb{E}, J$. Smith.-Sori marginal, round, globose, vertically-oblong or transversely-elongate, with a special interior-attached lateral indusium, conniving more or less with the changed indusiiform margin of the froud, forming urceolate calyciform or two-lipped cysts, or marginal groores containing the spore-cases.

Section I. Lindsea, J. Smith.-Spore-cases pedicellate, from an elongated transversely anastomosing, rarely simple, terminal receptacle; indusia plane two-lipped.

68. Dictyoxipпium, Hooker,-Fronds dissimilar, the fertile contracted with revolute margins, sorifcrous on the upper half. Costa central, prominent; veins internal, nearly uniform, compoundlyanastomosing with variously directed free veinlets terminating in the areoles. Sor $i$ linear, continuous, occupying both margins; indusium linear, attached to the receptacle, opening from the upper surface of the frond, and becoming rolled back.

69. Linds жA, Dryander.-Costa excentric or wanting; veins forked radiating; venules (sterile fronds) direct frce; or (fertile fronds) combined at their apices by the transverse receptacle. Sori lincar, continuous rarely interrupted; special indusium linear, continuous, usually shorter than the indusiiform margin of the frond.

Section II. Davalliea, J. Smith.-Spore-cases pedicellate from a simple terminal receptacle; indusium more or less attached by its base and sides, rarely by its base only, equalling the margin of frond and forming an urceolate two-lipped or tubular vertical cyst.

70. Leucostegia, Presl.-Veins forked; venules direct, free. Sori round, terminal, often solitary on each segment, scated in the sinus; indusium scariose, orbicular or oblong, its sides free. 
71. Microlepia, Presl.-Veins forked or pinnate; venules direct, free. Sori round or oblong, vertical, superficial, intramarginal; receptacle elevated; spore-cases spreading, rarely immersed in a cystiform cavity; indusium attached by its base and sides widening upwards, the free margin rounded or truneate.

72. Deparia, Hooker.-Veins pinnate; vemules simple, direct, their apices free and sporangiferous. Sori globose, extra-marginal; spore-cases pedieellate, vertical; the indusia forming with the indusiiform teeth, calyciform exserted cysts.

73. Davaluin, Smith.-Veins forked; venules direct, free, with their apices soriferous. Sori vertically oblong, intramarginal ; spore-cases pedicellate, exserted bejond the free margin of the indusium; indusium inflated, forming with the changed margin of frond, a vertical two-lipped or tubular cyst with the apex usually constricted.

Scction III. Trichomanea, J. Smith.-Spore-cases sessile, seated compactly around a columnar receptacle, included within a bilabiate or urceolate usually vertical cyst, formed by the connivance of the indusium with the margin of the frond.

74. Trichomanes, Lnneus.-Veins simple or forked, direet. Sori vertically oblong, terminal; spore-cases sessile; receptacle filiform exserted; indusium urceolate or caljciform.

75. Hymenophyllum, Smith.-Teins direct, free. Sori globose or vertically oblong; spore-cases sessile; receptacle eolumnar included; indusium urceolately two-lipped.

Section IV. Dicksoniece, J. Smith.-Spore-cases pedicellate from a round terminal receptaclè, includcd within a concave two-lipped or calyciform reflexed eyst, formed by the connivance of the special indusium with the indusiiform crenules of the frond.

76. Siтовоцium, Desvaux.-Teins pinnate; venules simple or forked, direct, their apices free and sporangiferous. Sori globose, exserted; receptaclc elevated, globose; special and accessory indusia nearly equal, forming a reflexed entire or two-lipped calyciform cyst.

77. Balantium, Kaulfuss.-Veins pinnate; venules simple or forked, direct, free. Sori large, nearly globose, exserted, solitary on each segment; reeeptacle elevated, oblong; spccial and accessory indusia coriaceous, nearly equal, forming slightly reflexed oblong transversely two-lipped cysts.

78. Dicksonia, L'Heritier.-Teins pinnate; venules simple, direct, free, soriferous at the apex. Sori large, globose; receptacle elevated, globose ; indusia coriaeeous, the accessory cucullate, larger than the special, forming with it a reflexed unequal two-lipped cyst.

79. Ciвorium, Kaulfuss.-Veins forked or pinnate; venules direet, free, soriferous at the apex. Sori somewhat globose, superficial, seated on the interior edge of the margin or sinus; receptacle small ; indusium coriaceous, of two unequal valves, forming a reflexed adnate two-lipped cucullate cyst.

Tribe VII. CYATHE $E, J$. Smith.-Sori round, globose, intramarginal, medial or axillary, furnished (generally) with a calyciform or lateral interior-attached special indusium, or naked, or furnished with articulate hairs involving the spore-eases. Receptacle elevated, globose, or columnar. Spore cases usually sessile and compressed.

80. Cyathea, Smith.-Vins pinnately-costæform; venules forked, direct, free. Sori medial or eostal, uniserial, usually axillary in the forks of the veins; sporc-cases compressed, seated on a globose receptacle; indusium inferior, with an operculiform apex, becoming calyciform, entire or unequally lacerated.

81. Hemitelia, R. Brown.-Teins simply or pinnately-forked; venules free, or the inferior ones angularly anastomosing, forming a costal arch and other areoles between the sinus and midrib of the segments. Sori medial, uniserial, submarginal, or irregular; receptacle globose; indusium semicalyciform, interiorly attached.

82. Alsophila, R. Brown.--Teins pinnately costæform; vonules simple or forked, direet, free. Sori round or sub-globose, sometimes becoming confluent, medial or axillary, naked or furnished with a lateral interior indusium, which is sometimes very small or hair-like. 
GLEICHENIACEA, R. Brown.-Sporc-cases scssile, globose or pyriform, opening vcrtieally, with a complete transverse ring. Soriround, superfieial or immersed.

83. Gleichenia, Smith.-Tcins pinnate or pinnately forked; venules free, the lower anterior one fertile. Sor $i$ round, terminal, naked and superfieial, or immersed in a eoneave cyst; spore-eases 2-4,

84. Mertensia, Willdenow. - Teins simply or pinnately forked; venules direet free, the anterior one fertile. Sori round or globose, medial, naked or intermixed with hairs, superfieial; spore-cases $3-8$.

SCHIZAEACEA, Martius.-Spore-eascs sessile, oval oblong, rarely globose, striate or rayed at the apex, opening lengthways (vcrtieally) on the extcrior side, produeed on eontracted marginal lobules or speeial appendiees to the fronds.

85. Lygodium, Swartz.-Veins (sterile) forked, free, or (fertile) pinnate; venules arcuate, bearing the spore-eases on their superior sides. Sor $i$ on marginal appendiees, forming linear spikelets, eomposed of two series of indusiate imbrieating eysts, eaeh of whieh eontains an oval resnpinate sporeease attaehed by its interior side.

86. Lygodictron, J. Smith.-Tcins (sterile) pinnate; venules anastomosing, forming unequal oblong areoles. Sori on marginal appendiees, forming linear spikelets, eomposed of two rows of indusiate imbrieating eysts, eaeh of whieh eontains an oval resupinate spore-ease attached by its interior side.

87. Schizex, Swartz.-Fertilc appondiees terminal, forming a reflexed pinnate erest of linear segments, whieh have an inflexed indusiiform margin. Spore-cases oval, vertieal, arranged in a eompaet row on eaeh side the midrib of the linear unilateral eonniving segments.

88. Anermia, Swartz.-Veins forked; venules direet, free. Fertile fronds tripartite, the two opposite branehes contraeted ereet. Sori unilateral on linear segments, forming dense eompound panieles ; spore-cases oval, vertieal, naked.

89. Aneimidictron, J. Smith.-Veins forlked; vcnules reticulated, forming unequal oblong areoles; otherwise as Aneimia.

90. MoHria, Swartz.-Fronds dissimilar, the fertile ereet, uniformly eontraeted, eonstituting a raehiform unilateral sporangiferous paniele, with the margin of the segments inflexed. Veins forked; venules direet, free. Sori marginal, on or near the apices of the venules; spore-eases ovate, globose, naked.

OSMUNDACE E, Martius.-Sporc-cases pcdieellatc, globose, retieulated, opening by a vertieal slit (bivalved), the apex oblique, gibbous, pellueid, destitute of a ring.

91. Osmunda, Linncus.-Veins forked; venules direct, free. Sor $i$ naked and densely elustered on eontraeted fronds, or on some portion of the segments, whiel are eontraeted, raehiform, simple or paniculate; sporc-eases large, subglobose.

92. Todea, Willdenow.-Veins simple or forked; venulcs direet, free. Sori oblong, simple, or forked, and subsequently eonfluent; spore-eases naked, subglobose, bivalved, produeed on evident venules, few to eaeh sorus.

MARATTIACE E, Kaulfuss._Spore-cases sessile (rarely pedicellate), horny, opaque, distinct, and unitoeular, or laterally and oppositely eomate, forming a multitoeular round, oblong, or linear biserial or bivalved eompound spore-case, opening by pores or vertieal slits on the interior side.

93. Marattia, Smith.-Ieins forked; venules direet, free, Sor $i$ linear, submarginal, eonsisting of a transverse row of large oblong opaque multiloeular spore-cases, one on eaeh vein; spore-cases sessile, 
distinct, subtcrminal, longitudinally two-valved, the valves laterally connatc, containing 6-12 cells, opening by a vertical internal slit; rcceptacle subterminal.

94. Eupodium, J. Smith.-Vcins simple or forked, vcnules direct, free. Spore-cases large, oblong, multilocular, seated on slender stalks, longitudinally two-valved, the valves laterally connate, containing 5-8 cells opening by a vertical slit inside; receptacle medial.

95. ANGIOPTERIS, Hoffman.-Veins simple or forked ; venules direct, free. Sori linear, continuous, compound; spore-cases obovate, emarginate, sessile, laterally confluent, arranged in opposite serics of $5-7$ cells, the cells opening by a vertical internal slit; rcceptacle medial.

96. DANגA, Smith.-Teins forked; venules direct, parallel, areuate on their apices, anastomosing with the cartilaginous margin. Spore-cases linear, biserial, multilocular, each cell opening by a circular pore; receptacle occupying the whole length of the venules.-Fertile fronds usually contractcd.

OPHIOGLOSSACEA, Presl.-Spore-cases sessile, roundish or subglobosc, opening by a transversc fissure (bivalved), opaque, without a ring or reticulation.

97. Botrychium, Swartz.-Fronds two-branched, the fertile branch erect, contracted, constituting a compound sporangiferous unilateral panicle. Veins simple or forked, radiating; venules direct, free. Spore-cascs globose, distinct.

98. OpHioglossum, Linnaus.-Fronds two-branched, the sterile portion spreading, usually shorter than the crect fertile spike. Veins (sterile) uniform, reticulated, forming elongated areoles. Sporecases roundish, connate in two parallel rows into a simple compact spikc.

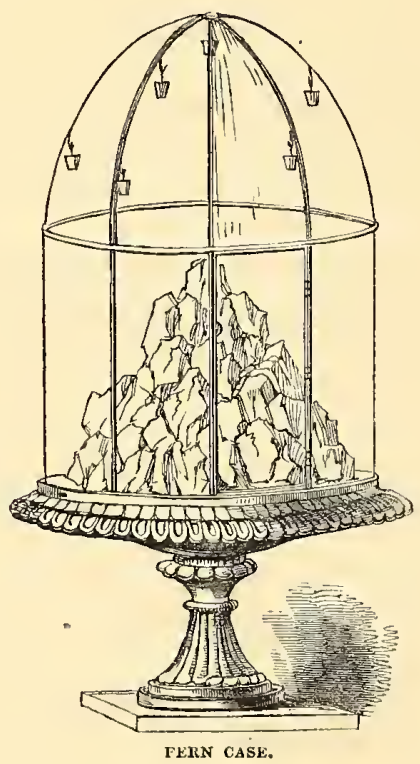




\title{
GENERA AND SPECIES OF CULTIVATED FERNS.
}

\author{
Order, POLYPODIACE 出, R. BRown.
}

Tribe, Polypodex, J. Smith-Sori of definite form, naked, i.e. without an indusium.

\begin{abstract}
Sect. Orthophlebiex, $J$. Smith (from orthos, straight, and phleps, a vein).-Wvins simple or forked, free, that is, not united so as to form a network.
\end{abstract}

\section{GRAMMITIS, Swartz.}

Sori oval, oblong, oblique; spore-cases lateral. Veins simple or forked, internal, the soriferous venule sometimes very short. Fronds simple, linear, with entire or serrulate margins, plane or convex at the apex.-Name derived from gramme, a line; alluding to the lines of sori.

This genus has considerable affinity with the \$eptogramma of Gymnogramma, in consequenee of its lincar-oblique sori ; but it is distinguished by its dwarf habit, simple fronds, and more simple venation. There are several species known; but one only has hitherto been introdueed in a living state. Fig. 1 represents the upper portion of a frond of Grammitis Billardieri (nat. size).

1. G. Billardieri, Willdenow (G. australis, R. Brown).-An interesting evergreen greenhouse speeies, from New Holland. Fronds simple linear-lanceolate aeuminate, from four to six inches long, light green, attenuated at the base. Sori linear-oblique, eonfined to the upper portion of the frond, oeeupying the whole of the venules. Stipes hairy; terminal, adherent to a tufted rhizome.

\section{POLYPODIUM, Linnaus.}

Sori eircular, rarely oval or oblong, naked, transverse, uniserial, solitary or irregular; sporc-cases terminal or lateral, sometimes seated in a deep cyst or cavity forming elevated

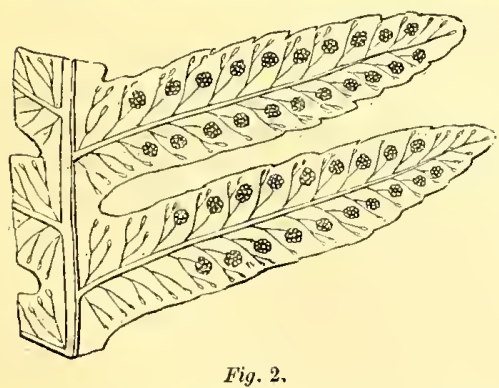

Fig. 2.

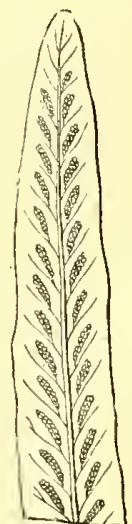

Fig. 1 protuberanees ou the upper surface of fronds. Veins simple, forked or pinnate, free. Fronds varying from a few inches to four or five feet high, and from simple to decompound; coriaceous, membranous, glabrous, villose or glandulose.-Name derived from polys, many, and pous, a foot; the creeping rhizome having many foot-like divisions or tubercles.

This genus, before it was divested of those possessing a retieulated venation, included between 200 and 300 species, presenting wide differences in habit and texture and in the circumscription of their fronds, which are now distributed among nine genera. The true Polypodiums have naked cireular (rarely oblong) sori, with simple forked or pinnate free veins. Fig. 2 represents a portion of Polypotium vulgare (nat. size). 
3. Cteonpteris, Blume,-Fronds articulated with the creeping rhizome.

1. P. vulgare, Limneus.-A hardy ornamental evergreen, indigenous Fern, * common in Europe, Asia, and North America. Fronds glabrous pinnatifid, onc foot high, dark green ; segments lanccolate, approximate, obtuse at the apex, with a crenulate or serrulate margin. Sori confined to the upper portion of the frond, arranged in a single row on each side of the midrib of the lobes (uniserial); spore-cases attached to the apex of an excurrent venule (terminal); apices of veins club-shaped. Stipes lateral, articulated with a creeping scaly rhizomc.

Several forms of the common Polypody are found with the segments morc or less pinnatifid, lobed, crenate, serrate, or bifid at the apex; but two or more of these may often be detected growing on the same plant. The only form that appears to maintain a markedly distinct character is $P$. cambricum, Linnæus, the segments of which are deeply and interruptedly pinnatifid. It is very elegant, but usually without fructifieation.

2. P. macrocarf um, Presl. (Goniophlebium, J. Smith; Pleopeltis pinnatifida, Hooker and Greville).-A dwarf evergreen stove Fern, native of South America. Fronds four to eight inches high, ovate, dark green above, and covered over beneath with distinct ovate caudate scales, which are black in the centre, brown, and deeply fringed on the margin. The fronds are pinnatifid, with oblong obtuse segments, and they are articulated on a scaly creeping rhizome. Sori large, uniserial. We have only seen sterilc fronds of the cultivated plant, but it appears to be identical with the species to which we have referred it, and from which our description of its size and fructification are drawn. It is a true Polypodium, the venation being free.

3. P. incanum, Swatz (Goniophlebium, J. Sith; P. velatum, Schkuhr).-A dwarf evergreen stove fern, native of the West Indies, various parts of South America, and Natal. Fronds pinnatifid, six to twelve inches long, lanceolate; segments oblong-obtuse, coriaccous, the upper surface dull green, densely covered beneath with roundish fimbriate peltate brown scales; they are lateral, articulated on a scaly creeping rhizomc. Sori immersed, sub-marginal, uniserial. Veins internal and indistinctly seen, but they are free, and it is conscquently a true Polypodium.

4. P. Plumula, Humboldt.-An excecdingly beautiful evergreen stove species, from the Wcst Indies and South America. Fronds lanceolate, sub-pinnate, from six inches to a foot or more long, grass green, with numerous linear, parallel, horizontal segments, thinly scattered over the under side with very small scales. Sori uniserial on the upper portion of the frond. Rachis and stipes ebeneous, scaly beneath; lateral, articulated, with a small crecping rhizome.

5. P. Otites, Limnaus (P. Pectinatun, of gardens-fide Kunze).-A very beautiful evergreen stove Fern, native of the West Indies. Fronds slender, sub-pinnate, from one to one and a half foot long, pubescent; the pinnæ linear, parallel, horizontal. Stipes and rachis black. Sori uniserial, of a bright yellowish-brown, distributed over the whole under surface. Fronds lateral, articulated on a creeping rhizome.

6. P. Paranisex, Langsdorf and Fischer (P. Otites of gardens).-A vely handsome evergreen stove specics, from Brazil and the West Indies. Fronds pubescent, from two to fivc feet long, very slender, lanceolate-elongate, narrowing to the base, sub-pinnate, the segments linear, nearly horizontal; the stipes and rachis blackishbrown. Sori uniserial, occurring over nearly the whole frond. Stipes very short; lateral, articulated on a creeping rhizome.

7. P. fraternum, Schlechtendal (P. Henchmanni, J. Smith MSS).-A glabrous evergreen stove Fern, from Mexico. Fronds oblong, acuminate, two feet long, quite smooth, pinnate, with long, linear-lanceolate, narrow pinnæ, decurrent at the base, very dark green; lateral, articulated, on a scaly creeping rhizome. Sori large, uniserial, bright brown.

Phegopteris, Presl.-Fronds adherent to the rhizome.

8. P. PHEgopteris, Linnaus. - $\mathbf{A}$ deciduous hardy indigenous species, found in most European countries, as far north as Lapland. Fronds pinnato-pinnatifid, from six to twelve inches long, the lower pinnæ standing forward, deflexed, with linear-lanceolate, entire segments, the upper ones adnate-decurrent. Sori rather oblong; intramarginal. Fronds lateral, adherent on a somewhat scaly creeping rhizome.

9. P. hexagonoptervim, Michaux.-A very handsome hardy deciduous Fern, from North America. Fronds triangular, about one and a half foot long, rather hairy, bipinnatifid; pinnæ opposite, scssile, decurrent at the basc, with oblong-obtusc crenulate segments. Sori sub-marginal. Stipes lateral, adherent to a creeping rhizome.

10. P. Dryopter1s, Linnaus.-A deciduous hardy British speeies; also found throughout Europe, Northern Asia, and North America. Fronds six to ten inches high, lateral, adherent to a creeping rhizome; they are ternate, deltoid, smooth, bipinnate, with deflexed spreading äivisions, and obtuse, subcrenated segments. Sori rather oblong, intramarginal.

11. P. Robertianum, Hoffman (P. calcareum, Smith).-A hardy deciduous British Fern, found in other parts of central Europe. Fronds from six to twelve inches high, erect and rather rigid, lateral, adherent to a rough scaly creeping rhizome; triangular, elongatc, threc-branched, the branches doubly pinnate, with somcwhat crenated obtuse segments. Sori round, intramarginal. Veins simple, occasionally forked.

* For more ample descriptions and figures of the British species, sce Handbook of British Fcrns. London : Groombridge. 


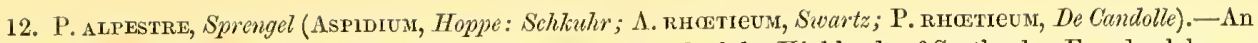
ornamental, hardy, deciduous Fern; native of Switzerland, and of the Highlands of Scotland. Fronds glabrous, lanceolate, one to three feet long, bipinuate, with lanceolate-acuminate pinnæ; the pinnules distinct, pinnatifid, oblong. Sori medial, round and uniscrial. Stipes short, terminal, adherent to a short decumbent rhizome.

13. P. Drepanum, Lowe (Aspidium, Swartz; Polystiehum, Presl).-An ornamental evergreen warm grecnhouse species, from Madeira. Fronds ovate acuminate, one and a half to two feet long, bipinnate, dark green; pinnx four to six inches long; pinnules lanceolate, falcate, auriculate, pinnatifid, inferior ones distant, cuneate at the base, superior basal ones longest, uppermost ones confluent, the segments all acutely toothed. Rachis and stipes paleaceous; terminal, adherent to a fasciculate erect rhizome. This plant has been placed in Aspidiece by most authors; and we had adopted this view in the Gardener's Magazine of Botany (iii. 320); but having since had an opportunity of examining the sori in its earliest stages, we have now no hesitation in referring it back to Polypotizm, it being entirely destitute of an indusium.

14. P. EFrusui, Swartz.-An evergreen stove Fern, from Jamaica. Fronds deltoid, membranous, three to five feet long, glabrous, pale green; four times pinnate, with lanceolate pinnæ; the pinnules linear-lanccolate, with pinnatifid segments, the lower one distant. Sori round, medial; veins pinnately forked. Stipes scaly, espccially near the base, adherent to a short creeping rhizome.

15. P. amplum, Humboldt (P. Lachnopodium, J. Smith-fide $K l o t z s c h$ ).-A very ornamental stove species, from Jamaica. Fronds deltoid, of a soft delicate texture, from two to four feet long, bi-tripinnatifid, with lanceolateacuminate pinnules, and oblong-linear, obtuse, hairy segments. Sori round, medial. Stipes and rachis densely covered with narrow brown scales. The fronds are terminal, adherent around an erect (caudiciform) rhizome.

16. P. rugulosum, Labillardière (Hrpolepis rugulosa, J. Smith; H. AMauroraehls, Hooker; Cheilanthes amadrorachis, Irtnze).- A rambling-growing evergreen greenhouse species, native of New Holland, New Zealand, and the Island of Tristan d'Acunha. Fronds triangular elongate, from two to four feet high, tripinnate, pinn $x$ lanceolate, with lanceolate-acuminate pinnules, and oblong, rather obtuse segments, the lower ones distant and pinnatifid, margin slightly crenulated. Sori round, sub-marginal. Fronds covered with glandulous hairs, lateral, adherent to a very peculiar, elongated, rough, crceping rhizome. Rachis and stipes purplish.

\section{STRUTHIOPTERIS, Villdenow.}

Sori round, eonfluent, wholly oeeupying the under surfaee of the segments; spore-cases lateral; base of the pedieels eonerete, forming an elevated, thiekened reeeptaele. Veins pinnate, free. Fronds of two kinds-fertile, with eontraeted, revolute margins, forming a spurious universal indusium; the pinne linear, revolute, moniliform, eaeh segment produeing five soriferous veins, the margin beeoming replieate and lacerated, and wholly oeeupied by round eonfluent sori--Name derived from struthios, an ostrich, and pteris, a fern; in allusion to the resemblanee of the fronds to ostrieh-feathers.

The habit of this genus, more than any technieal eharaeter, separates it from Polypodium. Fig. 3 represents a pinnule of the sterile, and a portion of the fertile frond of Struthiopteris pennsylvanica (nat. size.)

1. S. germaniea, Willdenow (Osmunda Struthiopteris, Limnaus) $\Lambda$ hardy deciduous ornamental Fern, from the south of Furope. Sterile fronds arranged in an exterior circle, reclining, from two to three feet long, lanceolate, pinnate, with pinnatifid-acuminate pinnæ. Fertile fronds few, occupying the centre, erect, about a foot long, dark brown, and resembling a bunch of feathers; they are contracted, pinnate, the pinnæ crowded, linear, revolute, and moniliform. Sori round, confluent. Fronds terminal, adherent to an erect (caudiciform) rhizome.

2. S. Pennsylvanica, Willdenow (ONoclea nodulosa, Schkuhr).--A hardy deciduous ornamental species, from North America. The sterile fronds commonly attain the height of two feet, and are lanceolatc, pinnate, the pinnæ acuminate, pinnatifid, with rounded blunt segments. The fertile ones are about a foot long, contractcd, pinnate, with linear, crowded pinnæ, which are revolute and moniliform. Sori round, confluent. Rhizone erect; fronds adherent.

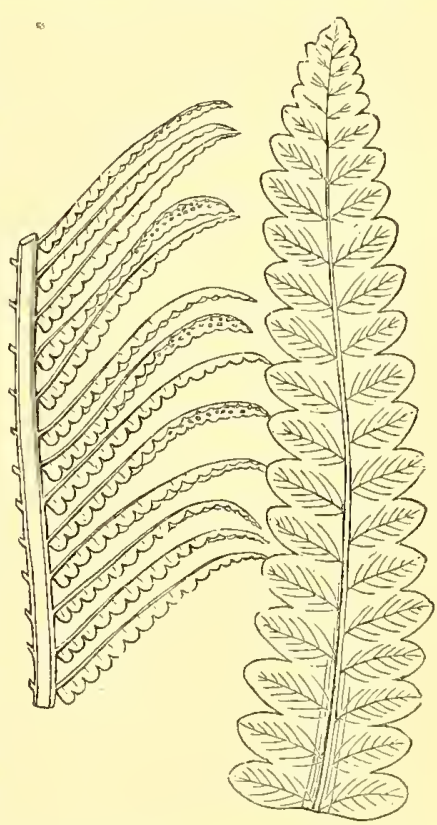

Fig. 3. 


\section{ALLOSORUS, Bernhardi.}

Sori round or oblong, becoming confluent, and ultimately occupying the whole under-surface of the segments; spore-cases attached on or near the apcx of the veins, forming broad, intramarginal, compound, transverse sori, concealed by the revolute margin of the pinnules. Veins forked, free, clevated,

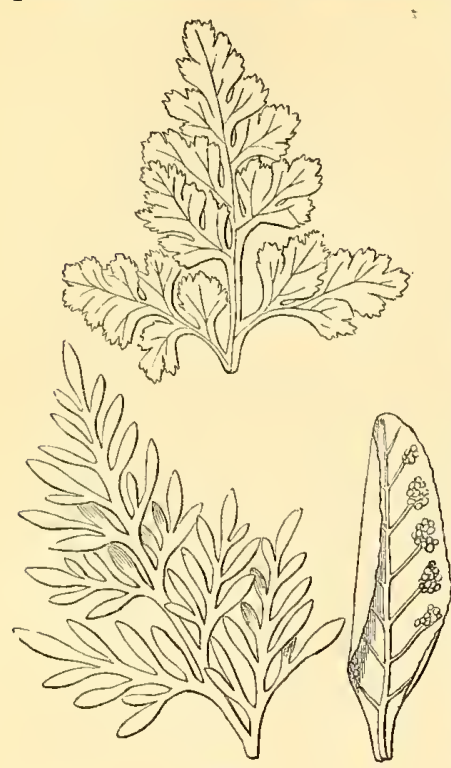

Fig. 4. terminating within the indusiiform margin. Fronds of two kindssterile, bi-tripinnate, generally smooth, with the pinnulcs dentate, crenate, or laciniate; fertile, contracted, segments oval or oblong, clliptical, revolute, and plaited.-Name derived from allos, various, and soros, a heap; in allusion to the altered appearances presented by the sori during the different stages of their development.

Fig. 4 represents the upper portion of a stcrile, and upper portion of a fertile frond (nat. size); and a segment of fertile frond (magn.), showing the veins and sori of Allosorus crispus.

1. A. crispus, Bernhardi (Osmunda, Linneus; Pнововодus, Desvaux; Pteris, Linnous ; Cryptogramma, R. Brown).-A very elegant dwarf hardy Fern, native of Britain, and the Alps of Europe. Sterile fronds bipinnate; pinnules bi-tripinnatifid, segments oblong, often bi-dentate. Fertile fronds contracted, bipinnate, tripinnate below; pinnules linearoblong, rather obtuse, revolute, entire, narrow at the base. Sori round, intramarginal, subsequently eonfluent, eoneealed by the revolute margin of the frond. Veins simple, forked where they are soriferous. Fronds triangular, from three to six inehes high, adherent to a deeumbent tufted rhizome. There are two or three distinet-looking forms of this plant oeeasionally met with; but they are not suffieiently eonstant to be eonsidered as permanent varieties. Several speeies of Platyloma are referred to this genus by some authors.

\section{NOTHOCHLÆNA, R. Brown.}

Sori round, solitary, subsequently confluent; spore-cases terminal, attached on or near the apex of the venules, forming a linear, continuous or interrupted marginal line. Veins forked, frec, pinnate or bifurcate. Fronds varying from pinnate to bi-tripinnate, hairy, densely scaly, woolly, or covered with a farinosc powder, through which the spore-cases protrude; of the latter there are usually but few to each sorus; margin somewhat slightly reflexed.-Name derived from nothos, spurious, and chlaina, a cloak; in allusion to some of the species appearing to have an involucre. Sometimes written Notholana.

The very elegant plants arranged under this genus are of dwarf habit, and generally difficult to cultivate, owing to the woolly or scaly surface of the fronds, which retains moisture. When once they become wet the water does not readily pass off, and the fronds are in consequence often destroyed. It is therefore not advisable to sprinkle water on the fronds, but to keep them quite dry during winter. Fig. 5 represents a portion of the frond of Nothochlana trichomanoides.

1. N. TEnera, Gillies.-A very tender delicate evergreen stove Fern, from Chili. Fronds glabrous, bluish green, six to eight inehes high, somewhat laneeolate, bipinnate; pinnules on the lower pinnæ eordate-ovate, oblong-obtuse, superior ones beeoming sessile, terminal one lobed. Sori terminal, linear, continuous, eonfluent, forming a broad marginal band. Stipes shining, adherent to a short ereeping rhizome.

2. N. nivea, Desvaux (N. incana, Presl.; Pteris nivea, Poiret).-A very tender delicate beautiful evergreen stove species, native of Mexico, Peru, and Chili. Fronds from six to twelve inehes high, and covered beneath with white farinose powder, the upper surface bluish-green; somewhat laneeolate, with a broad base; bipinnate, with roundish ovate, obtuse, entire pinnules, which arc cordate at the base, tbe terminal one lobed. Sori terminal, linear, confluent, forming a broad marginal band. Fronds terminal, adherent to a short ereeping rhizome.

3. N. ARgenteA, J. H.-This, one of the handsomest of the genus, is an evergreen stove species, native of South America. Fronds triangularly ovate, about six inehes long, and covered throughout with white farinose powder; sub-tripinnate, with oblong obtuse crcnate pinnules, 
the lower ones distant. Stipes, rachis, and midrib of pinnæ shining black. Sori linear, terminal, consisting of a single row of sporc-cases, near the margin of each segment. Stipes scaly near the base. Fronds adherent to a somewhat creeping rhizome.

4. N. Trichomanomes, R. Brown (Pteris, Linncus).-A very handsome evergreen stovo Fern, from Jamaica. Fronds slender, pendulous, one foot long, linear, pinnate, covered especially beneath, with a white farinose powder, and brown stellate pubescence; pinnæ oblong, obtuse, bluntly lobed or crenate, cordate and auriculate at the base. Sori terminal, confluent, forming a linear continuous marginal band. Fronds terminal.

5. N. LAvis, Martens and Galeotti.-A beautiful evergreen warm greenhouse Fern, native of Mexico. Fronds linear-lanceolate, pinnate, a foot long, deep green on the upper surface, and densely covered beneath with imbricated fringed white scales, which ultimately becomc of a rich brown; upper surface scattered over with a stellate scaly pubescence; pinnæ stalked, cordato-oblong, round at the apex, inferior ones hastate, and sinuate, superior ones entire. Sori linear, continuous, sub-marginal, protruding through the scales, forming a broad black band. Fronds lateral or subterminal, adhercnt to a whitish, scaly, shortly-creeping rhizome. This plant has the venation and broad sori of a Platyloma, but is destitute of an indusium, the margin of the frond being quite flat.

6. N. Rufa, Presl (Chemanthes ferruginea, Willdenow).-A slender and rather straggling growing stove species, native of the West Indies and South America. Fronds narrow, linear, from twelve to eighteen inches long, woolly, pinnate; pinnæ ovate, oblong-obtuse, pinnatifid, with the stipes and rachis light brown. Sori terminal; marginal, forming a linear continuous row of little more than single spore-cases. Fronds adherent to a creeping rhizome.

7. N. Sinuata, Kaulfuss (Acrostichum, Swartz).-A very elegant evergreen stove Fern; native of Peru, Mexico, \&c. Fronds one to two feet long, reclining, linear, pinnate; pinnæ cordate-ovate, obtuse, pinnatifid, white on the under surface, and densely covered with imbricated fringed scales; upper surface bright green, scattered over with stellate pubescence. Stipes, rachis, and rhizome scaly. Sori terminal ; marginal, consisting of a few spore-cases, situated in the sinuses of the segments, protruding through the scales.

8. N. squamata, $J$. $H$.-A dwarf evergreen stove Fern; from Mexico and Peru. Fronds pinnate, about six inches long, rather ovate-lanceolate, scaly beneath, with oblong-obtuse, pinnatifid pinnæ, which are dark green above and whitish beneath. Sori terminal, continued round each segment of the pinnæ. This species is but little known in cultivation, although introduced about 1842.

9. N. lanuginosa, Desvaux (Acrostichum velueum, Aiton; N. vellea, Desvaux).-A very tender delicate evergreen greenhouse Fern; native of the South of Europe, Madeira, \&c. Fronds four to six inches high, very woolly and brownish on the under surface; linear-lanceolate, bipinnate, with roundish ovate pinnules, the terminal one lobed. Sori round, terminal, subsequently confluent. Rhizome short, somewhat creeping.

10. N. vestita, Desvaux (Cheilanthes, Swartz). [Plate I.]-A slender evergreen frame, or greenhouse species; native of various parts of North America. Fronds from five to ten inches long, densely covered with hairs; linear-lanccolate, bipinnate, with roundish ovate pinnæ, the pinnules pinnatifid; margin crenate. Sori round, terminal, marginal, subsequently confluent. Fronds adherent to a short creeping rhizome. This species is often sold for Woodsia ilvensis.

11. N. Distans, R. Brown.-A small evergreen grcenhouse Fern; from New Holland. Fronds six to ten inches long; linear-lanceolate, bipinnate, pinnules oblong obtuse, opposite, sessile and hairy. Sori terminal, marginal, confluent. Stipes, rachis, and midrib of pinna, covered with scales. Fronds adherent to a crecping rhizome.

12. N. Marante, R. Brown (Acrostichum, Linnaus; Ceternch, De Candolle).-A rather handsome evergreen Fern; found in the South of Europe and Madeira. Fronds from six to ten inches high, rather stiff, densely covered with scales on the under surface; ovate-lanceolate, bipinnate, with oblong obtuse pinnules, the lower one stalked, superior ones sessile, entire at the apcx. Sori terminal, and marginal. Fronds adherent to a thick, short, creeping rhizome.

13. N. tomentosa, Desvaux (Chemantues, Linh).-A woolly evergreen stove species; from Mexico. Fronds very handsome, about a foot long, tripinnate, with oblong-linear pinnules, and very small segments, which are roundish ovate distant and concave, the terminal one larger. Sori consisting of a few spore-cases on cach segment. Rhizome short, creeping.

14. N. Ecrloniana, Kunze.-This evergrcen Fern, the most beautiful species of the scaly section, is a native of the Cape of Good Hope, and is best cultivated in a warm greenhouse. Fronds nearly a foot long, covered on all parts with narrow white scales which give them a woolly appearance; they are rather ovate, tripinnate, with oblong-obtuse pinnules, and small roundish ovate segments, crenate and concave, the margin revolute; lower ones distant, superior ones sessile. Sori terminal, consisting of a single row of spore-cases on each scgment, partly concealed by the revolute margin. Rhizome creeping.

\section{GYMNOGRAMMA, Desvaux.}

Sori linear, simple, or often forked, oblique, at length confluent; spore-cases medial, superficial, oceupying nearly the whole length of the venules, and sometimes echinate. I eins forked, or pinnate ; 
venules simple. Fronds varying from a few inches to three or four feet long; simple pinnate bipinnate or decompound; smooth hairy or covered beneatle with a rich.coloured farinose* powder.Name derived from gymnos, naked, and gramme, a line; in allusion to the linear sori being destitute of a cover.

In the Gardeners' Magazine of Botany we have adopted the genus Leptogramma, distinguishing it from Gymnogramma by the simple venules and simple sori, which characterized the original; but several additional species have now been introduced to cultivation, which while they agree in having

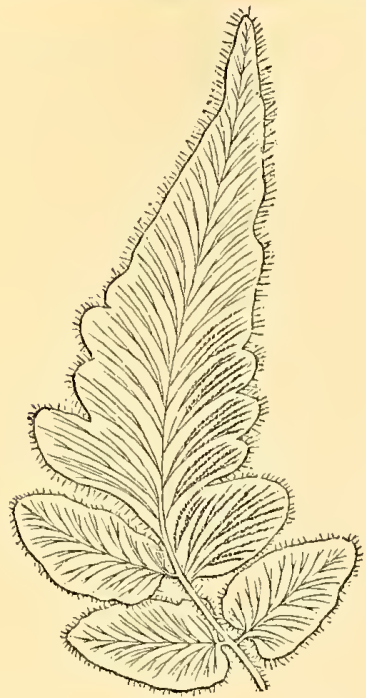

Fig. 6. simple sori with the characters assigned to Leptogramma, yet do not accord in the venation. Hence it becomes necessary to cancel Leptogramma as a genus; but it may be usefully retained as a scctional group, to include those species which are distinguished from true Gymnogramma by oblong-linear simple sori.

Fig. 6 represents a pinna of Gymnogramma tomentosa (med. size).

$$
\text { Q Grimooramma vera.-Sori linear, forked. }
$$

1. G rufa, Desvanx (Hemionitis, Swartz; Neurogramma, Link). 一 An ornamental evergreen stove specics; native of tropical America. Fronds from one to two feet long, hairy, linear, pinnate with oblong, obtuse pinnæ, stalked, and cordate at the base. Stipes and rachis reddish brown; terminal, adherent to a fasciculate erect rhizomc. Sori linear medial, forked, oblique, subsequently confluent, produced on evcry pinnæ throughout the frond.

2. G. tomentosa, Desvaux (Hemionitis, Raddi; Neurogramma, Link ; Ceterach lobatum, Presb). - A tender delicate and beautiful stove Fern; native of Brazil and the West Indies. Fronds somewhat lanceolate, bipinnate, hairy, and membranous, from one to two fect long, with oblong-obtuse pinnules, the lower oncs cordate at the base, terminal one lobed, acuminate. Sori lincar, medial, forked, obliquc. Stipes and rachis black, terminal, adherent to a fasciculate crect rhizome.

3. G. JAvanica, Blume.-A very handsome evergreen stove Fern; from Java. Fronds glabrous, pinnate, two to three feet high, bright green; pinnæ petiolate oblong-lanceolate, six to ten inches long, acuminate, or subcaudate at the apex, and cuneate at the base. This species is rare in English gardens, thongh it has been in cultivation on the Continent for scveral years.

4. G. trifoliats, Desvaux (Acrostichum, Linnans).-A rather erect growing evergreen stove Fern; from the West Indies. Fronds oblong-lanceolate, broadest at the base, bipinnate, one to one-and-a-half foot long, light grcen; pinnæ petiolate, trifoliate, with linear-lanceolate segments, slightly crenate at the margin, and covered bencath with a yellowish farinose powder. Stipes scaly at the basc, terminal, adherent to a fasciculate erect rhizomc. This species, which is scarce in cultivation, has often been brought to the country, but is difficult to establish ; it has recently been introduced to the Royal Botanic Garden, Kew.

5. G. Calomelanos, Kaulfuss (Acrostichum, Limmaus; Ceropteris, Link).-An ornamental evergreen stove Fern; from Jamaica. Fronds from two to three feet long, ovate-lanceolate, bi-subtri-pinnate, the upper side dull green, and covered bencath with a white farinose powder; pinnules lanceolate-acuminate, with elongated acuminate lobed segments. Sori forked, medial, oblique, confluent, and nearly covering each segnient. Stipcs, rachis, and midrib of pinnæ black; terminal, adherent to a fasciculate crect rhizome. This plant frequently goes under the name of $G$. pervivina, in gardens.

6. G. Tartarea, Desvaux (Acrostichum, Swartz; Ceropteris, Link; G. Dealbata, Link),一An ornamental evergreen stove species; from the warm parts of America. Fronds two to three feet long, ovate-lanceolate, bi-subtri-pinnate; the upper surface dull grcen, and covered beneath with a white farinose powder ; pinnules lanccolate-acuminate, with roundish ovatc or oblong segments, which are distant, the lower one lobed. Sori linear, medial, forked, oblique, becoming confluent. Stipes, rachis, and midrib of pinnæ black; terminal, adherent to a fasciculate erect rhizomie.

7. G. ochracea, Presl?-An evergreen stove Fern; from Peru. Fronds from one to one-and-a-half foot long, ovate-lanceolate, pale yellow beneath, the upper surface bright green; bipinnate, with lanccolate-acuminate pinnæ, and narrow oblong-linear dentate pinnules. Sori mcdial, somewhat scattcred on the veins. This, which has the most compact frond of the yellow farinose species, is in cultivation under the namc of G. Massoni.

- The farinose powder, which is found on the fronds of many species of Gymnogramma and other genera of Felns, is not always of the same colour throughout the frond. We have reeeived from Mr. W. H. Baxter, of the Botanie Garden, Oxford, a frond of Gymnogrammatartarea, whieh has both the white powder proper to the species, and the bright yellow proper to $G$. chrysophylla, on distinct portions of the same frond. 
8. G. Chrysophylla, Kaulfuss (CERopteris, $\operatorname{Lin} k$ ).-One of the most beautiful of exotic Ferns in eultivation. It is an evergreen stove species; from the West Indies and South America. Fronds from one to two feet long, eovered beneath with a farinose powder of the richest golden yellow, the upper surface yellowish green; bipinnate having lanceolate acuminate pinnæ, and roundish ovate or oblong pinnules, slightly dentate, distant, pinnatifid, with medial sori scattered on the veins; terminal, adherent to a fasciculate erect rbizome. Tbis Fern, like most others, varies in cultivation according to tbe treatment it receives; if subjected to a low temperature, and a rather dry atmospbere, the fronds do not exceed ten inches high, are nearly triangular and of the most intense golden yellow; but if in a temperature of $85-90^{\circ}$ Fahrenheit, with proportionate moisture, it then becomes more compound, two feet high or more, the segments of the pinnules more serrated, and of an exceedingly brigbt yellow.

9. G. Martensii, Bory (G. MertensiI, of gardens).-An elegant evergreen stove Fern; from South America. Fronds delicate, very fragile, one and a-half foot long, covered beneath with a rich yellow farinose powder, tbe upper surface yellowish green; ovate-lanccolate, bipinnate with lanceolate pinnæ, and roundish or elongated pinnatifid pinnules, with dentate segments. Sori medial, eonfluent, covering nearly every segment of the frond. Rhizome tufted.

10. G. surrnurea, Desvaux.--A very elegant dwarf evergreen species; from Jamaica. Fronds fronl six to ten inches long, fragile, and very delicate, the under surface covered witb a farinose powder of a bright sulphur yellow, upper surface pale green; bipinnate with lanceolatc-acuminate pinnæ, and oblong-obtuse pinnatifid pinnules, cuneate at the base, tbe margins dentate. Sori linear, forked, oblique, confluent, nearly covering each segment of the pinnules. Fronds terminal, adherent to a fasciculate erect rhizome.

11. G. cherophylua, Desvaux (Anogramma, Link).-A tender delicate fragile annual stove Fern; native of the West Indies and various places in South America. Fronds decompound, triangular, bright green, from six inches to a foot higb, with roundish ovate pinnatifid pinnules, deeply dentate, and cuneate at the base. 'The fertile fronds are erect, and the pinnules very much contracted.

12. G. Leptophrma, Desvaux (Anogramia, Link; Gramiris, Swartz; Polypodium, Linnous).-An extremely delicate annual stove species; from the South of Europe, Madeira, \&c. This little Fern attains the height of but a few inches. Its fronds are smooth, somewhat deltoid, bipinnate, with rouudish cuneate, two or three lobed pinnules, and each lobe bluntly dentate. Sori forked, confluent. Fertile fronds not eontracted, and nearly all are fertile.

13. G. Graclle, T. $\boldsymbol{M}$.-A delicate fragile stove Fern; supposed to be a native of South America. Fronds about a foot higb, pale grcen, sparingly covered beneath with white farinose powder ; ovate-triangular, acuminate, bipinnate; pinnules inciso-pinnatifid, decurrent at the base, the scgments cuneate-bifid or emarginate, the divisions entire and retuse. Stipes long, and as well as the rachis and costa purplish. Rhizome short cæspitose. Our specimens are imperfect, but they appear distinct. It was introduced to the nursery of Messrs. Henderson of St. Jobn's Wood last year, and was obtained from Mr. Linden. It seems closely allied to $G$. conspersa, Kunze, from Natal.

$$
\text { z Leptograma.-Sori simple, linear-oblong. }
$$

14. G. villosa, Link (Leptograma, J. Smith).-A beautiful evergrcen stove Fern; from Brazil. Fronds hairy, somewbat lanceolate, bipinnatifid, about two feet long, reclining, with linearlanceolate acuminate pinnæ, and rather ovate, bluntly acuminate segments. Sori oblong, submedial, oblique. Fronds lateral or terminal, adberent to a cospitose creeping rhizome. Fig. 7 represents the upper part of a pinna of $G$. villosa, of medium size.

15. G. Gracile, Heward (Leptograma, J. Smith).-A ratber erect growing evergreen stove Fern; from Jamaica. Fronds lanccolate-elongate, pinnate, one and a-half to two feet long, pale green, pubescent throughout; pinnæ sessile, oblong-acuminate; middle ones four to five inches long, gradually decreasing to the base, where tbey are only a quarter of an inch long; all deeply pinnatifid, with oblong-linear repand segments, round at the apex, and crenate at the margin. Stipes about an inch long, with a few scales at the base. Fronds nearly all fertile throughout; terminal, adherent to an erect rhizome. This species was introduced to English collections in 1851.

16. G. ToTTA, Sehleehtendal (G. Loveir, Hooler et Greville).-An ornamental evergreen warm greenhouse Fern; a native of Madeira and tbe Cape of Good Hope. Fronds very hairy, lanceolate, pinnate, one to one-and-a-half foot long, palish green; pinnæ sessile, oblong, obtuse at the apex, pinnatifid, upper ones adnate-decurrent, with blunt lobes. Veins forked or pinnate, the inferior pair of renules occasionally anastomosing. Stipes scaly; terminal, adherent to a decumbent, scaly creeping rhizome.

17. G. Repens, $M$. and $H$.-An ornamental deciduous stove Fern; a native of the East Indies. Fronds slender, broadly lanceolate, one to two feet long; light green, pinnate ; pinnæ remote, oblong-acuminate, four to five inches long, rather membranous, the inferior pair or more petiolate, the superior adnate, pinnatifid, with oblong rather obtuse segments, crenate or bluntly lobed and hairy on the margin; the pair next the racbis much larger than the others, and deeply pinnatifid with round lobes. Rachis and stipes terete, with a few scales at the base; lateral, adberent to a creeping rhizome, about the size of a goose quill. Tbis Fern has been in cultivation for ten or twelve years.

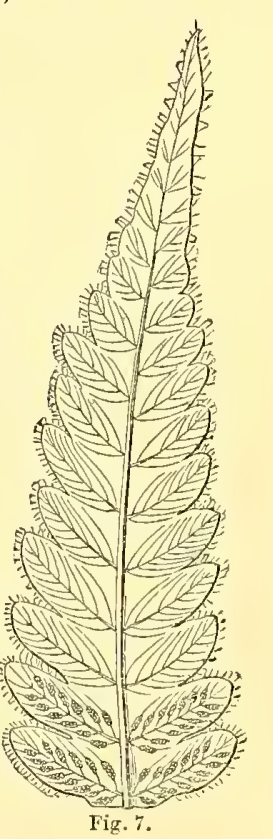

Fig. 7 . 
SEct. Symplophlebies, J. Smith (from symploke, connection, and phleps, a vein).-Veins anastomosing, so as to form a network.

VII. MENISCIUM, Schreber.

Sori lincar, medial, somewhat transverse, arcuate or crescent-shaped, continued across the junction of two anastomosing venules, and subsequently bccoming confluent. Veins pinnate, curved, somewhat parallel; venules arcuate, or angularly anastomosing, producing from their junction an excurrent veinlet, free, or uniting with the anastomosing venules above, dividing the surface of the frond throughout into numerous rectilinear parallelograms. Fronds from one to five feet long, smooth or hairy, simple pinnate or ternate; pinnæe entire, crenulate, or serrulate--Name derived from meniskos, a crescent; the fructification forming short curved lines.

The venation in some of the species of this genus is not distinguishable from that of some Nephrodiums. The only technical character by which Meniscium can be distinguished is the arched or arcuate sori, by which, however, it is readily known. Fig. 8 represents a portion of the base of a pinna of Meniseium palustre (nat. size).

1. M. stmplex, Hooker.-A dwarf evergreen stove Fern, from China. Fronds simple, pubescent, somewhat elliptical or oblong-acuminate, dentato-serrate, from six to twelve inches long, dull green, cordate at the base, and sub-hastate; lateral, adherent to a slender scaly creeping rhizome. Sori medial. This species is of recent importation, having been introduced to Kew from Hong Kong in the latter part of 1850 .

2. M. palustre, Raddi (M. Dentatum, Presl-fide Kunze).-A tall robust evergreen stove spccies, from South Amcrica. Fronds glabrous, rather erect, somewhat ovate-lanceolate, pinnate, from three to five feet long; pinnæ entire, lanceolate, acuminate, coriaceous, from six to ten inches long, lively green, slightly undulated, and roundish or cuneate at the base; the lower pairs of pinnæ often proliferous at their base. Stipes dark-coloured near the base; lateral, adherent to a thick creeping rhizome. Sori medial, subsequently confluent.

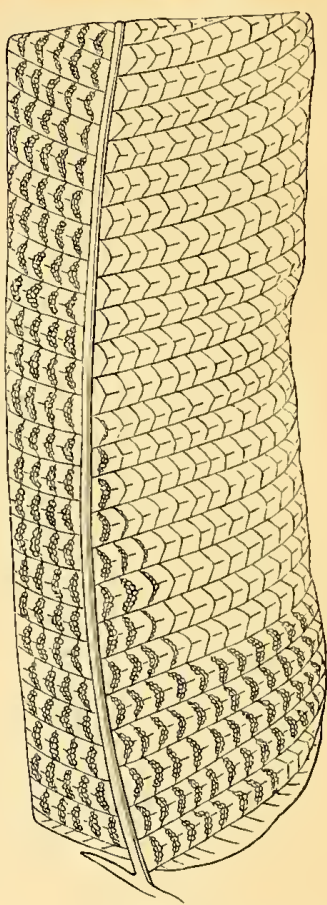

Fig. 8.

3. M. Reticulatum, Swartz (Polypodium, Linnaus).-A tall robust evergreen stove Fern, native of the Wcst Indies. Fronds four to six feet high, lanceolate, pinnate; pinnæ lanceolate, acuminate, six or seven inches long, membranous, obliquely cuneate at the upper base, rounded below, repand, serrate; viviparous in the axils. We have not seen fertile fronds of the cultivated plant, which, however, we refer with littlc hesitation to the species of Swartz above quoted.

\section{GONIOPTERIS, Presl.}

Sori round, medial, or costal. Spore-cases sometimes echinate. Veins pinnate; venules angularly anastomosing, producing from their junction an excurrent free or anastomosing sterile veinlet. Fronds from one to two feet high, pinnate; pinne entire, serrate, crenate, or pinnatifid; when dceply pinnatifid, the inferior pair of venules only anastomose, the superior ones being all free.-Name derived from gonia, an angle, and pteris, a fern; in allusion to the angular anastomosing of the venules.

The species of Goniopteris are easily cultivated, and have usually a neat appearance, being of nearly uniform size. The primary character of the genus lies in the round and naked sori, which are moreover medial, costal, sub-marginal, or basal; the venation affords no trustworthy distinguishing character, for the veins are arranged exactly as in some species of Meniscium and of Nephrodium. Fig. 9 represents a pinna of Goniopteris crenata (med. size).

1. G. reftans, Presl (Polypodium, Swartz; P. radicans, Lamarck).-A prostrate-growing, evcrgreen hothouse Fern, from Jamaica. Fronds lax, slender, elongate, pubescent, pinnate, a foot or more long, light green, and rooting at the apex; pinnæ petiolulate, inferior oncs oblong-ovate, cordate at the base, and round at the apex; superior oncs auriculate, and semiorbicular, truncate at the base, crenate at the margin. Fronds terminal, adherent to a somewhat tufted rhizome. Sori uniserial. Introduced to Kew in 1852.

2. G. GRAcilis, $M$. and $H$.-An interesting evergreen stove Fern, from Jamaica. Fronds slender, narrow, lanceolate, pinnatc, minutely pubescent, one to one and a half foot long, deep green, and proliferous near the apex; lower pinnæ small, distant, petiolulate, cordate-oblong, obtusc at the apex, pinnatifid, with round lobes; 
middle ones sessile, falcate, adnatc, oblong-hastate ; upper ones small, semi-orbicular, distinct or confluent at the base, entire on the margin. Sori uniserial or biscrial, with a tuft of forked or stcllate hairs in cach sorus. Fronds terminal, adhercnt to a rather ercet-growing rhizome. The plant is covered throughout, especially beneath, with small forked or stellate pubescence. The sterile fronds have a great similarity to $G$. asplenioides. It was introduced to Kew in 1852 .

3. G. Aspleniones, Presl (Polypodium, Swartz; P. compositum, Link). [Piate II.]-An ornamental, evergreen stove Fern, from Jamaica. Fronds lanceolate, pinnate, rugose, pubescent, about one foot long, dullish green, with oblong obtuse pinnatifid pinnæ, somcwhat cordate at the base; terminal, adherent to a short creeping rhizome. Sori medial, or subterminal, subsequently confluent.

4. G. Fraxinifolia, Presl (Polypodium, Jacquin; P. Proliferum, Kaulfuss; P. Freyreissin, Sprengel).-An elegant evergreen stove species, from Brazil. Fronds lanceolate, pinnate, two feet long, with entire lanceolateacuminate smooth shining pinnæ, which are dark grcen, truncate, or occasionally auriculate at the upper base, and proliferous throughout. Sori medial, triserial, and subsequently confluent. Fronds terminal, adherent to an erect fasciculate rhizome.

5. G. chenata, Presl (Polypodium, Swartz).-A very handsome evergrcen stove Fern, native of the West Indies. Fronds ovate-lanceolate, one and a half to two fect long, pinnate, with entire oblong ovate-acuminate membranous crenate pubescent pinnæ, pale green, roundish or obliquely truncate at the base, with very short petioles. Sori medial, in four to eight series. Rachis and stipes green; lateral, adherent to a short creeping rhizome.

6. G. Affinis, $M$. and $H$.-An ornamental cvergreen stove Fern, from Jamaica. Fronds somewhat lanceolate, pinnatc, one to two feet long, palish green; pinnæ glabrous, lanceolate, four to seven inches long, and about one inch wide, lower ones petiolulate, upper sessile, pinnatifid, obtusely lobed, acute at the apex, unequal or slightly cordate at the base. Stipes with a few scales at the base; terminal, adherent to a decumbent somewhat creeping rhizome.

7. G. megalodes, Presl (Polypodium, Schkuhr). - An ornamental evergreen stove Fern, from the West Indies. Fronds oblong-acuminate, broad at the base, pinnate, pubescent, pale green, from two to thrce feet long, with linear-lanceolate, acuminate, pinnatifid, rather membranous pinnæ. Sori medial. Stipes and rachis green; lateral, adherent to a short crceping rhizome.

8. G. Fonsteni, $\boldsymbol{M}$. and $H$.-A rather rugose-looking evergreen warm greenhouse Fern, from New Zealand. Fronds lanceolate, pinnate, one to two fcet long, dull green; pinnæ sessile, lanceolate, cordate at the base, lower ones short, pinnatifid, with roundish obtuse segments, ciliated and crenulate at the margin. Rachis and stipes tetragonal, with a few scales at the base. Sori medial, or produced near the junction of the venules

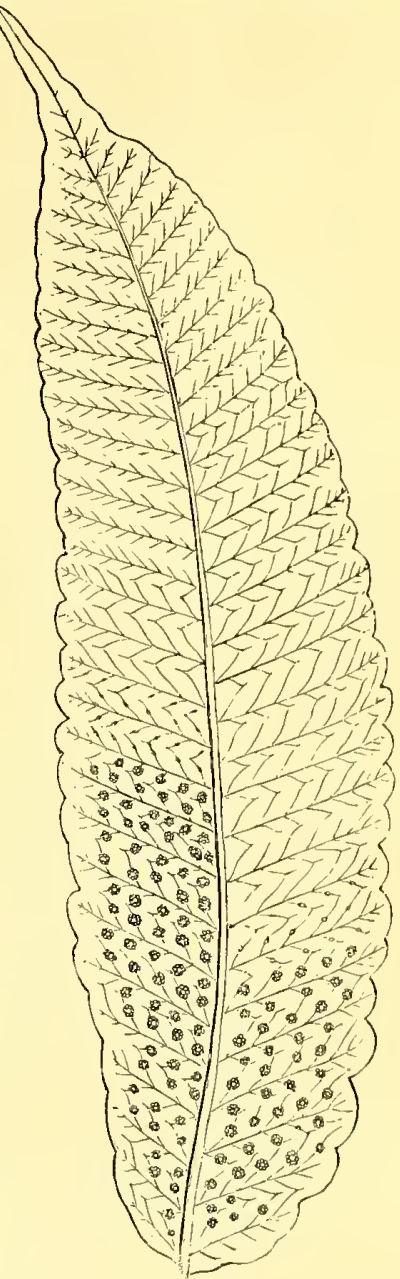

Fig. 9. and confluent. Fronds terminal, adherent to a rather crect-growing rhizomc. This plant, which is scarce in cultivation, although grown in Britain nearly thirty years ago, has recently been re-introduced to Kew. It is doubtless the Polypodium pennigerum of Forster; but as that specific name is preoccupied in this genus, owing to a confusion which has arisen between the present and following species, and a supposed "Aspidium" which rescmbles them, it seems to us better to cancel the name pennigerum, and distinguish Forster's plant by a new name.

9. G. Tetragona, Presl (Polypodium, Swartz; P. Smithinam, Heward).-An ornamental evergrcen stove Fern, from the West Indies. Fronds somewhat lanceolate, pinnate, minutely pubescent, from one to two feet high ; pinnæ sessile, lanceolate-acuminate, bright green; lower ones petiolulate, standing forward and tapering to the base, upper ones truncate or slightly cordate at the base, pinnatifid, with repand or slightly falcate, acute (in the fertile often rounded or obtuse) scgments. Fertile fronds erect, usually more or less contracted; pinnæo indistinctly articulated with the rachis, which is flattened above, and of a pale green. Sterile fronds shorter than the fertile, and more dilated. Sori medial, uniserial, the lower ones subsequently confiuent. Fronds terminal, adherent to a short creeping rhizome.

10. G. Prolifera, Presl (Meniscium, Swartz).-A straggling-growing evergreen stove Fern, from the East Indies. Fronds pale green, slender, usually linear-lanceolate pinnate, two to three feet long, with ollongacuminate, membranous, pubescent pinnæ, slightly cordate at the base, and crenato-dentate at the margin. "Ihis Fern grows freely, and is very proliferous, but without fructification, sometimes growing to a great length, but very narrow. Fronds lateral, adherent to a creeping rhizome. 


\section{GONIOPHLEBIUM, Presl.}

Sori round, terminal, naked or squamiferous, arranged in one or more transverse parallel rows. Veins forked or pinnate; lower exterior venule free and fertile, the others angularly anastomosing, producing from their junction an excurrent, free, and generally fertile veinlet. Fronds from a few inches to five or six feet long, smootlı hairy or scaly, simple pinnatifid or pinnate, the pinnæ entire, articulate, serrulate or undulate.-Name derived from gonia, an angle, and phleps, a vein; in allusion to the angles formed by the anastomosing of the venules.

This is an exceedingly variable genus, with regard to the size of the plants and circumscription of their fronds. The dwarf kinds have the fertile fronds eontracted, while the larger speeies have their fronds all of one form; but they agree in having a sealy, creeping rhizome. The species are commonly found adhering to the trunks of trees in tropical forests; several of them are amongst the most elegant of the Ferns in eultivation. The eharacters by which they are determined from all congeners, are: the round terminal sori, the angular anastomosing of the venules, and the presence of an excurrent generally soriferous veinlet in the costal areole. Fig. 10 shows a pinna of Goniophlebium meniscifolium (full size).

3 LOPHOLEPrs, $J$. Smith. -Sori furnished with a dense tuft of elongate scales.

1. G. PILosellordes, $J$. Smith (Polypodiux, Linnous).-A dwarf, evergreen stove species, from the West Indies. Fronds of two kinds: sterile-simple, hairy, light green, ovate or oblong, decurrent at the base, from one to two inches high : fertile-simple, hairy, linear-oblong, decurrent at the base, from two to three inches long; both are articulated on a very slender, crceping rhizome. Sori scated in a tuft of narrow scalcs, uniserial.

z LEPICYSTIS, $J$. Smith.-Sori protruding through the densely-scaly under surface of frond.

2. G. Lepidopteris, $M$. and $H$. (Polypodium, $K u n z e ; G$. sepultum, $J$. Smith; P. sepultur, Kaulfuss; P. nufulum, Presl; P. Hirsutissimum, Raddi; Acrostichum Lepidopteris, Langsdonf and Fischer; Marginaria rufula, Presl).-An elegant, evergreen stove species, from South Ameriea. Fronds truly lanceolate, pinnate, from six inches to a foot long, dcnsely covered throughout with narrow, fimbriated scalcs, whieh give them a pale tawny colour; pinnæ close, sessile, oblong-lincar, rather obtuse. Sori uniserial on the upper half of the frond, protruding through the scales. Veins internal, indistinctly secn when dry. Fronds articulated on a whitish erecping rhizome, whieh is densely clothed with brown chaffy seales.

3. G. albicans, $M$. and $I I$.-A very scaly evergreen stove Fern, from Mexico. Frond somewhat lanceolate, broad at the base, pinnate, one to two feet long, dark green above and densely covered throughout, especially beneath, with elongated pcltate-stcllate seales, whieh produce a whitish appcaranee; pinnæe adnate lincar-lanccolate, one to three inches long, approximate, aurieled on the upper base, inferior pair or more sub-petiolate, rather obtuse at the apex, entire at the margin. Sori uniserial, protruding through the scales on the upper half of the fronds. Fronds lateral, articulated with a creeping rhizome, which is about the size of a goose-quill, densely elothed with small appressed seales. This Fern is in cultivation under the name of $G$. sepultum; but it is very distinct from that species-the fronds being mueh larger, of a different outline, and the rhizome clothed with a very different kind of seale. It has been in eultivation about ten years, and was originally introduced among somc orchids.

3 Sciellolepis, J. Smith.-Sori sunk in a carity, forming a protuberance on the upper surface of the frond.

4. G. ARgutum, J. Smith (Polypodrum, Wallich).-A beautiful evergreen stove Fern, from Nepal. Fronds glabrous, slender, from two to threc fect long,

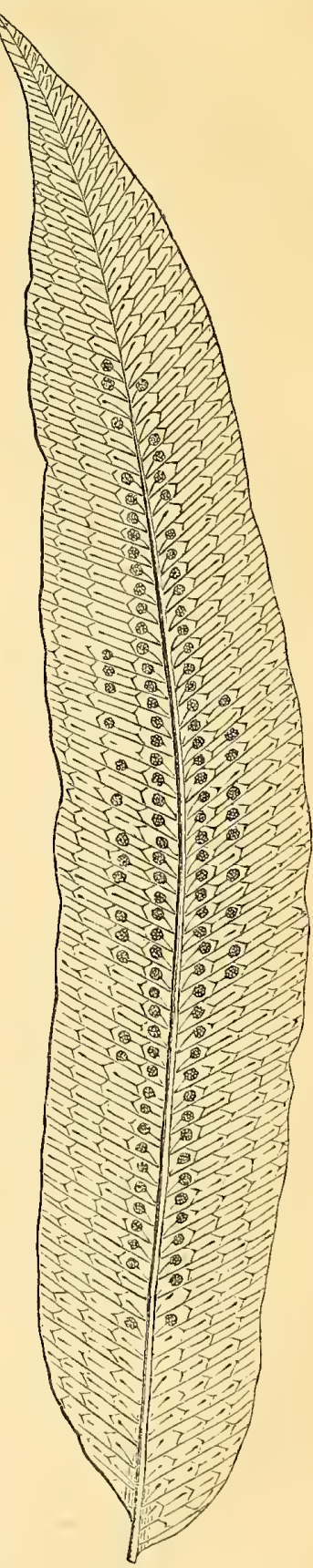

Fig. 10. the rachis and stipcs pale brown, shining, and articulated on a scaly, creeping rhizome. Fronds pinnate, 
lanccolate, with lanceolate-acuminate, rather membranous, bright green pinnæ, which are articulated with the rachis, serrated, and decurrent at the base. Sori large, uniserial, yellowish brown, each furnisked with numerous laciniated scales, which are soon obliterated by the spore-cases; they are immersed, forming clevated protuberances on the upper surface of the frond.

5. G. verrucosum, J. Smith.-An ornamental evergreen stove species, from the Philippine Islands and Singapore. Fronds slender, slightly pubescent, four to five feet long, pendulous, lanceolate-acuminate, with oblong-acuminate, undulated, bright green pinnæ, which are slightly scrrated, round at the base, and articulated with the rachis. Sori uniserial, immersed, forming elevated protuberances on the upper surface of the frond. Rachis and stipes scaly, and articulated with a creeping rhizome.

6. G. subauriculatum, Presl (Polypoduun, Blume; G. Retnivardtii, De Triese; P. Reinwardtii, Kumze). $-\Lambda$ very elegant evergreen stove species, from Java and Luzon. Fronds slender, lanceolate, piunate, from four to six feet long, with long, narrow, lanceolate-acuminate, membranous bright green pinnx, which are serrate, subauriculate at the base, and articulated with the rachis. Sori uniserial, yellowish brown, each furnished with numerous laciniated scales, which are soon lost by the swelling of the spore-cases; they are immersed, forming elevated protuberances on the upper surface. Rachis and stipes brown, pubescent, articulated with a scaly creeping rhizome. This species is one of the most beautiful of the Polypodiec, and the most ornamental of all herbaceous species yet in cultivation; the fronds being long, very slender and pendulous, measuring sometimes eight feet long, and having fifty-eight pairs of pinnæ, with a stipcs not more than eight inches long.

GONIOPHLEBIA VERA, $J$. Smith.

7. G. vaccinifolium, J. Smith (Polypodium, Langsdorf and Fischer; Craspedaria, Linh).-A dwarf, creeping, evergreen, stove species, from the West Indies and South America. Fronds of two kinds: sterile-simple glabrous, sub-rotund or oblong, decurrent at the base, dark green, about half an inch high : fertile-linear, simple glabrous, two inches long, decurrent at the base. Both kinds are lateral, articulated on a thick, brown, scaly creeping rhizome. Sori terminal, uniserial.

8. G. Catharinke, J. Smith (Polypodium, Langsdorf and Fischer; P. Glaucum, Raddi).-A handsome, stiff-growing, stove Fern, from Brazil. Fronds one foot to a foot and a-half high, somewhat lanceolate, broad at the base, with an elongated bluntish point, dark green, paler beneath, quite smooth; subpinnate below, deeply pinnatifid above; pinnæ approximate, elongate-oblong, undulated, entire, narrowed near the base, and very blunt at the apex, the lowest shorter, standing forward, and decurrent at the base. Sori uniserial near the costa, extending from the base to the apex of the frond, and from the base nearly to the apex of the segments. Stipes smooth, a little margined upwards. Fronds articulated with a thick, green, creeping, caspitose rhizome, which is covered with imbricating, ovate-acuminate peltate, dark-coloured scales. New-hay-scented when dry. We are indebted to Mr. Henderson, of Wentworth, for this species, which is undoubtedly the Polypodium glaucum of Raddi, and distinct from $G$. Catharine, of gardens.

9. G. Latipes, J. Smith (Polypodium, Langsdorf and Fischer; G. CAtharinde, of gardens).-An evergreen ornamental stove Fern, from Brazil. Fronds glabrous, oblong-elongate or broadly-lanceolate, deeply-pinnatifid or sub-pinnate, broad at the base, from one to two feet long, dull green; segments lanceolate, three to six inches long, acutish or obtuse at the apex; lower ones undulated, standing forward, sub-deflexed, and crenulate on the margin. Sori uniserial. Fronds lateral, articulated on a creeping rhizome, which is densely covered with imbricate, peltate, acuminate, brown scales.

10. G. Loriceum, $M$. and H. (Polypodium, Linnares; P. Ramosum, Loddiges: G. Latipes, of gardens).Fronds glabrous, lanceolate, deeply pinnatifid or subpinuate, slender, and somewhat pendulous, from one to two feet long, dull green, segments linear-oblong, rather membranous, acute or acuminate at the apex, undulated, slightly falcate, and crenulate at the margin. Sori small, uniserial or biserial. Fronds lateral, articulated on a green creeping rhizome as large as a swan's quill, which is covered with peltate, fimbriate scales.

11. G. harpeödes, J. Smith (Polypodium, Linh).-A tall-growing evergrcen stove species, from Brazil. Fronds glabrous, broadly-lanceolate, three to four feet long, dull green, erect, the stipes nearly half the length of the fronds; they are articulated on a short, thick, scaly, creeping rhizome. Frond deeply pinnatifid or subpinnate, with lanceolate-acuminate, nearly cntire, scimetar-shaped pinnæ, the lower ones standing forward. Sori läge, yellowish brown, uniserial.

12. G. vacillans, $M$. and $H$. (Polypodium vacillans, Link; P. Repandulum, Traulfuss).--An evergreen stove Fern, from Brazil. Fronds glabrous, triangularly.elongate, subpinnate, one and a half to two feet long, darkish green; segments linear-lanceolate, adnate, repand, dilated on both sides at the base, obtuse at the apex, entire at the margin. Sori uniserial. Fronds lateral, articulated on a creeping rhizome. This Fern is in the collection of G. Norman, Esq., of Hull.

13. G. scbpetiolatum, $M$. and $H$. (Polypodidi, $H o o k e r$ ).-A large evergreen greenhouse Fern, from Mexico and Guatemala. Fronds pubescent, lanceolate, two to three feet long, pinnate; pinnæ without a footstalk, four to six inches long, linear, attenuated at the apex, and irregularly crenato-serrate. Sori uniserial; nearly all the fronds soriferous throughout. Fronds lateral, articulated on a scaly creeping rhizome. Specimens of this Fern, recently communicated from Wentworth, prove it to be, when fully developed, a species of Goniophlebium; though when in a less vigorous condition the veins are free. 
14. G. Dissimle, $J$. Smith (Polypodium, Linnaus).-A handsome evergreen stove Fern, from the West Indies. Fronds slender, pendulous, two to three feet long, pubescent, pale green, lanceolate, pinnate, the pinnm distant, sessile, sub-falcate, lanceolate-acuminate, membranous, undulated, and somewhat deflexed, the lower ones standing forward. Sori biserial. Fronds articulated on a scaly, creeping rhizome.

15. G. albo-Punctatum, J. Smith (Poly Podium, Raddi).-A very ornamental evergreen stove species, from Brazil. Fronds broadly lanceolate, pubescent, pale green, from two to three feet long, the upper surface scattered over with small white scales; they are lateral, articulated on a short, scaly, creeping rhizome. Fronds pinnate, with lanceolate-acuminate, ncarly entire, membranous, undulated pinnæ, having the inferior base truncate, and the superior adnate; the upper ones are sessile. Sori uniserial.

16. G. Meniscifolium, J. Smith (Poly Podium, Langsdorf and Fischer; P. Longlfolium, Presl; P. PresliaNum, Sprengel-fide Kunze).-A tall, glabrous, evergreen, stove species, from Brazil. Fronds lanceolate, three to four feet long, pinnate, with lanceolate-acuminate, undulated, shining, bright green pinnæ, from six to eight inches long, having their inferior base roundish, and the upper one adnate. Sori large, yellowish brown, generally biserial. Stipes and rachis green, lateral, articulated on a thick, scaly, creeping rhizome.

17. G. Distans, $M$. and $H$. (Polypodium, Raddi; Marginaria distans, Presl; G. Deflexum, of gardens).An ornamental, evergreen, stove Fern, from Brazil. Fronds glabrous, two feet long, pinnate, with lanceolateacuminate, coriaceous, undulated, deflexed pinnæ, of a dull green, roundish at the base, and articulated with the rachis; the lower pinnæ are sometimes divided. Sori triserial. Stipes and rachis blackish green, lateral, articulated on a moderately thick, scaly, creeping rhizome.

\section{CYRTOPHLEBIUM, $R$. Brown.}

Sori round, naked, lateral or tcrminal, arranged in two rows between and parallel with the primary veins, or irregular. Veins pinnate or forked; lower exterior venule free and fertilc, the others arcuately or angularly anastomosing, producing from their exterior side two or more excurrent, free, fertile veinlets, which are sometimes very short, often uniting with the next superior venules, forming two rows of areoles between each two primary veins. Fronds simple or pinnate, from one to three feet long, glabrous, coriaceous or somewhat mcmbranous. Rhizome creeping.-Name derived from kyrtos, curved, and phleps, a vein; alluding to the convex or curved form of the venules.

There are various technical characters by which to distinguish this genus from the prceeding ones, some of them of minor importance, and perplexing unless to a practised eyc; the most essential, however, and those by means of which it is easily recognised, are the arcuate venules, combiried with two series of sori, between each two of the primary vcins. Fig. 11 represents the upper portion of a frond of Cyrtophlebium repens (nat. size).

1. C. angustifolium, J. Smith (Polypoduum, Swartz; P. Dimorphum, Link; Marginaria dimorpha, Link; M. angustifolia, Presl). - A slender evergreen stove Fern, native of the West Indies and South America. Fronds glabrous, simple, linear, attenuate, very narrow, reclining, with a somewhat revolute margin, coriaceous, from a foot to a foot and a-half long, dull green, decurrent at the base; lateral, articulated on a short, creeping, scaly rhizome. Sori medial; veins immersed. There are two forms of this plant.

2. C. repens, J. Smith (Polypodium, Swartz; Campyloneurum, Presl). -A creeping evergreen stove species, from the West Indies. Fronds simple, reclining, lanceolate-acuminate, from one to one and a-half foot long, glabrous, undulated, rather membranous, deep green, decurrent at the base. The upper surface of the fronds is scattered over with white scales, attached opposite the apex of each veinlet. Sori round, terminal. Fronds lateral, articulated on a scaly, slender, creeping rhizome.

3. C. Nitidum, J. Smith (Polypodium, Kaulfuss; Campyloneurum, Presl). -A rigid and rather erect-growing stove Fern, native of the West Irdies. Fronds glabrous, from onc to two fect long, coriaceous, undulated, dcep green and shining, lanccolate- 
acuminate, decurrent at the basc ; lateral, articulated on a short, scaly, crecping rhizome. Sori medial or termi. nal; veins indistinet.

4. C. Pryllitidis, J. Smith (Polxpodium, Limneus; Campyloneunum, Presl). -A rigid and rather ereetgrowing stove Fern, from the West Indies. Fronds simple, glabrous, from one to two and a-half feet long, rather narrow, slightly undulated, pale green, lanccolatc-acuminate, coriaceous, dceurrent at the base; articulated on a scaly, short, creeping rhizome. Sori medial.

5. C. Decurrens, J. Smith (Polypodiun, Raddi; Campyloneurum, Presl).-An ornamental evergrcen stove species, from Brazil. Fronds glabrous, nearly ovate, pinnate, from two to three feet high, rather erect, with lanceolate-acuminate, narrow, membranous, pale green pinnæ, whieh are six to ten inches long, decurrent at the base, and running down the rachis; they are articulated with a scaly, creeping rhizome. Sori terminal.

\section{NIPHOBOLUS, Kaulfuss.}

Sori round, terminal, sometimes irregular and then usually eonfluent, protruding through dense stellate pubeseenee. Veins pinnate, internal, indistinet; venules parallel, transversely anastomosing, produeing from their exterior side from two to five free or irregularly anastomosing veinlets, whieh are soriferous at their apiees. Fronds simple, from one to one and a-half foot long, thiek and fleshy, or eoriaeeous; the fertile generally eon traeted. Rhizome creeping.-Name derived from niphobolos, eovered with snow; the fronds being eovered with a white starry pubeseenee.

This genus has the most obvious eharaeters of any in this seetion of Polypodiere: for, in the absenee of fruetifieation, it is at onee known by its stellate pubeseenee and simple fronds. The venation being internal and obseure, eannot be well seen, unless the cellular tissue of the frond is destroyed; it is one of the most exquisitcly beautiful of all the forms of venation developed throughout the whole family of Ferns. Fig. 12 represents a fertile and a sterile frond of Niphobolues Lingua (nat. size).

1. N. numulartfolius, $J$. Smith (Aerostrehum, Swartz; Gymopteris, Presl). - A very elegant little evergreen stove species, native of the East Indies and the Philippine Islands. Sterile fronds subrotund, half an inch in diameter, light green, very fleshy. Fertile fronds linear, two inehes long, decurrent at the base. Both the sterile and fertile are articulated on a scaly filiform creeping rhizome. Sori round, subsequently confluent, covering the whole under surface; veins and costa immersed in the substance of the frond.

2. N. Rupestris, Sprengel (Polypodun, Forster; Craspedaria, Link; N. serpens, Endlicher). -A dwarf evergreen greenhouse species, from New Holland. Sterile fronds roundish or oblong-ovate, one to two inches long, decurrent at the base. Fertile fronds linear, three to four inehes long, obtuse at the apex, and decurrent at the base. Both kinds are dull green, and articulated on a small scaly creeping rhizome, about the thickness of a crow's quill. Sori round, coninned to the upper half of tho frond; veins and costa immersed.

3. N. pertusus, Sprengel (PoLypodium, Roxburgh;

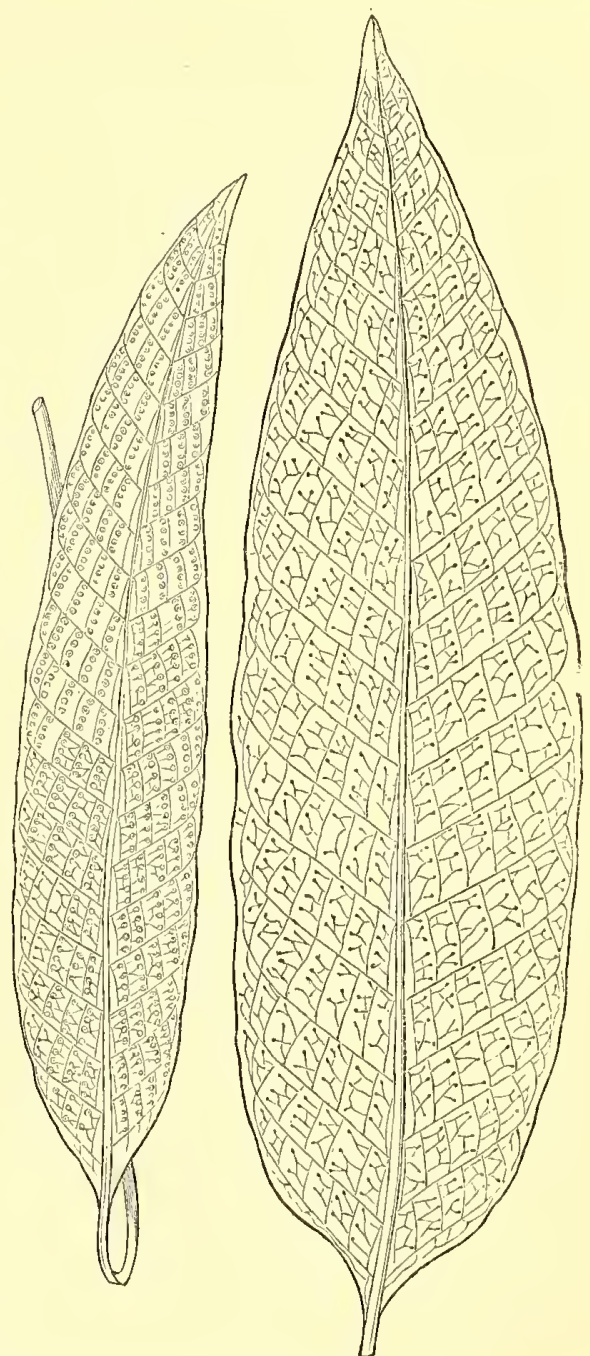

Fig. 12.

Craspedarta, Link). $-\boldsymbol{\Lambda}$ very fleshy evergreen stove Fern, a native of the East Indies, China, and New Holland. Sterile fronds oblong-ovate, obtusc, decurrent at the base, three to four inches long. Fertilc fronds linear, four 
to eight inches long, decurrent at the base. Both are of a light shining green, and are articulated on a small scaly creeping rhizome, of the size of a crow's quill. Sori confluent on the upper half of the frond; veins and eosta immersed.

4. N. varius, Traulfuss.-An ornamental evergreen stove Fern, from the Malay Islands and Singapore. Sterile fronds lanceolate-acuminate, from six to twelve inches long, decurrent at the base. Fcrtile fronds linearlanceolate, acuminate, decurrent at the base, one foot long. Both kinds are densely covered throughout with stellate pubeseence, and are artieulated on a slender scaly creeping rhizome. Sori on the upper part of the frond, confluent in oblong masses ; costa nearly immersed.

5. N. Lingua, Sprengel (Acrostichum, Thunberg; Polypodium, Swartz; Craspedaria chinensis, Linh).A very pretty evergrcen warm greenhouse species, from China and Japan. Sterile fronds lanceolate-acuminatc, six to ten inches long, decurrent at the base, dull green on the upper surface, and whitish beneath. Fertile fronds contracted, but nearly of the same form as the sterile, and of equal length. Both are articulated on a slender scaly creeping rhizome. Sori arranged in transverse parallel rows, between the primary veins, throughout the whole under surface of the frond, brownish red; costa elevated; veins immersed.

\section{PHLEBODIUM, R. Brown.}

Sor $i$ round, oval, or rarely oblong-linear, transversely uniserial or biserial, sometimes irregular. Veins pinnate, or variously branched; venules arcuately or angularly anastomosing, producing on their exterior side, or at their angular junction, two or more conniving veinlets, which are sporangiferous on their combined apices, or line of junction. Fronds simple, pinnatifid or pinnate, from a few

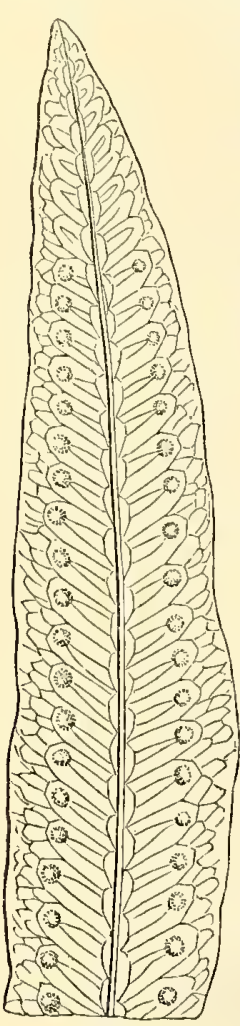

Fig. 13. inches to four feet long, glabrous or squamiferous, coriaceous or membranous. Rhizome creeping.-Name derived from phleps, phlebos, a vein; from the gene-rally conspicuous venation.

The species of Phlebodium resemble some of the Goniophlebiums and Drynarias in habit, and in the circumscription of their fronds. The technical characters by which they are distinguished from other genera are :-the sori being produced on the confluent parts of two or more veinlets, which generally terminate in tho exterior row of areoles; the irregular branching of the veins and venules; and the costal areole being sterile. Fig. 13 represents a portion of a scgment of Phlebodium glaucum (nat. size).

3 AnAfELTIS, $J$. Smith.-Fronds simple; sori without scales.

1. P. squamulosum, J. Smith (Polypodium, Taulfuss; P. mrtillifollum of gardens; Pueopeltis, Presl).-A dwarf crceping evergreen stove Fern, from Brazil. Sterile fronds simple, oblong-elliptical, erect, two to three inches high, dull green, coriaeeous, attenuated at the base, and articulated on a scaly creeping rbizome, of about the thickness of a goosequill. Fertile fronds linear, obtuse.

2. P. venosum, J. H. (Polypodium, Desvaux).-An elegant dwarf evergreen stove species, from South America. Sterile fronds simple, oblong-laneeolate, six to eight inches long, undulated, attenuated at the base, dull green, with conspicuous dark veins. Fertile fronds slightly contracted, linear-lanceolate, attenuated at the base, six to eight inches long. Both forms are scaly on the rachis and stipes, and are lateral, articulated on a creeping scaly rhizome, about the size of a goose-quill. Sori oval or oblong, uniserial.

3. P. lycopodioldes, J. Smith (Polypodium, Limnaus; P. Glabellum, Heward; Pleopelts, Presl). - A very dwarf creeping evergreen stove species, native of the West Indies. Fronds simple, two to four inehes long, oblong-laneeolate, rather obtuse at the apex, attenuated at the base, membranous, undulated, and light green. Sori round, uniserial. Fronds lateral, articulated on a very slender scaly ereeping rhizome.

4. P. Nitidum, J. Smith (Polypodium nitidulum, Kunze).-A dwarf evergreen stove Fern, from Honduras. Fronds glabrous, simple, thrce to six inches long, oblong-elliptical, rounded or obtuse at the apex, attenuated at the base, light green, subcoriaceous and shining. Sori round, uniserial. Fronds lateral, articulated on a scaly creeping rhizome, which is scarccly the size of a goose-quill.

5. P. serpens, J. Smith (Polypodivm, Limneus).-A dwarf creeping evergreen stove Fern, from the West Indies. Fronds simple, glabrous, lanceolate, subcoriaceous, three to nine inches long, of a bluish green, acuminate at the apex, attenuated at the base, entire on tho margin, and decurrent on the stipes. Fronds lateral, indistnictly articulated with a creeping scaly rhizome, about the size of a goose-quill. 
6. P. nitens, $\boldsymbol{M}$. and $\boldsymbol{H}$. - A very slender ereeping evergreen stove Fern, from Sierra Leone. Fronds simple, glabrous, obloug-lanceolate, undulated, four to six inches long, of a bright shining green, often obtuse at the apex, attenuated at the base, entire on the margin, and decurrent on the stipes. Fertile fronds eontracted; lateral, indistinctly artieulated with a slender creeping rhizome, about the size of a crow's quill, which is thickly covered with brown scales. Sori uniserial.

7. P. ovariense, $\boldsymbol{M}$. and $\boldsymbol{H}$. (Polypodium, Desvaux).--An evergreen hothouse Fern, from Sierra Leone. Sterile fronds simple, glabrous, coriaceous, obovate-elliptical, one and a half inch long, sub-sessile, dark green, and entire at the margin. Fertile fronds simple, linear-lanceolate, rather obtuse at the apex, undulated, about two inches long, and entire at the margin. Sori uniserial. Fronds lateral, articulated with a slender creeping scaly rhizome. This species was imported by Mcssrs. Garraway and Mayes, of Bristol, in 1850.

$$
\text { Pleopeltis, J. Smith.-Fronds simple; sori at first covered by the scales of the frond. }
$$

8. P. Pencussum, J. Smith (Polypodium, Cavanillas; Pleopelis, Presl).-An ornamental evergrecn stove species, a native of various parts of South America. Fronds simple, about a foot long, lanceolate-acuminate, cuspidate, coriaceous, bright green, shining, attenuated at the base, and covered throughout with minute peltate fimbriate scales. Sori large, uniserial, seated in dense compact tufts of narrow scales. Fronds lateral, articulated on a scaly creeping rhizome, about the size of a duck's quill.

a Palgedia vera, $J$. Smith.-Fronds pinnatifid or pinnate.

9. P. pecumanum, J. Smith (Polypodium, Willdenow; Pleopeltis, Presl).-A glabrous ornamental subevergreen stove species, from Jamaica, and various places in South America. Fronds slender, light green, somewhat ovate-lanceolate, broad at the base, pinnatifid, two to three feet long, with lanceolate-acuminate membranous segments, which are six to eight inches long, slightly serrated. Sori rouud, immersed, uniserial. Fronds lateral, articulated on a scaly creeping rhizome.

10. P. aurevm, R. Brown (Polýpodum, Linnaus; Pleopeltis, Presl; Chrysopteris, Link).-A noble subevergreen stove Fern, from the West Indies. Fronds glabrous, drooping, somewhat ovate-lanceolate, pinnatifid, three to four feet long, with lanceolate-acuminate broad undulated membranous segments, which are eight to ten inches long, with entire margins. Sori round, biserial, or scattered. Stipes and rachis very smooth, shining, light brown or purple; lateral, articulated on a thick creeping rhizome, densely covered with bright brown scales.

11. P. Sporadocarpum, J. Smith (Polypodum, Willdenow; P. glaucum, of gardens; ? P. areolatum, Tilldenow; Chrysopteris, $\operatorname{Lin} 7)$. - A very beautiful and glaucous evergreen stove speeies, from Mexico. Fronds rather ovate in outline, glaueous throughout, pinnatifid, with stiff, coriaceous, obtuse, almost lanceolate segments, with entire margins. Sori large, uniserial, bright yellowish brown. Stipes very smooth, half the length of the frond, brownish green; lateral, articulated on a thiek glaueous sealy ereeping rhizome.

12. P. multiseriale, $\pi$. and $H$.-A subevergreen hothouse Fern, from South America. Fronds glabrous, subpinnate, two to four feet long, bright green; segments lanceolate-acuminate, rather membranous, nine to ter inches long, dilated at the base, entire at the margin. Sori usually on the upper part, or on distinct fronds, in five to six series on each side the midrib of the segments. Fronds lateral; articulated with a thick creeping rhizome, densely clothed with light brown woolly seales. This Fern was introduced to the Royal Botanie Garden, Kew, in 1850; and has also been reeently introduced from Demarara.

13. P. inequale, $T$. $I I$.-A noble subevergreen warm greenhouse Fern, from Guatemala. Fronds glabrous, broadly lanceolate, wide at the base, three to four feet long, drooping, light green, pinnate; pinnæ lanceolate-acuminate, undulated, rather membranous, six to ten inches long; the inferior petiolate, the superior adnate decurrent and unequal at the base, attenuated at the apex, and slightly crenulate at the margin. Sori large, uniserial, immersed. Stipes smootb, straw-eoloured; lateral, articulated on a thiek scaly ereeping cæspitose rhizome, which is eovered with lanceolate-acuminate scales, broader and less attenuated thau in $P$. aureum, which this plant resembles in general aspect, but from which it differs in being distinctly pinnate, and not at all glaucous. The venation is often that of Goniophlebium. It was imported, about nine years since, by Messrs. Loddiges of Hackney, and is known in gardens under the name of Polypodium triscriale.

\section{XIII, DRYNARIA, Bory.}

Sori round or oblong, naked or squamiferous, produced on the angles or points of eonfluenee of numcrous venules (compital), superficial or deeply immcrsed forming elevated protuberances on the upper surface of the frond; transversely uniserial, or arranged in one or two oblique rows betwcen each two of the primary veins, or irregular. Feins pinnate, parallel, or flcxuose ; venules eompoundly anastomosing, producing from their sides, variously directed, free sterile veinetets, with apices generally rounded or club-shaped. Fronds from a few inches to four or five feet long, simple pinnatifid or pinnate, membranous or coriaceous, glabrous or pilosc. Rhizome creeping.-Name said to be derived from that of the Dryades, nymphs of the woods, in allusion to their native habitation; but more probably from dryinos, of oak, the name having been originally applicd to the oak-leaved $D$. quereifolia. 
The species belonging to this genus have a varied aspect, as well as a wide geographical range; some are very membranous, other's are remarkably rigid in texture, almost without parallel amongst Ferus. Many of the more beautiful species are at present unknown in cultivation. They all have creeping rhizomes, and are well adapted for cultivating on logs of wood, trunks of trees, or amongst light, open materials, where they form very beautiful and highly ornamental objects. Their compound anastomosing venation is met with also in other genera, even in the same section; but the characters that distinguish the Dryuarias from all associates are the naked or squamiferous compital sori, and the compound or zigzag anastomose branching of the veins, with sterile veinlets in the areoles. Fig. 14 represents a portion of Drynaria Billardieri (nat. size).

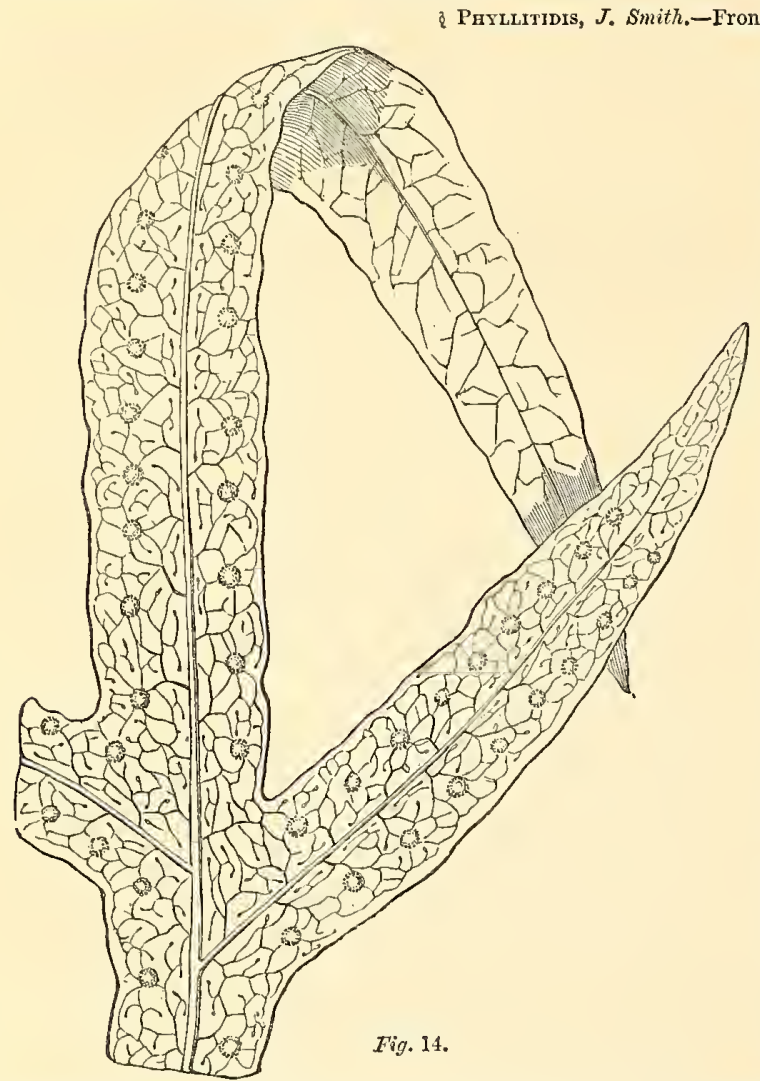

1. D. Fortunis, T. $M$.-An interesting evergreen Fern, from China. Fronds simple, a foot or more in height, lanceolate, attenuated at both the base and apex, subcoriaceous, bright green, entire, or subsinuate, quite smootb, and punctulate with transparent dots, which indicate the apices of free veinlets within the areoles of the veins. Sori distinct, uniserial, near the costa, and chiefly produced a.t the upper part of the frond. Fronds much tapered below into the short, sparingly scaly stipes, which is lateral, and articulated on a slender scaly creeping rhizome. Received from Mr. Henderson, of Wentworth; and precisely accords with No. 18 of Fortune's Chinese plants, collected during his second journey.

2. D. ContiguA, J. Smith (Polypodum, Wallich).-An cvergreen stove species, from Borneo. Fronds simple, glabrous, linearlanceolate, one to one and a half foot long, coriaceous, undulated, deep shining green, acute at the apex, attenuated at the base, decurrent on the stipes, and entire at the margin. Sori oblong, uniserial, submarginal, immersed, forming elevated protuberances on the upper surface. Fronds lateral, articulated with a small creeping rhizome. This specics was introduced by Mr. Low, of the Clapton nursery, in 1847.

3. D. Hemionitidea, J. Smith (Polypodium, Walizch; P. Membranaceum, D. Don; Selliguea hemionitidea, Presl). - A very delicate evergrcen stove species, from the East Indics. Fronds glabrous, simple, one to two feet long, lanceolate, light green, undulated, very membranous, attenuated at the base. Sori round, small, and irregular. Fronds lateral, articulated on a short scaly creeping rhizome.

4. D. irioddes, J. Smith (Polypodiun, Lamarck; P. Polycephalum, Wallieh; Phymatodes irioides, Presl; Microsorum inRegulare, $\operatorname{Lin} i)$.-A glabrous evergreen ornamental stove Fern, native of the Mauritius, East Indies, Sierra Leone, and New Holland. Fronds simple, two to tbree and a half feet long, light green, fleshy, linear-lanceolate, cnsiform, attenuated at the base, and often irregularly lobed at the margin. Sori very small, numcrous, thickly scattered on the upper half of the frond. Venation internal. Fronds lateral, articulated on a short scaly creeping rhizome.

5. D. crassifolia, J. Smith (Polyrodium, Limnaus; Anaxerum, Schott).-A coarse-growing glabrous evergreen stove species, from Brazil, Peru, and the West Indies. Fronds simple, linear-lanceolatc, attenuated at tho base, two to three feet long, and three or four inches wide, coriaccous, dull green. Sori large, round, or oval, uniserial between each two of the primary veins. Fronds lateral, articulated on a short scaly creeping rhizome.

6. D. sesquipedalis, $J$. Smith (Polypodium sesquipedalis, Tallich; Pleopelits nuda, Hookcr). - An evergreen hothouse Fern, from the Mauritius and Nepal. Fronds simple, narrow lanecolate, a foot or more long, light green, undulated, attcnuated at the base, and decurrent on the stipes, acuminate at the apex, cntire on 
the margin, and scattered over beneath with small cordate scales. Sori round, transversely uniserial on the upper part of the frond, immersed, forming large protuberanees on the upper surface. Fronds lateral, articulated with a green creeping rhizome, which is scarcely the size of a goose-quill, and covered with soft seales.

3 Prymatodes, J. Smith.-Fronds pinnatifid or pinnate, all stipitate.

7. D. pustulata, J. Smith (Polypodium, Forster; P. scandens, Forster; P. caspitosum, Link; Campyloneurum c.tspitosum, Link; P. scandens and P. pustulata, Pres $l$ ). $-\Lambda$ dwarf glabrous evergreen greenhouse Fern, from New Zealand. Fronds from a few inches to a foot long, simple lanceolate or pinnatifid with lanceolate-aelminate membranous pale green segments. Sori round, uniserial, and submarginal. Fronds lateral, articulated on a small exspitose creeping rhizome. The simple state is the $P$. cospitosim.

8. D. Bildardieri, J. Smith (Polypodium, Brown; Phymatodes, Presl; Chrysopteres, Link; Polypodium scandens, Labillardiere).-A creeping evergreen greenhouse Fern, native of New Holland, New Zealand, and Van Dicmen's Land. Fronds glabrous, erect, about a foot high, simple or pinnatifid, with a few linear acuminate segments, coriaceous, deep green, attenuated at the base. Sori large, round, uniserial, immersed. Fronds lateral, articulated on a crespitose creeping scaly rhizome, as thick as a goose-quill.

9. D. vulgaris, J. Smith (Polypodium Phymatodes, Limans; P. Pleopeltifolium, of gardons; Phymatodes vulgaris, Presl; Chrysopteris Phymatodes, Liali).-A beautiful evergreen glabrous stove species, native of the Mauritius, New Holland, East Indian and Malay Islands. Fronds rather erect, triangularly ovate, pinnatifid, one to one and a half foot long, decurrent at the base, light green and shining, with oblong-acute eoriaceous segments, four to six inehes long, the lower one often lobed. Sori round or ovate. There are two forms in cultivation. The fronds are articulated on a black sealy creeping rhizome, as thick as a swan's quill.

10. D. longrpes, J. Smith (Polypodium, Link; Chirsopteris, Link; P. alternifolium, Linh). - $\Lambda$ coarselooking evergreen stove Fern, from the East Indies. Fronds glabrous, two to two and a half feet long, pinnatifid, decurrent at the base, coriaceous, with three or four large broad oblong acuminate segments, six or eight inches long, deep green. Sori large, oblong, biserial, immersed. Rachis and stipes pale green; stipes more than half the length of the frond; lateral, articulated on a creeping rhizome, nearly as thick as a swan's quill.

11. D. longrasima, J. Smith (Polypodium. Blume; P. melanoneuron, Miquel; P. melanococca, Hort. Amstel.).-A tall slender evergreen stove speeies, from the East Indies. Fronds glabrous, pinnatifid, two to five feet long, narrow lanceolate, with lanceolate-acuminate membranous undulated distant pale green segments. Sori large, round, uniserial, immersed, forming elevated protuberances on the upper surface of the fronds. Fronds lateral, articulated on a scaly creeping rhizome, which is much elongated, and as thiek as a swan's quill.

12. D. oxylonum, $M$. and $\mathbb{I}$. (Polypopiun, $W$ allich).-A deciduous hothouse Fern, from the East Indies. Fronds glabrous, pinnatifid, decurrent at the base, a foot or more long, somewhat glaucous beneath; segments lanceolate, three to five inches long, acuminate at the apex, entire at the margin. Sori large, uniserial. Fronảs lateral, articulated with a expitose creeping rhizome. Introduced to Kew in 1852. This has an agreeable fragrance like new hay when dry.

13. D: sessilis, $M$. and $H$.-A deciduous stove Fern, a native of the East Indies. Fronds glabrous, lancenlate, pinnate, two feet long, palish green; pinnæ sessile, oblong-ovate, three to six inches long, undulated, acuminate at the apex, roundish at the base, and articulated with the rachis. Sori uniserial. Fronds lateral, articulated with a thickish exspitose creeping rhizome, clothed with narrow-lanceolate seales. This fern is closely allied to the Polypodium venustum of Wallich, but differs in the size and restiture of the rhizome, and in being quite glabrous.

14. D. capitellata, $J$. Smith (Polypodium, Wallich; P. Juglandifolium, D. Don; Phymatodes capitelLata, Presl). - A neat evergreen stove Fern, from the East Indies. Fronds glabrous, pinnate, one to one and a half foot long, with a few oblong ovate mucronate cuspidate membranous pinnæ, which are round at the base and articulated with the rachis, glaucous, with a thickened white margin. Sori large, round, uniserial. Fronds lateral, articulated on a scaly creeping rhizome.

15. D. Leforhiza, J. Smith (Polypodim, Wallich; P. cuspidatum, D. Don; Phy Matodes leiorhiza, Prcsl). -A very ornamental evergreen stove species, a native of Nepal. Fronds glabrous, pinnate, two to three and a half feet long, with lanceolate-acuminate bright green pinnæ, the inferior ones petiolate six to eight inches long, the upper ones adnate and decurrent. Sori round, uniserial, very large. Fronds lateral, articulated on a thick creeping rhizome.

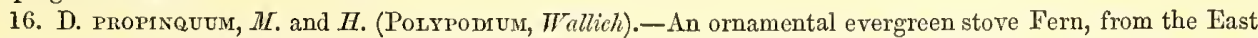
Indics. Fronds glabrous, ovate-lanceolate, pinnatifid or pinnate below, one to one and a half foot long, light green; segments lanceolate-acuminate, three to six inches long, rather membranous, undulated, dilated, and adnate at the base, decurrent on the stipes, and crenately-serrate at the margin. Sori uniserial. Fronds lateral, articulated with a short thickish creeping rhizome, half an inch in diameter, and densely clothed with woolly scales. Introduced to Kew in 1852.

Z DRYMARIA vERE, J. Smith.-Rhizome bearing sessile, sinuose, sterile fronds, with rigid veins.

17. D. miversifolia, J. Smith (Polypodium, R. Brown; P. Glaucrstipes, Wallich). - A beautiful evergreen stove Fern, from the East Indies, Java, and subtropical New Holland. Fronds of two kinds. Sterile fronds sessile, cordate-oblong, pinnatifid, three to four inches long. Fertile fronds slender, stipitate, reclining, one and a half to two 
fcet long, pinnatc, bright grcen; pinnæ scssile, linear-lanceolate acuminate, four to six inches long, and about a quarter of an inch wide, cuneate at the base, crenulate at the margin, and indistinctly articulated with the rachis. Sori uniserial. Fronds lateral, adherent to a thick scaly cxespitose creeping rhizome. Introduced by Messis. Rollisson in 1850.

18. D. quercifolia, J. Smith (Polypodium, Linnaus; Phymatodes, Presl).-An evergreen stove Fern, having an extensive geographical range through the tropies of the eastern hemisphere. Fronds of two kinds: sterile-scssile, oblong-ovate, cordate at the base, sinuose or laciniated, with the vascular structure rigid, and permanent: fertile-stipitate, pinnatifid, with linear acuminate undulated segments, having a thick margin, and articulated with the rachis. Sori round, obliquely and rather irrcgularly disposed throughout the whole under surface of the frond. The rhizomes are thick, scaly and creeping. There are various well-defined forms of this specics distributed throughout the Eastern hemisphere.

19. D. cononans, $M$. and $H$. (Polypodium, Wallich; Phymatodes, Presl).-A noble evergrcen stove Fern,

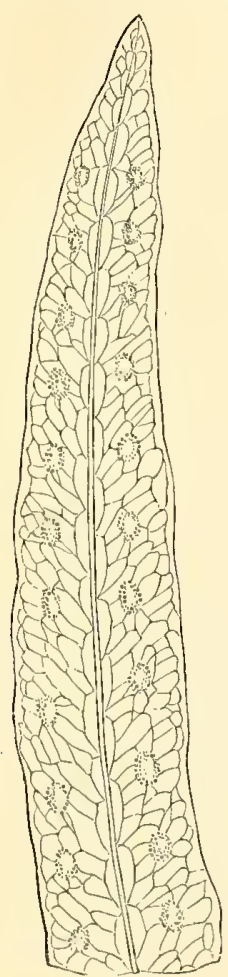

Fig. 15. native of the East Indies. Fronds glabrous, rigid, sessile, rather erect, cordate-oblong, three to four feet long, lightish green, deeply pinnatifid; segments oblong, undulated, articulated with the rachis, lower ones round at the apex, upper ones acuminate, margin thick and cntire. Sori uniscrial, between each two of the primary veins, and confined to the upper half of the frond, which is lateral, adherent to a thick decumbent fibrose slightly creeping rhizome.

\section{DICTYMIA, J. Smith.}

Sori oblong, compital, transversely uniserial, reccptacle immersed. Tenation uniform, reticulated, internal. Fronds simple, glabrous, coriaccous. Rhizome creeping.-Name derived from ditityon, a net; alluding to the netted renation,

This genus is established on habit more than any technical characters. The two species which it comprises are natives of New Holland and New Zealand. Their uniform reticulated venation distinguishes them from Drynaria, the areoles being all sterile. Fig. 15 represents the upper part of a frond of Dictymia attcnuata (nat. size).

1. D. attenuata, $J$. Smith (Polvpodium, Brown; P. Brownlanum, Sprengel ; Dictyopteris, Presl).-An ornamental evergreen greenhouse Fern, from New Holland. Fronds simple, linear-acuminate, dark green, about a foot long, coriaceous, attenuated at the base. Sori oblong, uniserial, on the upper half of the frond. Fronds lateral, articulated on a creeping rhizome, nearly as thick as a goose-quill.

\section{DRYMogLossum, Prest.}

Sori linear, continuous, marginal or intramarginal, produced on the transverse sides and junctions of the venules, forming a broad marginal or intramarginal soriferous band, which is pilose or squamifcrous. Tenation uniform, compoundly anastomosing, producing variously directed free veinlets. Fronds simple, elliptical, or lanccolate, coriaceous, from one to sixteen inclies long. Rhizome crceping.-Name derived from drymos, a forest, and glossa, a tongue ; alluding to the form of the fronds, and the

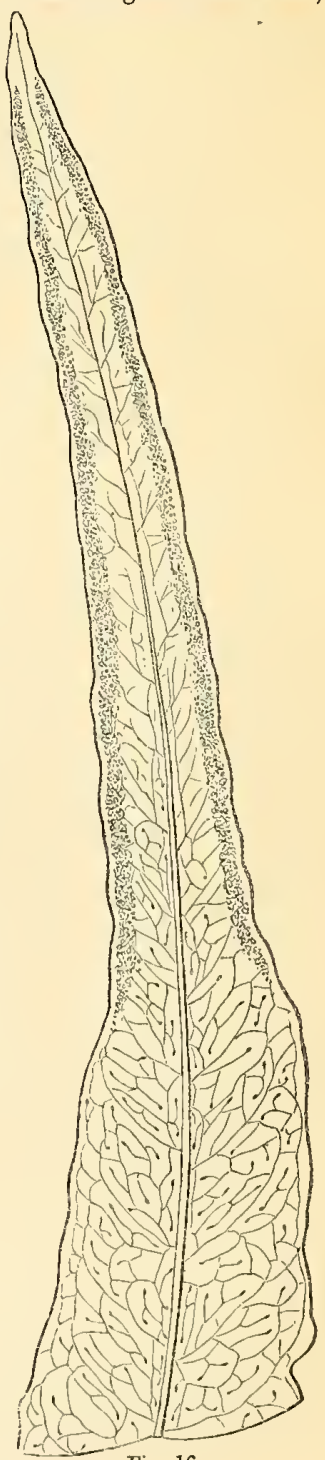

Fig. 16. native habitat of the plants.

Comparing the venation in this genus with what oecurs in Drynaria and Sellignea, it is only by the position of the linear continuous sori that it is distinguishable. The essential eharacters are a com- 
pound anastomosing venation, with the naked linear eontinuous sori running parallel with and near to the margin. Fig. 16 represents the upper portion of a frond of Drymoglossum lanceolatum (nat. size).

1. D. Piloselloides, Presl (Pteris, Linneus; Pteropsis, Desvaux; Nothochlæna, Kaulfuss).-A dwarf creeping evergreen stove Fern, native of the East Indies and Malay Islands. Fronds of two kinds: sterileclliptical or roundish-ovate, one inch high, attenuated at the base: fertile-linear, narrow, two inches high, attenuated at the base; both are lateral, articulated on a filiform creeping rhizome. Sori confluent, covering the whole surface of the frond. This Fern is at present extremely rare in cultivation, although in 1843 it was covering the end of a pine stove in the garden of the Duke of Nortbumberlaud, at Syon.

2. D. lancelatum, $J$. Smith (Pteris, Linnous; Pteropsis, Desvarex; Thenitis, Kaulfuss).-An ornamental evergrecn stove Fern, from Jamaica. Fronds uniform, lanceolate, from ten to sixtecn inches long, contracted at the apex where they are soriferous, pale green and attenuated at the basc; they are lateral, articulated on a slender slowly creeping rhizome. Venation internal.

\section{TANIOPSIS, J. Smith.}

Sori linear, eontinuous, immersed in an intramarginal groove. Veins simple, parallel, their apices combined, and forming a transverse sporangiferous reeptacle. Fronds simple, linear-lanceolate, one to two feet long, plane or with the margin revolute--Name derived from tainia, a fillet or band, and opsis, resemblance, from the long narrow outline of the fronds.

In habit, venation, and external appearanee, the species of this genus are precisely identical with Vittaria; the only grouud on which they are separated is the position of the sporangiferous receptacle, which in Iittaria is marginal, and in Teniopsis is intramarginal. Fig. 17 repre-

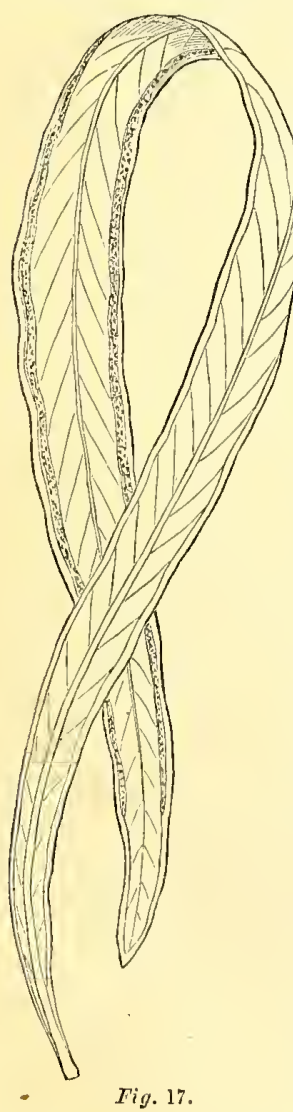
sents a frond of T'aniopsis graminifolia (med. size).

1. T. uineata, J. Smith (Vittaria, Swartz).-.A singularly narrow evergreen stove Fern, from the West Indies. Fronds simple, glabrous, pendulous, one to two feet long, and about an eighth of an inch broad. Veins internal, and very few; costa obsolete. Fronds lateral, forming a dense mass on a short creepiug scaly rhizome. Sori intramarginal, in a groove nearly the whole length of the frond.

2. T. graminifolia, J. Smith (Vittaria, Kaulfuss).An ornamental evergreen species, from the West Indies. Fronds simple, glabrous, rather erect, about ten inches high, lanceolate-acuminate, undulated and attenuated at the base. Sori submarginal, continuous or interrupted, and confined to the upper half of the frond. Venation iuternal.

XVII. VITTARIA, smith.

Sori linear, continuous, immersed in a marginal groove. Veins simple, parallel, combined at their apices by a transverse marginal vein, on which is produced the sporangiferous receptacle. Fronds simple, linear-elongate, from one to four or five feet long. Rhizome ereeping.-Name derived from ritta, a ribband; which the long narrow fronds resemble.

This genus consists of a few narrow-fronded

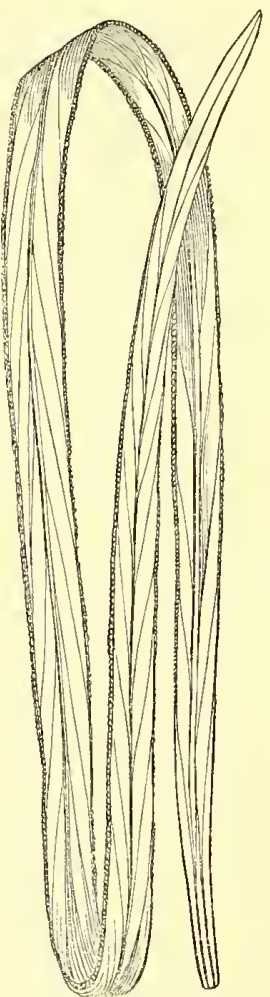

Fig. 18. grassy-looking tropical Ferns, and originally comprised ten or twelve species. In aspect, habit, and venation, they coincide with Taniopsis, from which, on aceount of the variation in the position of their sori, they have been divided. The species of Vittaria have their sori in the edge of the frond, opening outward; whilst those of Taniopsis have their sori medial or intramarginal, in the plane under surface of the frond. In both cases the sori are immersed in grooves. Fig. 18 represents a small frond of Vittaria zostercefolia. 
1. V. zosterderolia, Willdenow (V. angustifrons, Bory).-A pendulous-growing evergreen stove Fern, from the Mauritius. Fronds simple, glabrous, subeoriaceous, from one to four feet long, and about a quarter of an inch wide, of a rather bright green. They are lateral, adherent to a small creeping rhizome, densely covered with dark scales. Venation internal; eosta within the substance of the frond. This species was introduced to Kew in 1852.

\section{XVIIT. ANTROPHYUM, Kaulfuss.}

Sori linear, continuous or interrupted, reticulated; sporangiferous receptacle immersed in the sub-

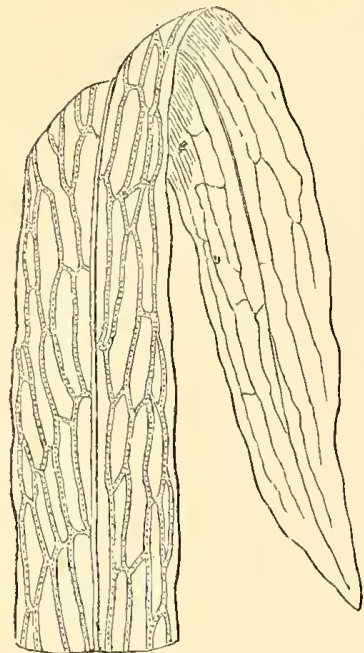

Fig. 19. stance of the frond. Venation uniform, reticulated; sides of the areoles more or less sporangiferous. Fronds simple, lincar-lanceolate or elliptical, coriaceous.-Name derived from antron, a cavern, and phyo, to grow; alluding to the hollows on the under surface of the fronds, from whence the sporc-cases arise.

The character which distinguishes this genus from IIemionitis is the immersed sporangiferous receptacle; the sori of Hemionitis being superticial, Fig. 19 represents the upper portion of a frond of Antrophyum lanceolatum (nat. size).

1. A. Lanceolatun, Kaulfuss (Henionitis ranceorata, Limnaus.-A delicate evergreen stove species, from the West Indies. Fronds simple, glabrous, one foot long, linear-lanceolate, acuminate, attenuated at the base, slightly undulated, and of a light green eolour. Fronds lateral, somewhat fleshy, forming a dense tuft on a short crceping rhizome. Venation internal.

\section{HEMTONITIS, Limnaus.}

Sori linear, reticulated, superficial, and subscquently confluent. Tenation uniform, reticulated, sporangiferous on the sides of the areoles, which are nearly equal. Fronds simple, cordate palmate or pinnate, glabrous or villose.-The name was used by Dioscorides, and is said to be derived from hemionos, a mule, from the supposed sterility of the plant. In this sense, howcver, the name is here obviously misapplied; for in addition to the ordinary method of propagation by spores, $I$. palmata is viviparous, and increases readily by this means also.

The species of IIemionitis are exeeedingly beaxtiful, of dwarf habit, and among the most interesting of all dwarf Ferns. 'The character by which they are at onee recognised, is the superficial reticulated sori. Fig. 20 represents a frond of Hemionitis palmata (med. size).

1. H. palmata, Linnous.-A very elegant evergreen stove Fern, fiom Brazil and the TWest Indies. Fronds hairy, nearly one foot high, eordate and palmate, with five oblong-obtuse or acuminate segments, crenulate or bluntly lobed. Fertile fronds erect, the sterile ones nearly horizontal, both proliferous in the sinuses; terminal, adherent to a faseiculate rhizome. 
2. H. eoRdita, Roxburgh.-A beautiful low-growing evergreen stove Fern, from the East Indies. Fronds simple, cordate, hairy, espeeially on the rachis and nargin; the stcrile ones deep green, four to six inehes long, roundish at the apex; the fertile ereet, eordate-sagittate or suh-trilohate and triangular, six or eight inches high. Stipes ehencous. Fronds terminal, adherent to a small tufted rhizome. This Fern was raised at Kew, in 1852, from spores, but has not yet produeed fructification.

\section{CERATOPTERIS, Brongniart.}

Sori linear, continuous, parallel, supcricial, produced on the lengthened transverse sides of the renules, and concealed by the reflexed margin of the segments. Teins transversely elongated, and distantly anastomosing. Fronds flaceid, of two kinds : sterilc-pinnatifid or bipimnatifid, sinuate and viviparous; fertile-contracted, decompound, membranous, multifid, with linear forked and viriparous segments having their margins reflexed and indusiform.-Named from keras, keratos, a horn, and pteris, a fern; alluding to the fertile fronds.

The peculiar habit and structure of this genus render it difficult to deter. mine its real affinity. The spore-cases are scssile, large and globose, furnished either with a broad nearly complete, or very short nearly obsolete ring. It was originally associated with Glcicheniaceer. Fig. 21 represents portions of the sterile and fertile fronds (nat. size), with a portion of the fertilc frond magnified, showing the position of the sori.

1. C. Thalietromes, Brongniart (Elloboearpus oleraceus, Foulfuss). - A very singular annual aquatie stove Fern, native of the tropies of both hemispheres. Fronds glahrous, of two kinds : sterile-hipinnatifid, one to one and a half foot long, reelining, with oblong obtuse segments; fertile

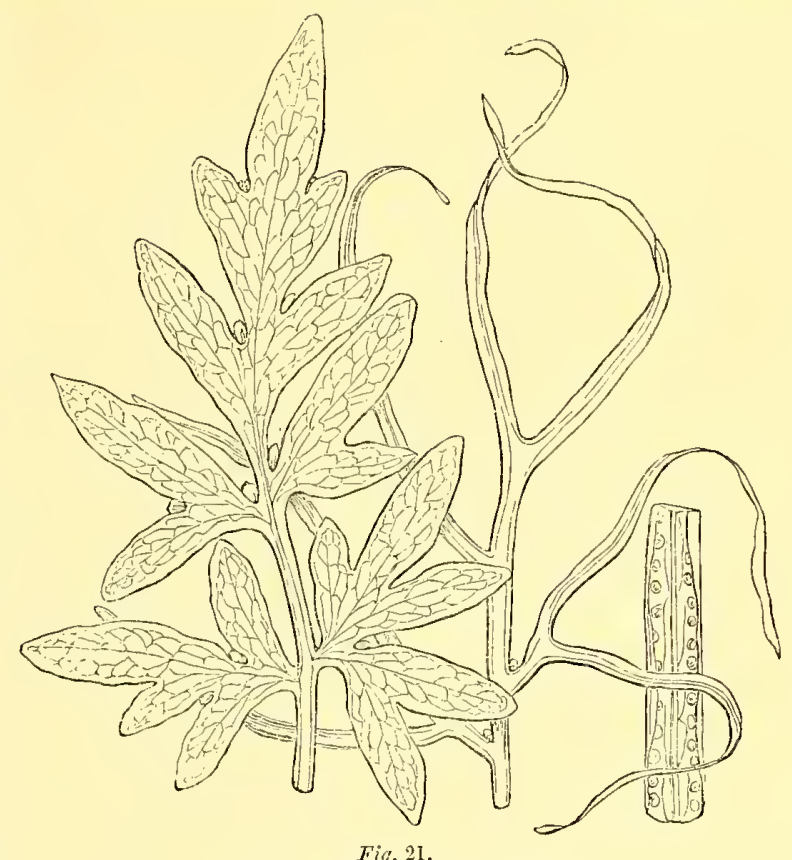

Fig. 21 . - eontraeted, ereet, three or four times pinnate, one and a lralf to two and a half feet high, with linear revolute segments. Both forms are viviparous, of a light green, with the stipes nearly quadrangular.

C. Parkeri, J. Smith (Parkeria Pteroides, Hooker and Baucr), was raised hy Mr. H. Shepherd, of Liverpool, and so elosely resembles the Ceratopteris thalictroides, in all respeets except the elastie ring of the spore-ease, that it is only to he diseriminated by the aid of a very powerful mieroseope. Mr. J. Smith informs us that he has raised $C$. thatietroides from the spores of this supposed speeies.

Tribe Acrostichex, J. Smith.--Sori amorphous, without an indusium.

The species forming this extensive natural group are probably the easiest of all Ferns to rccognize, from the sori being spread generally througbout the under surface of the frond. The speeics were originally comprehended under two or three genera; but they have been subdivided into nearly twenty. They have distinct sterile and fertile fronds, in which respect they are similar to Lomaria, in the tribe Pteridece, but they are at onee distinguished from that group by the absence of an indusium, with whieh the Lomarias are furnished. Their most obvious point of distinction from Polypodiea is in the sori being amorphous; that is, not produced in round or linear masses, but closely occupying an irregular portion or the whole of the fertile disk, which in one or two genera is not confined to the inferior surface alone, the contracted rachiform segments being sporangiferous on both sides. 


\section{ELAPIIOGLOSSUM, Schott.}

Sur i amorphous, thickly covering the whole under surface. Teins simple or forked, internal; re:zules parallel, their apices free and clavate, terminating within a thickened margin. Frouls simple, from a few incles to two feet long, linear-laneeolate, eoriaceous, glabrous, pilose, or squamose.-Named from claphos, a deer, and glossa, a tongue; the small simple fertile fronds being supposed to resemble the tongue of the deer. In most modern catalogues the name is strangely enough said to be derived from elephas, an elephaut, and glossa, a tongue-elephant's tongue!

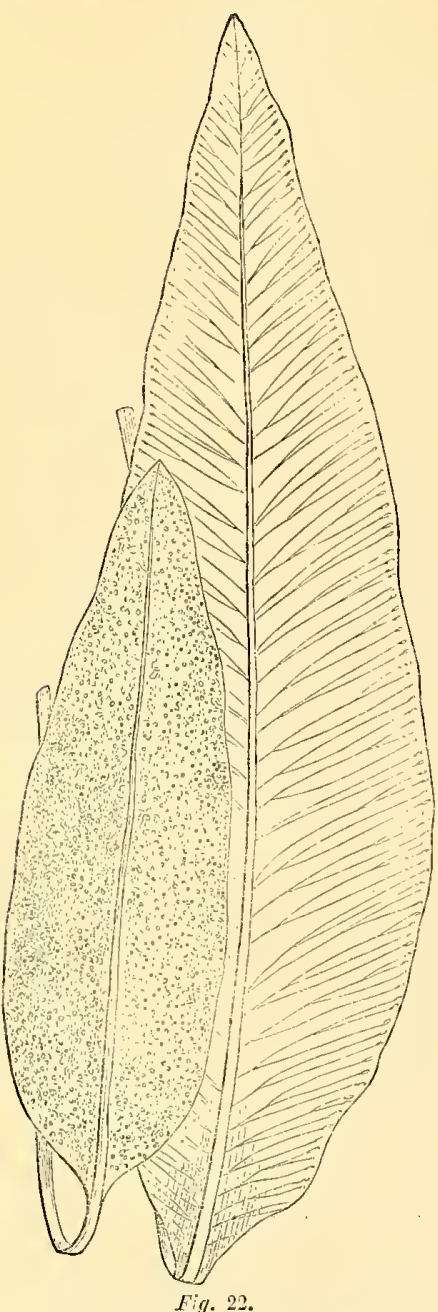

This genus is readily distinguished from its eongeners by having simple fronds, with forked free veins. Fig. 22 represents a sterile and fertile frond of Elaphoglossum conforme (med. size).

1. E. coxtorue, J. Smith (Acrostichuy, Swartz; Olitersta, Presl). -An erect dwarf evergreen stove Fern, from the Cape of Good IIopc. Sterile fronds glabrons, oblong-acuminate, attenuated at the base, from six to twelve inches high, coriaceous, deep green. Fertile fronds small, ovate or oblong-acuminate, from six to ten inches high. Both forms are articulated near the rhizome. This species attains the height of a foot and a half in its native locality. Rhizome scaly and cæspitose, creeping.

2. E. clinsinfive, $M$. and $I I$. (Acrostichux, Kunze). -An evergreen stove Fern, from the West Indies. Sterile fronds glabrous, oblong. ovate, bluntly acuminate, from twelve to eighteen inches long, attenuated below and decurrent on the stipes, thick and coriaceous, undulated, dull green. Fertile fronds oblong-ovate, one foot high, attenuated at the base. Both forms are articulated near the base of the stipes, and are lateral on a short creeping scaly rhizome.

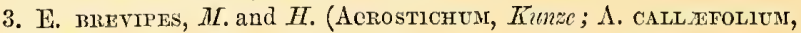
Link, not Blume-fide Tínze; E. CALt_EFoLivM, J. Sinith).-A glabrous evergreen stove species, from Java. Sterile fronds oblong-ovate or ovatelaneeolate, a foot or more long, coriaceous, deep green, shining, undulated, roundish or somewhat attenuated at the base. Rachis and stipes dark purple beneath. Fertile fronds crect, ovate-clliptical, acuminate, one foot or more high. Both forms are articulated near the rhizome, which is scaly and ereeping.

4. E. longmotinus, J. Sinith (Acrostichux, Jacquin; OtfersiA, Presl; Candollea, Mirbel; Aconiopteris, Fee; A. Latifoliust, Sucrtz). - A glabrous evergreen stove Fern, from the West Indies. Sterile fronds coriaceons, bright green, lanceolate-acuminate, one to onc and a half foot long, slightly undulated, attennated at the basc. Fertile fronds erect, lanceolate-acuminate, one to one and a half foot high, attenuated at the base. Both articulated near the base of the stipes; lateral, on a scaly cæspitose creeping rhizome.

5. E. scolopexdrifolidu, J. Smith (Acrostichum, Raddi; Olitersis, Presl). - An ornamental evergreen stove species, from Brazil. Sterile fronds lanceolate, acuminatc, twelve to fifteen inches long, undulatcd, pale green, with stipes one third the length of the frond; stipes, rachis, and margin of frond covered with fimbriate-acuminate cordate brown scales. Fertile fronds small, erect, lanceolate, acuminate, one foot lovg, with a stipes eight inches long. Both forms are articulated near the base of the stipes, and are lateral, on a very short scaly ereeping rhizome.

6. E. villostu, J. Smith (Acrostichuxi, Swartz; OLFERsia, Presl).--[Plate III]-An ornamental evergreen stove Fern, from Jamaica. Sterile fronds hairy, lanceolate, acuminate, undulated, pale green, about a foot long. Fertile frond narrow, lanceolate, acuminate, eight inches long. Both forms are articulated near the base of the stipes, and are lateral, on a very short creeping scaly rhizome.

7. E. cuspidatum, $M$. and $H$. (Acrosticium, Willdenow; Otfersia, Presl). $-\Lambda$ dwarf evergreen hothouse Fern, from South America. Sterile fronds linear-lanceolate, aeuminate, from cight inches to a foot long, and nearly an inch wide, of a dullish grecn, attenuated at the base, and thickly covered, especially on the upper surface, with stellate or fimbriate scales. Fertile fronds of the same form as the sterile, but narrowcr, nearly a 
foot long, with stipes nearly half their length. They are lateral, indistinetly artienlated with a slender creeping: rhizome. This plant was introdueed in 1851 , and was then referted to $E$. Dombeyanzm, Fee.

8. E. strictum, T. $M I$. (Acrostichum, Raddi; Orfersid, Presl). $\mathrm{A}$ delicate little stove species, rcceived from Wentworth, whieh we refer to $A$. strictum of Raddi, a native of Brazil. Fronds small; the sterile ones four or five inches long, linear-lanceslate, narrowed above in a long point, and below into a short scaly stipes, the upper surface clothed with silvery scales, the lower more denscly with tawny seales, the seales lanceolate, and strongly ciliate. 'The fertile fronds are lineal' oblong-obtuse, narrowed below in a long slender stipes, which is twice their length, and almost equalling the barren fronds; upper surface densely lepidote with ferruginous seales, lower with a sealy nidrib.

9. E. himtum, $\lambda$. and $I T$. (Acrostichum, Swartz; A. vestisum, Lowe; A. Loweanum, Irunzo ITerb; Ulfersta vestita, and O. Pulface, Presl).--An evergreen warm greenhousc Fern, from Madeira. Sterile fronds linear-laneeolate, about a foot long, acute at the apex, attenuated at the base, and densely covered throughout with ciliated seales. Fertile fronds lancelate, about a foot long, rather obtuse at the apex, attenuated at the base. Stipes elongate, and densely scaly. Fronds lateral, artieulated near the base, with a short ereeping sealy rhizome.

\section{S'TENOCHLANA, J. Smith.}

Sori amorphous, densely eovering the under surface of the fertile fronds. Trins (sterile) simple or forlsed, external; renules parallel, their apiees exserted, forming eartilaginous scrratures, or eonniving and forming a thickened margin. Rachis-like part of rhizome, sometimes prorlueing abnormal tripinnatifid sterile fronds. Fronds pinnate, or bipinnate, from one to four feet long, glabrous or squamose. Pinnules (fertile) linear, narrow, the margin membranous, revolute and indusiform. Rhizome creeping.-Name derived from stenos, narrow, and ellaina, a cloak; alluding to the narrow membranous margin of the fertile pinnze.

The species of this genus have a distinet and peculiar aspeet, and form a very natural group. In habit they resemble Polybotrya, having a ereeping sealy rhizome. 'I'he narrow linear segments of the fertile frond, with their indusiform margins, are analogous to what oceurs in Lomaria; but they differ materially from that genus in the mar.rin being revolute, whereas in Lomaria it is plane, and usually the axis of an indusium. Fig. 23 represents a pinna of the sterile frond, with part of a pinna of the fertile frond of Stenochlera scandens (med. size); for the latter we are indebted to Mr. Henderson, gardener to Earl Fitzwilliam, at Wentworth House, Yorkshire.

1. S. scaxdexs, J. Smith (Acrostrchum, Linnans; Lo. mar1a, Tilldenow; OLrmesia, Presl; Oxociea, Swarta).-An clegant evergreen stove Fern, with a seandent habit of growth, native of the East Indian and Malay Islands, and the Cape of Good Hope. Sterile fronds glabrous, shining, lanecolate, pinnate, somewhat pendulous, from three to four feet long; pinnæ linearacuminate, euneate at the base, rather membranous, nearly a foot long, with a serrated eartilaginous margin; veins simple or forked, parallel, connected at the base by arcuate eostal veins, forming a row of loug narrow areoles close to the midrib. Fertile fronds bipinnate; pinnæ six to eight inches long; pinnules lincar, narrow, and sporangiferous on the under surface. Both kinds of fronds are lateral, adherent to a scandent slender green

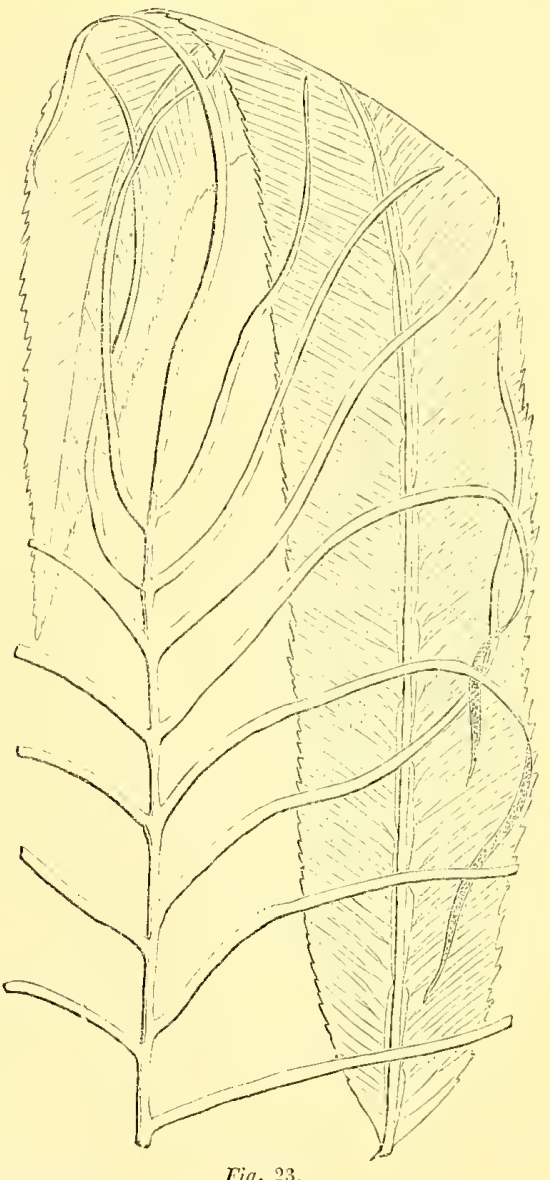
rhizome, which is covered with long narrow seales, attached by their centre.

2. S. Loxglfotı, J. Smilh (Loxaril, Kaulfuss). - An ornamental evergreen scandent stove Fern, from Guiana and the Trest Indies. Sterile frouds glabrous, pinnate, one and a half foot long; deep green; pinnse 
ovate or oblong, lanceolate, sessile, acute or acuniunte at the apex, obtusely cuneate at the base, entire on the margin, and articulated with the rachis. Fertile fronds glabrous, pinnate, about a foot long; pinnæ linearlanceolate, the terminal one elongate. Fronds lateral, adherent to a seandent rhizome.

3. S. sorbirolis, J. Sinith (Acrostienum, Limeers), - A dwarf evergreen seandent stove Fern, from Jamaica. Sterile fronds glabrous, lanceolate, pinnate, about a foot long, with ovate or oblong acuminate, undulated, coriaccous, shining, bright green pinnæ, which are obtusely cuneate at the base, and articulated with a winged rachis. Fertile fronds erect, one foot high, pinnate, the pinne entire and articulate with the rachis. Botl are latcral, adherent to a sealy creeping rhizome, about the size of a goose-quill.

\section{xXIII. POLYBOTRYA, ITumbolut and Bonp?}

Sori amorphous, oeeupying one or both sides of the spiciform segments of the eontraeted fertile frond. Teins pinnate; venules simple, free, external. Fronds bi-tripinnate. Rhizome ereeping.-Named from polys, many, and botrys, a raceme; alluding to the appearanee of the fertile frond.

This genus, in habit and venation, is similar to Stenochlena, but is separated ehiefly on aceount of the formation of the fertile fronds. From Elaphoglossum it is distinet in habit, although somewhat analogous in venation; distinguishable, howerer, by the veins being external, those of Elaphoglossum being internal. There are many speeies of Polybotrya, all tropical; but one only is in eultivation. Fig. 24 represents a pinnule of the sterile frond, and the npper portion of the fertile frond, of Polybotrya cylindsica.

1. P. cylindries, Táulfuss (P. speciosa, Schott).-A rather coarse-looking seandent evergreen stove Fern, from Jamaica and South America. Sterile fronds glabrous, triangularly elongate, bi-tripinnate, from two to three feet long, bright shining green; pinnules oblong-acuminate, pinnatifid, truncate at the base, with obtuse seg. ments, the one next the rachis largest on the upper side, and erenately-serrate on the margin. Fertile fronds contracted, of the same form as the stcrile, bi-tripinnate, from one to two feet long, and sporan. giferous throughout, with the segments eylindrical. rlizome.

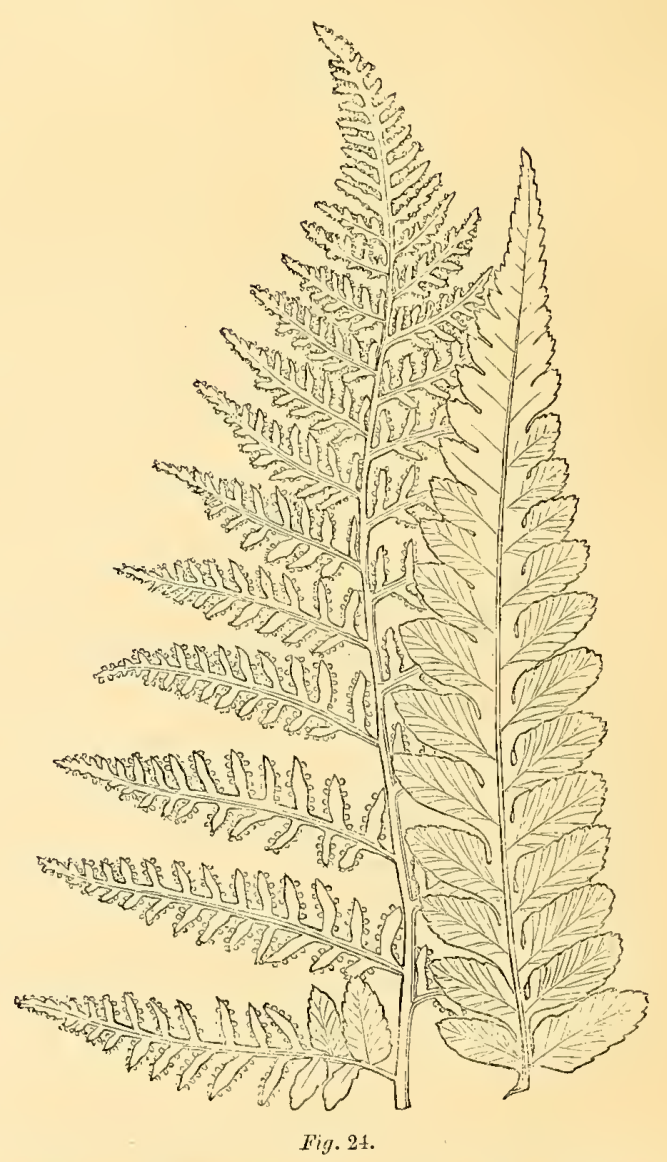

Both forms are lateral, adherent to a rough scaly crecping Sect. Srmpiopillerie., J. Smith.--Yeins netted, or variously anastomosing.

\section{OLFERSIA, Raddi.}

Sori amorphous, densely eovering the segments of the fertile frond throughout. Teins forked, parallel, internal, their apiees combined by a transverse eontinuous margiral vein. Fronds pinnate. Pilizome ereeping.-Name probably commemorative of Olfers, which is the name of a German writer, but we do not find it explained.

Of this very elegant genus only one speeics is known. The venation is not very rendily seen in the fertile fronds, in eonsequenee of its being. eontraeted and sporangiferous on both sides; but in the 
sterile fronds, where it is evident it indieates a deeisive eharncter, by which the genus may be readily distinguished-namely, a eontinuous marginal transverse vein, conneeting all the oblique veins by their apices. Fig. 25 represents a pinna of the sterile frond, and a portion of the fertile frond of Olfersia cerrina (med. size).

1. O. eervina, Presl (Acrostichum, Suctiz; Polybormy, Kaulfuss) - - A very elegant evergrecn stove Fern, from the West Indies. Sterilc fronds glabrous, lanceolate, pinnate, reclining, from two to thrce feet long; pinnæ oblong-acuminate, coriaccous, bright green, rounded at the supcrior base, the inferior truncatc. Fertile fronds erect, bipinnate, from two to threc feet long; pinnæ linear, sporangiferous throughout; stipes covered with long narrow scales. The fronds are terminal, adberent to a thick short crecping scaly rhizome.

The fertile frond of this spccies is usually bipinnate; when pinnate only, it is the $O$. eorcovadensis of Raddi. We have both forms, gathered at the same time from onc plant; they are, conscquently, mcrely accidental modifications of onc specics.

\section{XXV, ANETIUM, Splitycrber.}

Spore-eases few, irregularly seatiered through-

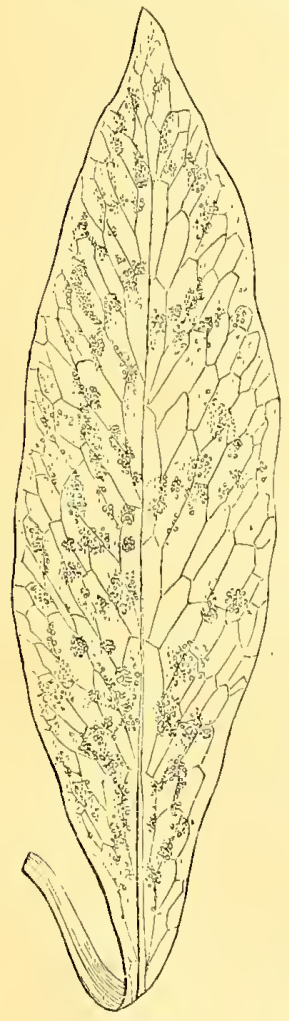
out the under surface of the fronds, often colleeted in small groups or lines. Venation uniform, retieulated, the areoles elongated. Fronds simple. Rhicome ereeping.-Name derived from anetos, lax; alluding to the sori being sparse and seattered.

The habit of this genus (whieh eontains but one

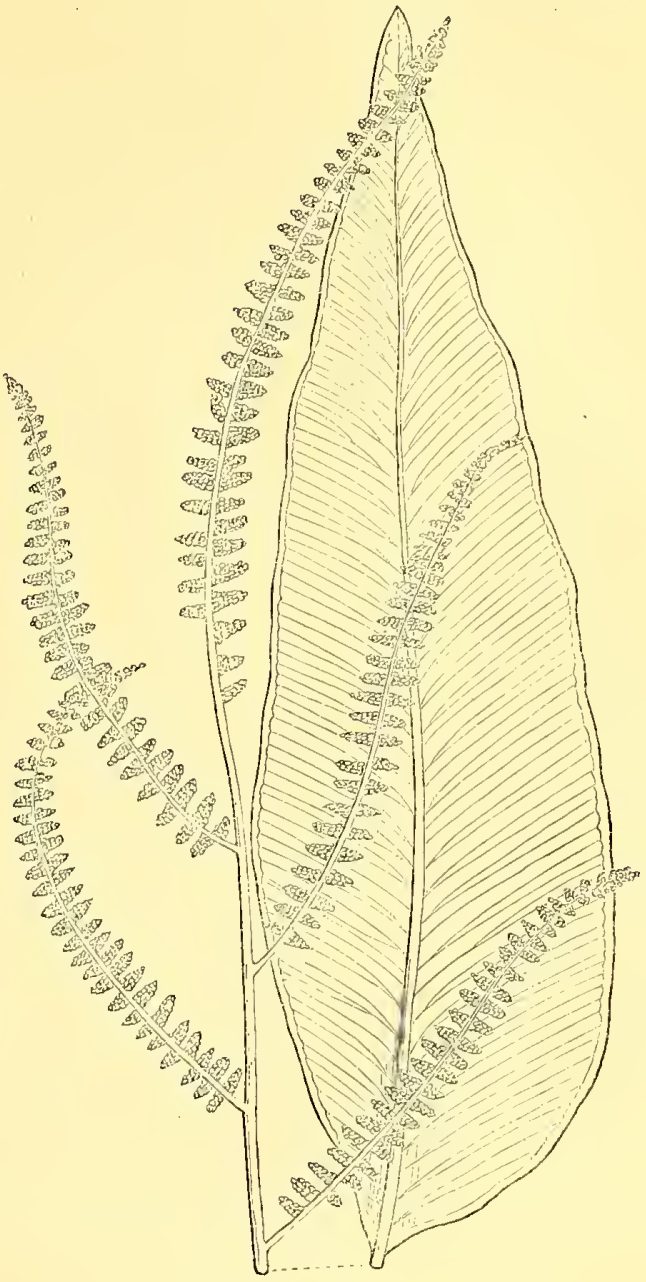

I'ig. 25. speeies), and its fow scattered sporangia, are the eharneters by which it is separated from Acrostichum. Fig. 26 represents a frond of Anetium citrifolium (med. size).

1. A. eitrifolium, Splitgerber (Aerostienum, Linnens; Antrophyusi, Fee). -A dwarf ornamental cvergreen stove Fern, from the West Indies. Fronds simple, uniform, glabrous, somewhat membranous, oblong-elliptical, attenuated at the base, six to ten inches long; latcral, articulated with a sealy fibrous erecping rhizome. Sori irregularly scattered.

\section{HYMENODIUM, Fee.}

Sori amorphous, densely eovering the under surface of the fertile frond. Tenation uniform, internal, retieulated, forming large elongated arểeles. Fronds simple, one foot or more in length, hairy. Rhiromo ereeping, and densely eovered with hair-like scales.-Name derived from hymen, a membrane; from the membranaeeous texture of some of the species. 
This genus differs from Acrostichum in habit more than in technical characters. Its nearest affinity is with Ancticm, which it resembles in habit, having simple fronds and a creeping rhizome ; but it is

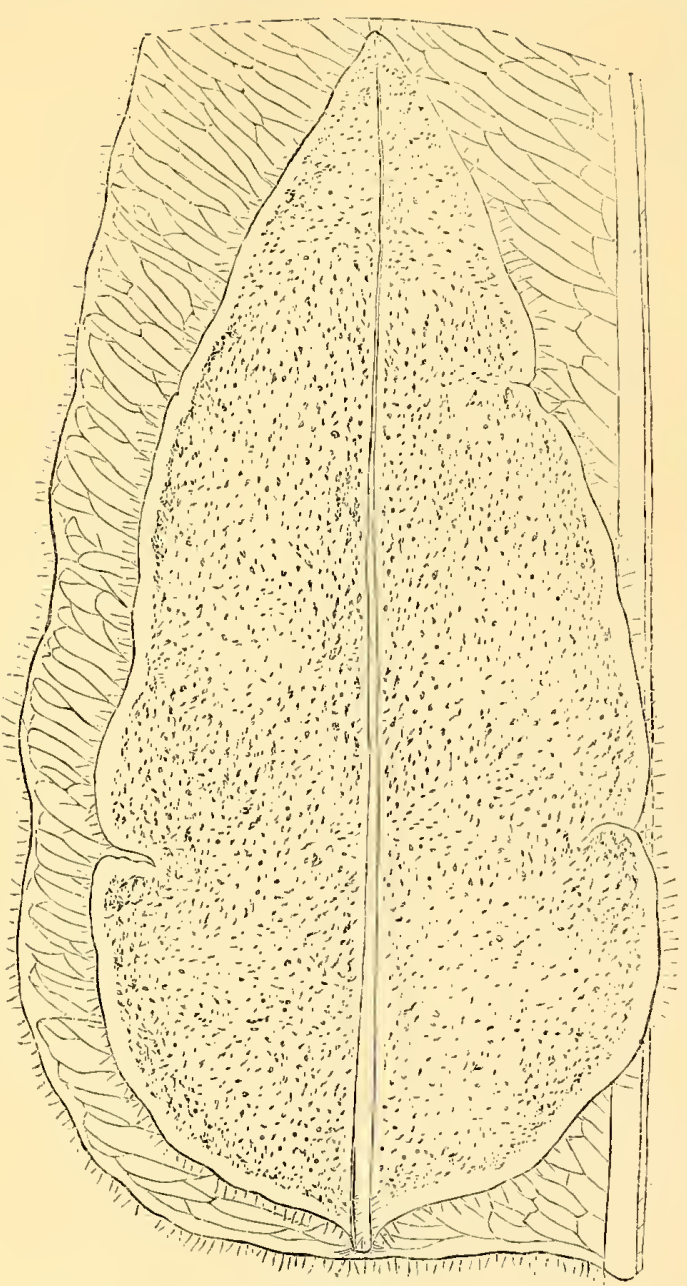

Fig. 27.

are terminal, adherent to a thiek creeping rhizome, which is densely eovered with criniform scales.

\section{XXVIr. ACROSTICHUM, Linneus.}

Sor $i$ amorphous, universal on the under surface of the fertile frond. Tenation uniform, reticulated, forming elongated arcoles.-Named from akros, high, and stichos, order; the fructification occupying the upper portion of the fertile disk.

'The species belonging to this group are but few in number, all tropical plants, and varying from six to eight feet in height. The technical characters by which the genus is distinguished are :- the uniform reticulated venation, and crect caudiciform rhizome. Fir. 28 represents a pinna of the sterile and fertile fronds of Acrostichum aureum (med. sizc). separated by the dense amorphous sori, the sori in Anetium being few and irregularly scattered, while in Irymenodium they denscly corer the whole under surface, except the margin. Fig. $27 \mathrm{r}$ represents a fragment of the sterile, and a fertile frond of Irymenodium crinitum (less than half the nat. size).

1. H. crintruir, Fee (Acrostrehum, Limneus Oxfersil, Presl; Dietroglossum, J. Smith).-An vergreen stove Fern, with a very peculiar aspeet; a ve Jamaiea. Sterile fronds simple, ovalnd eight to ten inches wide, dull green, and hairy oughout. Fertile fronds simple, erect, ovalhigh, with a stipes of six to nine inehes, densely overed, as well as the upper surface of the frond with long narrow black hair-like scales. Buth forms

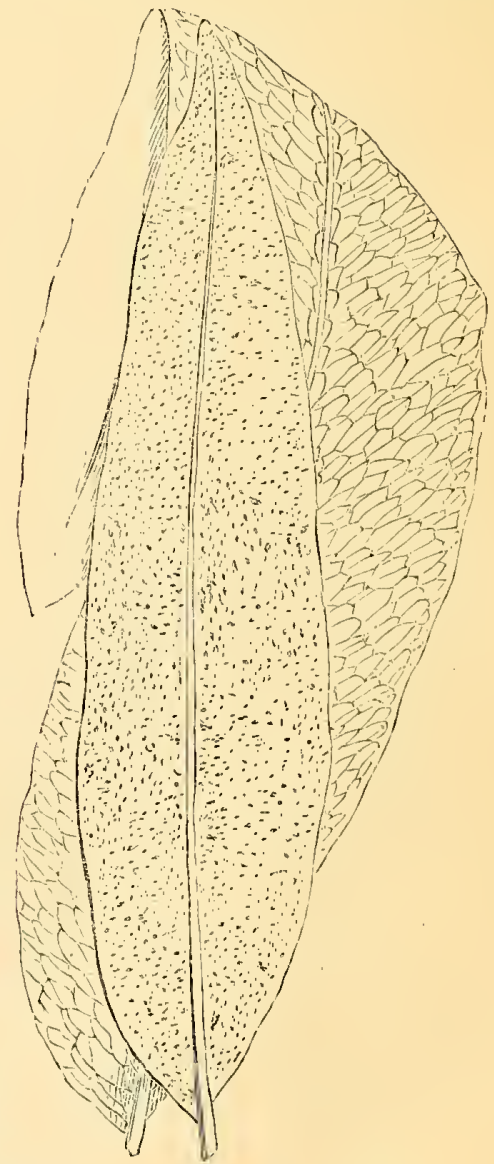

I'ig. 28. 


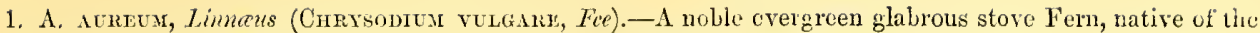
West Indics, tropieal Ameriea, Natal, and the East Indian and Polynesian Islands. Sterile fronds pinnate, six to eight feet long, reclining; pinure lanceolate-acuminate, rather membranous, light green, the lower ones petiolate, cuneate at the base, the upper adnate at the inferior base, and deeurrent. Fertile frouds contraeted, erect, lanceolate, piunate, from six to eight feet high, soriferous throughout; or with two or three of the lower pairs of pinuæ sterile. The fronds are terminal, adherent to an ereet eaudiciform rhizome. Mr. Heward mentions of this speeies, that it is very plentiful in morasses and water-eourses in the lowlands of Jamaiea, and never occurring at any great elevation above the sea shore. In cultivation, it requires a mixture of turfy loam and sand, abundanec of water, and a heat of $85^{\circ}$ or $90^{\circ}$ Falurenheit, and with this treatment will form a splendid object.

\section{PLA'TYYERIUM, Desean.}

Sori amorphons, produced in irregular patehes towards the extremities of the fertile fronds, or on a special lateral thickened lobe; sporangiferous receptacle formed of an accessory layer of parallel anastomosing veinlcts, which cross the sterile oncs, and produce crowded linear lines of spore-cases. Teins repcatedly forked, and distantly anastomosing ; venules internal, compoundly reticulated, with variously directed free veinlets, terminating in the areoles. Fronds simple, forked, coriaceous, thick and spongy; the sterile sessite, rounded or elongated, uniform, depressed or ascending, sublobate, permauent and successively imbricated, forming an clevated spongy mass; the fertile widening upwards, and dividing into broad forked segments. - Named from plat!'s, broad, and lieress, a horn; the fertile fronds resembling broad horns, as those of the elk.

The few specics of this genus have an cpiphytal habit, and produce their fertile fronds annually; thesc are attached by an articulation, and when mature fall spontaneously, the persistent depressed alternate sterile ones then having the appearance of a lichen or fungus. In the absenec of fructification, the genus is readily known by the stellate prbesconce that covers the whole surfuce. Fig. 29 represcnts a portion of the fertile frond of Pletycerium alcicorne (med. size).

1. P. alcicolrne, Desvaux (Acrostichur, Swartz; Nevroplatyceros, Fe; Alcicorniex vulgare, Gandichaud).-A very singular epiphytal evergreen Fern, a native of Madagasear, Java, and New Holland, requiring to be eultivated in a warm greenhouse. Sterile fronds sessile, round or elongated, the upper portion sublobate, permanent, elevated, spongy, reniform, and depressed. Fertile fronds simple, divided, horizontal or oblique, thick and eoriaecous, twelve to fifteen inches long, widening upwards, white on the under surfaee, and artieulated on a slort slightly ereeping rhizome. Sori amorphous in patehes, oeeupying the lobes or extremities of the fronds, whieh, as in the other speeies, are densely covered throughout with a stellate pubeseence.

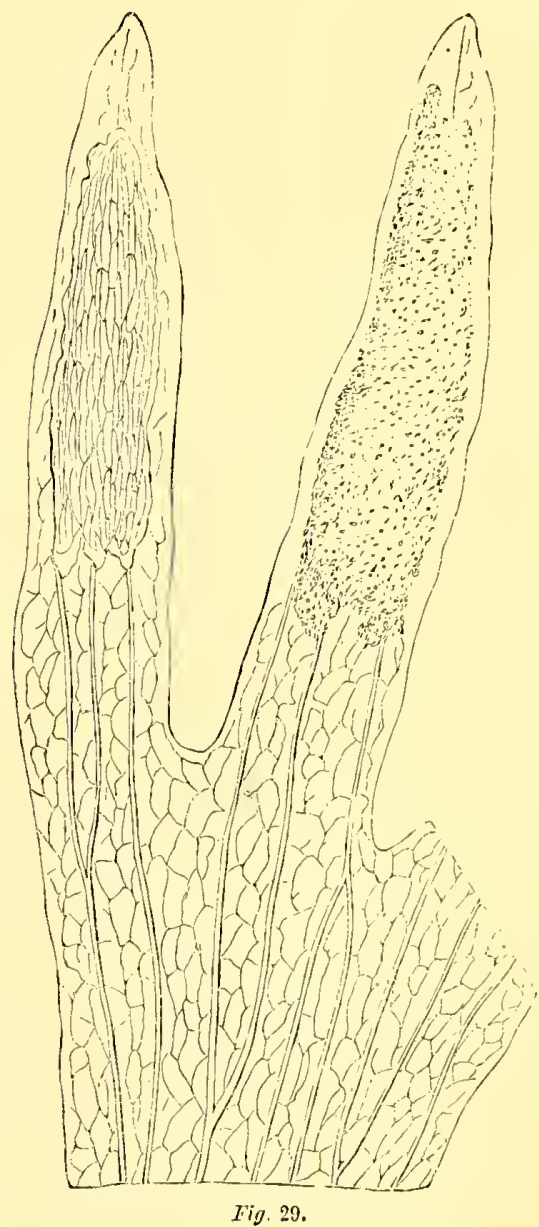

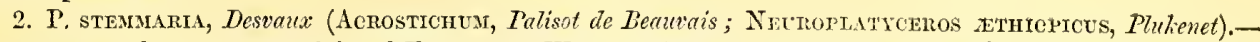
An ornamental evergreen epiphytal Fern, from Western Afriea. Sterile fronds sessile, elongated, ascerding, upper part scareely lobed, reniform, permancht, elevated, spongy and depressed. Fertile fronds simple, divided, horizontal, thiek and eoriaeeous, one to two feet long, widening upwards, and articulated with the rhizome. Sori occupying the lobes.

3. P. grande, J. Sinith (Acrostreruar, A. Cemingham; Neuroptatyceros, Fee; Platrcerium biforue, IIooker in Comp. to Bot. Mrag, - in part).-One of the most singular of all Ferns. It is an epiplytal evergrecn 
stuve species, a native of New Holland and the Malayan Islands. Sterile fronds sessile, reniform, round or elongated, aseending, two to two and a half feet high, the upper portion dividing into many broad blunt segments permanent, elevated, spongy, and depressed. Fertile fronds simple, two to three times divided, horizontal and pendulous, thick and coriaceous, two and a half or three feet long, widening upwards, articulated on a short rhizome. Sori in a large irregularly triangular pateh, adjaeent to the sinus of the first fureation of the fronds.

\section{CYRTOGONIUM, J. Smith.}

Sori amorphous, universal on the under side of the eontracted fertile fronds, or sometimes crowded on the renulcs. Teins pinnate; venules areuately or angularly anastomosing, produeing from their

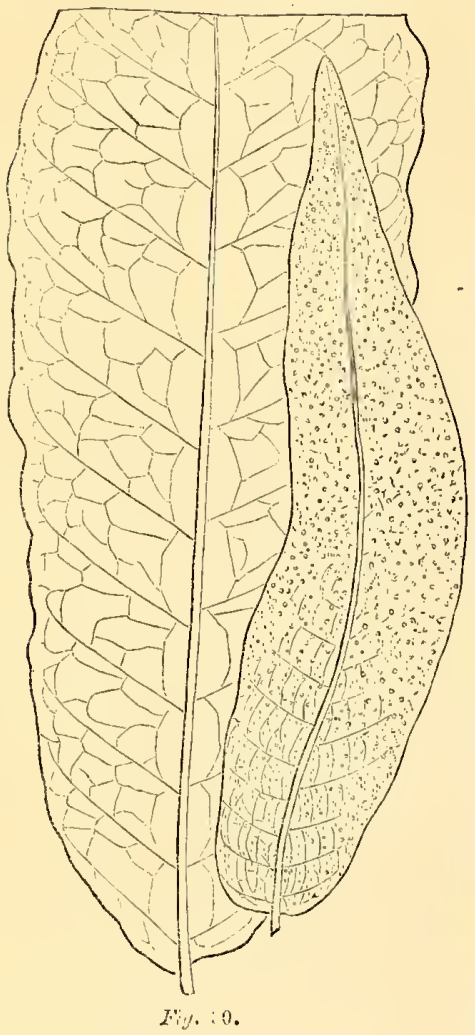
exterior sides or angles of meeting, one or more excurrent free or irregularly anastomosing veinlets. Fronds pinnate, from one to two feet long. Rhizome ereeping.-Named from kyrtos, eurved, and gonu, the knee; in allusion to the peeuliar knee-bent curve of the venules.

The aspeet of the speeies of Cyrtogonium varies but little from that of Gymnopteris; the prineipal distinguishing eharacter, is their more simple anastomosing venation. Fig. 20 represents the base of a pinna of the sterile, and a pinna of the fertile fronds of Cyrtogonium flagelliferum (nat. size).

1. C. flagieldifertar, J. Smith (Aerostrehtis, Wallich; Heteroxeuron heterochiton, Fee; Pecilopteris heteroclita, Presl).A proliferous, free growing, evergreen stove Fern, from the East Indies. Sterile fronds glabrous, rather membranous, pinnate, from one and a half to two and a half feet long; pinnæ petiolate, ovate or oblong-aeuminate, undulated, the terminal one a foot or more long; narrowing upwards, and proliferous near the apex. Fertile fronds eontracted, ereet, pinnate, from one to one and a half foot high; linnze oblong-acuminate, petiolate, the terminal one narrow and elongate. Both forms are lateral, adherent to a ereeping rlizome.

2. C. repandum, J. Simith (Acrostrchum, Bhme; Campium, Presl; Heteroneuron, Fee).--A glabrous evergreen stove Fern, from the East Indies and Java. Sterile fronds slender, reclining, triangular-elongate, pinnate, one and a half to two feet long, membranous, bright green; pinne proliferous, repand, ovate-acuminate, petiolate, deeply erenate, or slightly lobed, undulate, the terminal one sinuose, elongate. Fertile fronds ereet, pinnate; pinnæ oblong-acuminate, and petiolate. Stipes with a few scattered scales. Both sterile and fertile fronds are lateral, adherent to a creeping rhizome. This species has been recently introdueed by Messrs. Rollisson, of Tooting, from Java.

3. C. crispatulusi, J. Smith (Aerostiehum, Wallich).-A very handsome evergreen stove Fern, from Ceylon. Fronds rather erect, somewhat laneeolate, broad at the base, acuminate, pinnate, one to two feet long, deep green; pinnæ linear-acuminate, petiolate, glabrous, undulated, the margin erenate, with a row of spinulose teeth, one to each marginal sinus. Fertile fronds erect, pinnate, one foot high; pinnæ narrow, and petiolate. Both forms are lateral, with a scaly stipes, adherent to a ereeping, sealy rhizome.

\section{GYMNOPTEKIS, Bernhardi.}

Sor $i$ amorphous, densely eovering some portion or the whole of the fertile pinna. Teins pinnate; venules eompoundly anastomosing, produeing variously directed straight or curved free veinlets, terminating in the areoles. Fronds simple or pinnate, from one to three feet long. Rhizome creeping.-Named from gymnos, naked, and pteris, a fern; alluding to the exposed fertile fronds. 
The species of Gymnopteris mostly agree in habit with Cyrtogonium; but they are distinguished by the more irregular and compound anastomosing of the venules. The genus contains ten or trrelve species, but only three are at present in cultivation. Fig. 31 represents a portion of the sterile frond, and a pinna of the fertile frond, of $G$. nicotiancefolia (med. size).

1. G. Revoltta, $M I$. and $H$. (Hymenolepis, Blume; Hyalolepis, Kunze).-A singular.-looking evergreen stove Fern, from Java. Fronds simple, glabious, linear-lanceolate, nearly a foot long, light green, contracted and soriferous on the upper half, attenuated at the base, entire at the margin, becoming revolute, and partly concealing the sori during the early stages of tbeir development. Fronds lateral, articulated with a slender creeping rhizome. We are indebted to G. Norman, Esq, of Hull, for a cultivated specimen of tbis very remarkable Fern.

2. G. Decurrens, Fee (Leptochilus, Blume).-A singular evergrcen stove Fern, from Ceylon. Sterile fronds simple, glabrous, a foot long, lanceolate-acuminate, attenuated at the base, light green, and slightly undulated. Fertíle fronds simple, slender, linear, very narrow, one to two feet long, and one-eightb of an incb broad. Stipes one-half tbe length of the frond. Sori linear, continuous, forming a row on each nargin. Botb forms are lateral, articulated on a creeping rhizome about the size of a crow's quill.

3. G. nicotuanferolia, Presl (Acrostichum, Swartz). -An ornamental evergreen stove Fern, from the West

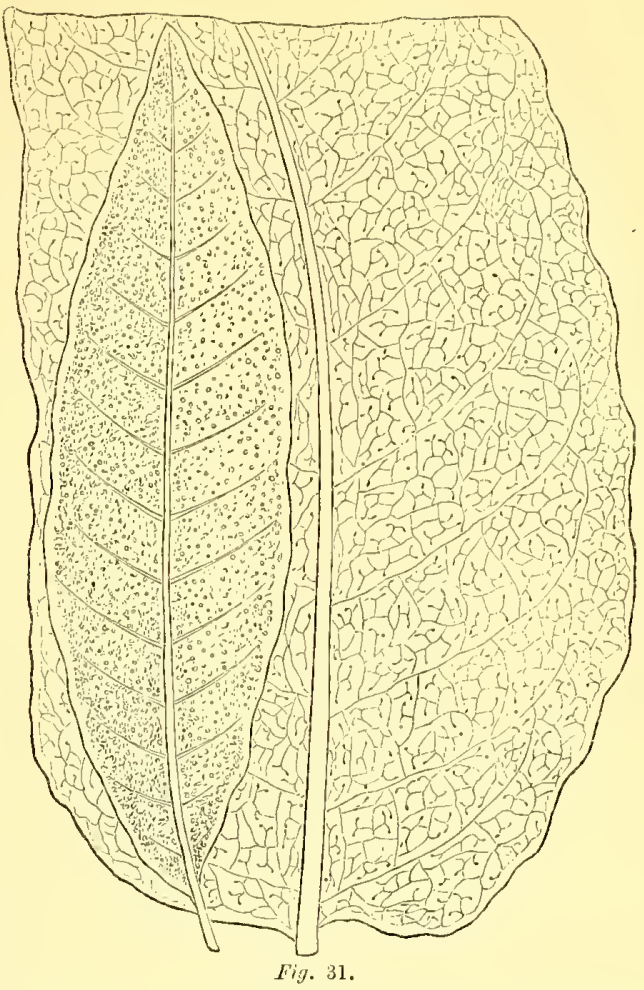
Indies. Sterile fronds glabrous, triangular, pinnate, one to two and a half feet long, brigbe green, and shining; pinnæ large, rather membranous, oblong-acuminate, undulated, the lower petiolate, and roundish at tbe base, the upper sessile, adnate on the lower side. Fcrtile fronds crect, pinnate, or occasionally bipinnate below, one to two feet bigh; pinnæ oblong-ovate, tbe lower petiolate, tbe upper sessile, adnate at tbe inferior base. Stipes sealy near tbe base. Botb forms are lateral, adherent witb a creeping rlizome.

Tribe Prenides, J. Smith.-Sori parallel with and situated on or near the margin or the costa, and furnished with a special indusium, having its inner margin free.

Ferns are very obviously divided into two groups, in one of which the sorus is furnished with a membrane, which at first completely covers it, and is termed an indusium or involucre; and in the other the sori are naked or without indusia. The Polypodiece and Acrostichece form the non-indusiate group. The Pteridece belong to the group which possess an indusium, and are characterized by having that organ produced on the exterior side of the sporangiferous receptacle, with its inner margin free, and with the spore-cases in its axis of attachment, or on its inferior disc. This tribe is represented by the genera Adiantum, Pteris, and Blechmum, of older authors, and is at once distinguished from Polypodiece and Acrostichere by the presence of the indusium, although closely allied to the latter tribe, through the genus Lomaria.

Sect. Chilosorex, J, Smith (from cheilos, a lip, and sorus.)-Sori margínal, continuous, or interrupted.

\section{ADIANTUM, Linnceus.}

Sori round reniform oblong or linear, marginal, continuous or interrupted. Indusium venose, formed of a reflexed crenule, reniform oblong or linear, according to the more or less crenulate or 
entire margin of the fronds, sporangiferous on its under surface, at length replicate. Costa excentric or wanting; veins unilateral, or radiating, forked; venules direct, terminating in the axis of the indusium. Fronds simple reniform, pinnate, pedate, bipinnate or decompound, from six inches to two or three feet high, smooth or hairy. Stipes and rachis usually ebeneous; pinnæe generally oblique, truncate or cuneate at the base, or dimidiate and soriferous on the upper margin only, petiolate, and usually articulated with the rachis or petiolc.-Named from adiantos, dry; alluding to a curious property oi the fronds, which repel moisture.

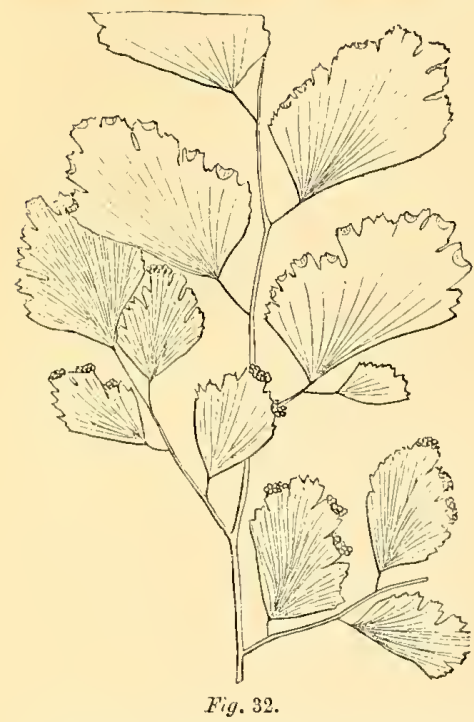

This very cxtensive and natural group contains upwards of a hundred known species, of graceful form, whose ebencous slenderishining stipes and rachis contrast admirably with the pinnæ, which are of a very delicate green colour. They have a very extensive geographical range, being found in the tropical and subtropical regions of both hemispheres, as well as in Europc, New Zealand, and North America. They hare a very close affinity with Cheilanthes and IIewardia, the latter a gerus not in cultivation. From the former they are distinguished by the position of the sori, whieh in Cheilanthes are situated on the apex of single venules in the axis of the indusium, whereas in Adiantum the sorus is placed on the indusium. From Hewardia they are distinguished by the latter having a reticulated renation. Fig. 32 represents a small portion of a frond of Adiantum tenerum (nat. sizc).

1. A. reniforme,-[Plate IV.]-Linnaus. $-\Lambda$ dwarf evergreen greenhouse Fern, from Madeira, and the Azores and Canaries. Fronds simple, round or reniform, glahrous, bright shining green, ahout six inches high, terminal, adherent to a scaly, somewhat crceping rhizome. Sori oblong, contiguous.

2. A. Wilsoni, Hooker.-An evergreen stove Fern, from Jamaica. Fronds glahrous, one foot long, simple, pinnate ; pinnæ ovate or oblong-acuminate, coriaccous, shining green, cordate at the base; the sterile ones hroad, serrate at the margin, petiolate, persistent and not articulate with the rachis; fertile fronds with from three to five pinnæ. Sori linear, continuous. Fronds lateral, adbcrent to a creeping rhizome ahout the size of a duck's quill.

3. A. ancrophyldum, Swartz.-A very beautiful evergreen stove species, from the West Indies and tropieal America. Fronds glabrous, ohlong-acuminate, hroad at the base, pinnate, one to one and a half foot long; pinnæ large, ovate or oblong, suh-sessile, acuminate, chartaceous, of a lively green, unequally cuneate at the hase, the sterile ones lohed and slightly dentate. Sori linear, continuous. This is rather an erect-growing plant, with the fronds lateral, adherent to a creeping rhizome.

4. A. Lucldus, Swartz.-A glahrous evergreen stove Fern, native of the West Indies and South America. Fronds lanceolate, pinuate, one foot long; pinnæ trapezio-lanceolate, acuminate, coriaceous, bright green, shining, truncate, and parallel with the rachis at the upper hase, the lower cuneate, the margin serrate. Rachis and stipes very hairy; lateral, adherent to a slender creeping rhizome. Sori linear, continuous, or sometimes interrupted.

5. A. Kaulfussit, Tímze (A. obliquun, Hooker and Greville, not Willdenow-fide Hooker). -A glabrous cvergreen stove species, from the West Indies and South America. Fronds lanceolate, pinnate, one foot long; pinnæ ovate-oblong, acuminate, deep green on the upper surfaee, and glaucous heneath, the inferior hase truncate, the superior rounded and slightly auriculate, margin serrate. Sori ohleng, linear, numerous throughout each fertile pinna. Fronds nearly all fertile, lateral, adherent to a slender crecping rhizome. Rachis and stipes hairy.

6. A. Lunulatum, Burmann (A. arcuaturi, Swartz).-An elegant, deciduous stove Fern, from the East Indies, Ceylon, Africa, and South America. Sterile fronds glahrous, piunate, pendulous, a foot or more long, and rooting at the apex; pinnæ ohlong-dimidiate, hright green, lobed on the upper margin, and obtuse at the base. Fertile fronds erect, narrow-lanceolatc, a foot or more long, glabrous, pinnate; pinnæ with long petioles, lunate on the upper margin, truncate-cuneate at the base. Sori ohlong-linear, often confluent. Fronds terminal, adhercnt to a fasciculatc rhizome.

7. A. caudatum, Limneus (A. hirsutum, Bory; A. flagliliferum, Wallieh).-A neat evergreen stove species, from India, Ceylon, China, and the Mauritius. Fronds hairy, narrow linear-lanccolate, clongate, 
pinnate, one to two feet long, void of pinnæ near the apex, and rooting at the point; pinnæoblong-dimidiate, numerous, subimbricate, lower ones flabellate, round at the apes, the upper margin divider into small dilatate segments or inciso-serrate, the lower entire, the base truncate, parallel with and close to the rachis. Sori small, numerous, crowded on the upper margin, and around the apex. Indusium small, scale-like, and very hairy. Raehis and stipes light brown. Fronds terminal, adherent to a small erect rlizome.

8. A. internedium, Swartz (A. Fovearum, Raddi; A. BRAsiliense, Linh). -An ornamental evergreen stove Fern, native of tropical America and the West Indian Islands. Fronds bipinnate, a foot or more long; pinnx lanceolate, five to seven in number; pinnules oblong, obtuse at the apex, membranous, light green above, rather glaueous beneath, the terminal pinnule subrhomboidal ; the sterile ones serrate. Sori oblong-linear, contiguous, produced on the upper and lower margins. Raehis and stipes slightly hairy; lateral, adherent to a slender ereeping rhizome.

9. A. Schomburgkranum, J. Smith.-A neat-looking evergreen stove Fern, from South America. Fronds sub-glabrous, slender, bipinnate, about a foot long, brigbt green; pinnæ lanceolate, four to six inches long; pinnules rather small and membranous, the lower ones flabellate, the rest oblong; dimidiate, the base truneate, parallel with and elose to the rachis, the upper margin erenate-serrate, the lower straight or slightly eurved, obtuse and serrate at the apex. Sori oblong, slightly eurved, five to ten on the upper margiu and around the apex. Rachis, stipes, and midrib of pinnæe thinly seattered over with rusty down. Fronds lateral, adherent to a slender creeping rhizome.

10. A. villosum, Limans. - A beautiful evergreen hothouse Fern, from the West Indies and South America. Fronds bipinnate, with tbree to six pairs of pinme, one to one and a half foot long, lightish green; pinnm lanceolate; pinnules petiolulate, subcoriaceous, dimidiate-oblong or forming an oblique parallelogram, lower ones small subflabellate, terminal one rhomboidal; upper base truncate and parallel with the rachis, lower dimidiate. Sterile pinnules broad, rolmdish at the apex, inciso-serrate at the margin. Sori linear, continuous on the upper margin, and round the apex of the pinnules. Rachis and midrib of pinnæ covered with rusty hairlike seales. Fronds lateral, adherent to a creeping rhizome.

11. A. Pulverulentun, Linnous.-An ornamental evergreen stove Fern, from the West Indies and South America. Fronds slender, bipinnate, with four to six pairs of pinnæ, one to one and a half foot long, bright green; pinnæ linear-laneeolate; pinnules rather small, petiolulate, dimidiate-oblong, subfalcate; upper base truneate and parallel with the rachis, lower dimidiate, round at tbe apex, sharply serrate at the margin, terminal one narrow-elongate. Sori oblong, continuous, oceupying three-fourths of the upper margin only. Rachis and midrib of pinnæ covered with rusty down. Fronds lateral, adherent to a creeping rhizome.

12. A. PEDatum, Iinncus.-A very elegant deciduons frame or greenhouse species, from North Ameriea. Fronds glabrous, a foot or more high, pedately tripartite, branches linear-lanceolate, pinnate; pinnules membranous, tender green, dimidiate, oblong obtuse at the apex; emneate or truneate at the base, the upper margin lobate or obtusely crenate. Sori oblong, solitary. Fronds lateral, on a short creeping rhizome about the size of a duck's quill.

13. A. cunvatum, Faulfuss.-An extremely elegant evergreen stove Fern, from Brazil. Fronds glabrous, one and a half to two feet high, pedately tripartite, brancbes lanceolate or linear-lanceolate, acuminate; pinnules narrow, curvate, oblong-obtuse, imbrieate, deorsely falcate, the superior margin inciso-serrate or crenate, the apex serrate, and more or less acuminate. Sori solitary, oblong. Fronds lateral, adherent to a creeping rhizome.

14. A. Flabellulatum, Limaus (A. Anicnum, Wallich).-A neat low-growing evergreen warm greenhouso or stove Fern, from China and the East Indies. Fronds subglabrous, flabellate, bipartito-pedately-divided, tripinnate, from nine inches to a foot high, dark green above and glaucous beneath; pinnæ lanceolate-acuminate; pinnules obliquely cuneate, repand, inferior ones semiorbicular-cuneate; superior base truncate; sterile margin serrate-dentate, fertile, two to four lobed, the lobes soriferous. Indusium large, the breadth of the lobes. Rachis pubeseent. Stipes ebeneous, terminal, adherent to a creeping rhizome. This speeies was introduced to Kew in 1851 .

15. A. yispidulum, Swartz (A. Pubescens, Schkuhr; A. Plica tum, haulfuss; A. nervosum, Suartz).-An ornamental evergreen greenhouse species, from New Holland, New Zealand, the East Indies, \&e. Fronds pubescent, one foot high, pedately tripartite, branches linear, narrow, acuminate, piunate, of a deep green; pinnules numerous, dimidiate, oblong obtusc, cuneate or truneate at the base, slightly serrate or crenate on the npper margin. Sori small, numerous; indusium bairy and reniform. Fronds nearly all fertile, lateral or terminal, on a short somewhat tufted rhizome.

16. A. tenselum, $T$. $M$. (A. hispidulum, of gardens, not of Swartz;? A. hispidulum, Brown).-A pretty little evergreen greenhouse speeies, supposed to be a native of New Holland. Fronds small, rather hairy, bi-tripinnate, lower branehes bipartite, pinnate above, six or eight inches high, branehes small, narrow, and slender; pinnules small, subrotund or oblong obtuse, dark green, cuneate or truncate at the base, the margin crenate. Sori small; indusium reniform. Fronds lateral, adherent to a slender ereeping rhizome. This species, long known in gardens as the A. Hispidulum, is not the plant of Swartz, as Sir W.J. Hooker has shown, that being the A. pubescens of gardens. Whether it be the plant so ealled by Mr. Brown, as has been suspected, we have no means of ascertaining. It is eertainly and abundantly distinct from the true hispidulum.

17. A. Affine, Willdenow (A. setulosun, $J$. Smith).-A neat evergreen stove Fern, from New Zealand and Norfolk Island, Fronds about a foot high, three-branched or subpedate, lower pinnæ bipartite; pinuules 
dimidiate, eurved, oblong-obtuse, membranous, tender green, with black bristle-like hairs on the upper surfaee, superior margin obtusely erenate. Sori punctiform, from four to six on cacli pinnule; indusium hairy, reniform. Rachis and stipes glabrous; lateral, adherent to a slender erecping rhizome, forming dense tufts.

18. A. cristatum, Limeus (A. stritum, Swarlz; A. villosur, of some gardens).-A beautiful evergreen stove species, from Jamaiea. Fronds glabrous, bipinnate, one foot long; pinnæ linear-acuminate, narrow, six or eight inches long, pendulous; pinnules small, dimidiate, rigid, obtuse, imbricate, deep green, and truneate at the base. Sori oblong, subeontiguous, one to four on the upper margin only. Stipes dull black, minutely nurieated; lateral, adherent to a short creeping sealy rhizome. This species is sometimes cultivated under the name of $A$. villosum.

19. A. Capillus-veneris, Limaus (A. Monitzianum, Linli).-A dwarf evergreen frame or greenhouse Fern, indigenous to Britain, common in the south of Europe, and occurring in the East Indies, Mauritius, China, North and South Africa, the Canaries, the temperate parts of North America and Central America, and the Cape de Verd Islands. Fronds glabrous, membranous, tender green, usually somcwhat ovate, bi-tri-pinnate, six or eight inches high; pinnules obovate-cuneate, inciso-sublobate, serrate at the margin. Sori oblong. Frends lateral, adherent to a scaly creeping rhizome. Tlis species, although indigenous to Britain, is one of those delicate Ferns that cannot be cultivated in exposed places, for if planted in such situations it invariably dwindles away, and is soou lost. It grows freely in a close frame, or in a greenhouse where the atmosphere is kept moist. In the warmer climate of Madeira, and the tropics, it attains the height of eighteen inches, and in this state has been called $A$. Moritzicmum; but the native plant, if eultivated in a moist stove with a high temperature, will produce fronds of equal magnitude, and identical in structure.

20. A. Assmile, Swartz.-A very neat and delicately beautiful evergreen greenhouse Fern, from New Holland and New Zealand. Fronds slender, glabrous, broadly lanceolate, tripinnate, a foot or more long; pinnules small, somewhat roundish or subrhomboidal, cuncate at the base, bright green, and slightly lobed or erenate at the margin. Sori small; indusium reniform. Fronds lateral, adherent to a slender creeping rlizome.

21. A. cuneatum, Langsdorf and Fischer.-An evergreen stove Fern, from Brazil. Fronds glabrous, triangularly elongate, three or four times pinnate, a foot or more high; branches very slender, and of a light green ; pinnules small, numerous, oblong, wedge-shaped, inciso-sublobate, sterile lobes serrulate, fertile emarginate. Sori small; indusium reniform. This species is one of the most delicately heautiful of the genus; the fronds grow rather erect, and are adherent to a somewhat tufted rhizome. It is sometimes called $A$. pedulinum.

22. A. concinnum, Humboldt, Bonpland, and Tunth.-A very graeeful pendulous evergreen stove species, from the West Indies, Venezuela, and other parts of South and Central America. Fronds slender, glabrous, laneeolate, tripimnatc, two to three feet long; pinnules somewhat round or rhomboidal, membranous, tender green, obtuse with crenate lobes, the lowest erect and appressed to the rachis. Sori small, numerous; indusium reniform. Fronds lateral, adherent to a somewhat erecping rhizome.

23. A. chulense, fiaulfuss.-An elegant evergreen greenhouse Fern, from Chili, Valparaiso, and Juan Fernandez. Fronds ovate-deltoid, about one foot high, grass green, tripinnate; pinnules petiolulate, coriaceomembranous, hairy beneath, subrhombeo-reniform, more or less obliquely cuneated, often truneated at the base, the margin irregularly lobed, the lobes retuse, soriferous. Sori oblong.reniform, distant in the lobed pinnules, crowded in the more entire ones. Stipes and rachis ebeneous, glossy. Fronds lateral, adherent to a creeping rhizome. Recently introdueed to Kew from the Continent.

24. A. Fragite, Swartz.-A remarkable stove Fern, native of Jamaica. Fronds one to two feet long, bright green, ovate-lanceolate, tri-quadri-pinnate; pinnules thin, membranous, obovate wedge-shaped, petiolulate, ronnded at the apex, scrrated when sterile, three or four lobed when fertile, the fertile lobes retuse, and bearing a sorus in the sinus. Involneres oblong; straight. Stipes very short, and, as well as the rachis, ebeneous and glossy. Fronds adherent to a tufted rhizome. The pinnules in this species are remarkably deeidnous, being all cast off while drying.

25. A. Tenenum, Suartz.-A very elegant evergreen stove Fern, from the West Indies and Central America. Fronds glabrous, triangular, forr times pinnate, two to two and a half feet high; pinnules membranous, bright green, rhomboidal, obtuse at the apex, inciso-lobate; sterile lobes serrulate, fertile entire. Sori oblong-reniform. Fronds lateral, adherent to a short creeping rhizome, forming dense tufts.

26. A. Cunsingitami, Hooker (A. Afrive, of gurdens).-An ornamental evergreen greenhouse Fern, from New Zealand. Fronds glabrous, somewhit pentagonal, bi-tripinnate, twelve or fourteen inches high; pinnules dimidiate, oblong-obtuse, cuneate or truneate at the base, deep green, superior margin inciso-serrate. Sori numerous; indusium reniform. Stipes sealy near the base, lateral, adherent to a scaly creeping rhizome nearly the size of a crow's quill.

27. A. Formosum, R. Brown.-An ornamental evergreen greenhouse Fern, from New Holland. Fronds deltoid or pentagonal, branching, four times pinnate, one and a half to two feet high; pinnules small, membranous, rhomboidal, obtuse, ineiso-lobate, pale green, the sterile serrate; rachis pubescent. Sori small ; indusium reniform. Stipes seabrous, lateral, adhcrent to a slender creeping rhizome.

28. A. cultratum, J. Smith.-A very handsome stove Fern, native of Brazil. Fronds one and a balf to two feet or more high, glabrous, tripartitely bipinnate, that is, bipinnate with the lower pair of pinnæ two-parted; pinnules dull green, somewhat cordately rlomboid..oblong, the upper side and more or less attenuated apex lobed 
with serrated lobes, the lower margin recurvate. Sori small, narrow linear-oblong occupying the ajices of the lobes, and ehiefly produced on the upper margin. Stipes and raehis dark chesnut-eoloured when young, beeoming blackish when mature, at first sealy throughout with narrow deciduous seales; lateral, adherent to a ereeping rhizome. This species has been introduced to the Chelsea and some other gardens, from the establishment of M. Van Ioutte of Ghent, under the nanc of $A$. pentadactylon. It is allied to $A$. trapeziforme, but is a more slender plant, with a sealy brown-black raehis, narrower deorsely faleate pinnules, and smaller linear-oblong, not oblong-reniform, sori, and is wanting altogether in that delieate green eolour which in $A$. trapeziforme is so strikingly contrasted with the ebony-black smooth stipes; the pinnules, moreover, are scareely at all glaueous beneath.

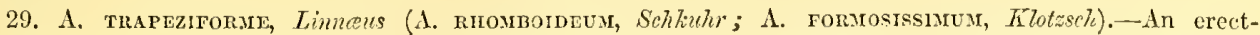
growing evergreen stove Fern, from Jamaiea and other West India Islands, and South Anerica. Fronds glabrous, pentagonal, four times pinnate, two to three feet high; pinnules large, bright green, ovato-rhumboidal, acuminate, the apiees serrate and sub-crenate. Sori large, oblong; indusium reniform. This is a vory beautiful Fern, from the contrast of its large delieate green pinnules with the shining black stipes and raehis. The fronds are lateral, adherent to a thiek sealy erceping rlizome.

\section{CHEILAN'THES, Swartz.}

Sor $i$ round, marginal, solitary or contiguous, often becoming confluent. Indusium sometimes reniform, rarely oblong, and ineluding more than one sorus. Veins forked; eenules dircet, their apices fice, and sporangiferous. Fronds from a few inches to two or three feet long, glabrous, pilose, glandulose, or squamose; segments of the pinuules sometines very small, coneave, and orbieular.-Named from chcilos, a lip, and anthos, a flower; in allusion to the lip-formed indusium which eovers the fructifieation.

With one or two exceptions, the species of Cheilanthes are small plants, less than a foot in height; they are all of very delicate texture, and are mostly natives of elevated regions in tropical or subtropical countries. They are best cultivated in an intermediate house, and should be potted in sandy peat soil, well drained; water being rery sparingly used over the fronds. During winter they should be kept rather dry. The species are often very dificult to determine, unless examined in

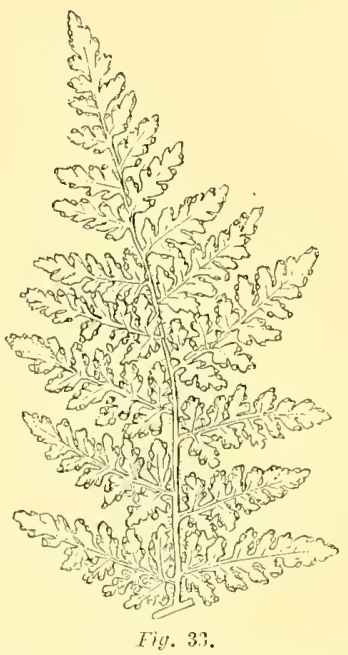
a living state. In the small convex segments of the pinules, and the paucity of spore-enses,

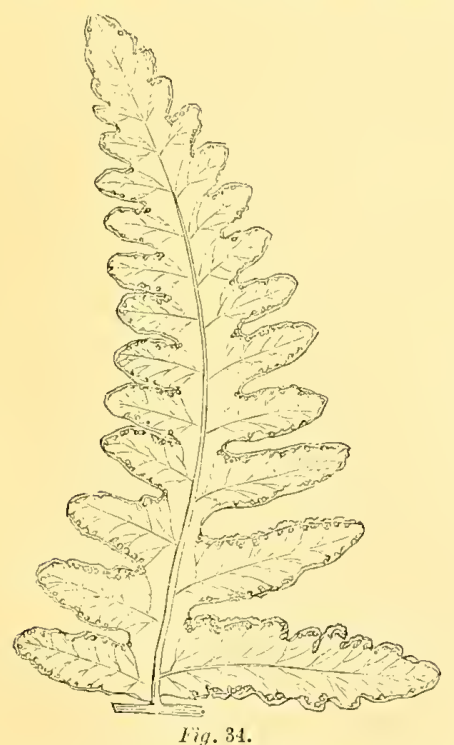

universal throughout every segment of the frond. Fig. 34 represents a full-sized pinnule of tlis species.

they are analogous to Nothochlena, but from that genus they are distingnished by the presence of an indusium. From Adiantum they are known by the position of the sori, whieh is here produced on the apex of the venules in the axis of the indusium, that of Adiantum being on the indusium. Fig. 33 represents a small portion of a frond of Cheilanthes visrosa (nat. size).

1. C. Mcroptenis, Sicartz.-A neat dwarf evergreen greenhouse Fern, from Quito, Brazil, and the Argentine provinees. Fronds slender, linear, four to six inches long, and eovered throughout with glandulose hairs, pinnate; rinnæ numerous, small, petiolate, light green, subrotund, coneave, and suberenate. Raehis and stipes brown, terminal, adherent to a slender creeping rhizome. Sori eonsisting of a few spore-cases on eaeh segment, which ultimately beeome eonfluent.

2. C. Fanixosa, Tanlfuss (PteRis, Forskal and Sicartz; CAssereera, J. Smith; Allosorus, Prest; C. Dealbata, Don; Pteris ARGTROPHYLLA, Swartz).-An exceedingly beautiful evergreen stove Fern, from Nepal. Fronds glabrous, triangular, one to one and a half foot long, bipinnatifi; segments oblong-obtuse, the upper surface dull green; densely eovered bencath with a white farinose powder. Rachis and stipes ebeneous; terminal, adherent to a faseiculate erect rhizome. Sori linear, eontinuous, subsequently confluent; indusium 
3. C. Fragrans, Trebb and Berthelot (C. odora, Swartz; C. suaveolens, Swartz; C. Maderensis, Lowe).-A dwarf evergreen greenhouse Fcrn, from the South of Europe. Fronds glabrous, triangularly elongate, bipinnate, about six inches high, of a light green; pinnæ oblong-obtuse, siruate-pinnatifid, the lower ones distant and pinnatifid. Rachis and stipes scattered over with narrow scales. Sori confluent. Fronds terminal, adherent to a somewhat tufted rhizome.

4. C. Micropiylla, Swartz.-An ornamental evergreen stove Fern, from the West Indies. Fronds slender, somewhat lanceolate, broad at the base, bipinnate, one to one and a half foot long, pale green, slightly pubcsccnt; pinnules oblong, rather obtuse; segments roundish-ovate, the sterile ones dentate. Raclis and stipes ebeneous, terminal, adherent to a short creeping rhizome. Sori continuous, eonfluent; indusium very small.

5. C. alabamensis, hunze (Preris, Buchley; P. Gracilis, Rugel).-An ornamental evergreen greenhouse Fern, from the Southern United States of America. Fronds glabrous, subcoriaceous, ten to twelve inches high, lanceolate, acuminate, bipinnate below; pinnæ ovate-lanceolate acuminate ; pinnules of the lowest pinnæ almost again pinnate the segments oblong-obtusc, of the upper ones entire, or auricled, or lobed at the base. Stipes and rachis deep glossy black, adherent to a creeping rhizome. Sori continuous on the lobes and pinnules.

6. C. mcromera, Link.-An evergrecn greenhouse species, from Mexico. Fronds lanceolate-acuminate, bipinnate, about a foot long; pinnx linear-acuminate, pinnules rather obtuse; segnents obovate, deep green, the sterile crenate. Stipes, rachis, and midrib of pinna ebeneous, and covered with narrow brown scales; fertile segments concave. Sori continuous, confluent; indusium very small. Fronds nearly all fertile, terminal, adherent to a short creeping rhizome. This is certainly distinct from C. microphylla.

7. C. profusa, Tunze (Nothochlena pumlla, of gardens). -A warm greenhonse Fern, native of Namagua Land. Fronds slender, lanceolate, bi-tri-pinnate, six to ten inches long, light green; pinnules oblong, rather obtuse, segments adnate, subdecurrent at the base, erenate at the margin. Sori confluent. Rachis, midrib of pinnæ, and pinnules, scattered over with narrow elongated light brown seales. Fronds terminal, adherent to a slender crceping rhizome.

8. C. Hikta, Swartz.-A very delicate erergreen greenhouse species, from the Cape of Good Hope. Fronds linear, lanceolate, subtripinnate, one foot long, pale green, and covered throughout with glandulose hairs; pinnules small, oblong-obtuse, pinnatifid; segments crenate. Rachis and stipes brown, terminal, adherent to a rather erect rhizome. Sori distinct, subsequently confluent, on each segment of the fertile fronds.

9. C. Tenuifolia, Swartz.-A very tender deciduous greenhouse Fern, from the East Indies and New Holland. Fronds somewhat ovate or triangularly elongate, tripinnate, one foot long, light green; pimnules linear-acuminate; seginents oblong-ovate, deflexed. Rachis, stipes, and midrib of pinnæ brown, and scattered over with narrow scales. Fronds terminal, adherent to a creeping rhizome. Sori round, subsequently confluent; indusium very small.

10. C. Exilss M. \& H.-A delicate deciduous warm greenhouse Fern, the native country of which is unknown. Fronds very slender, glabrous, linear-oblong, one foot or more long, bi-tri-pinnate, lightish green ; pinnæ ovatetriangular; pinnules oblong, pinnatifid; scgments small, linear-oblong, adnate-decurrent at the base. Sori erowded on the teeth or scgments. Rachis and stipes of a shining brown. Fronds terminal, adherent to a slender crecping rhizome. This Fern differs from C. tenuifolia, to which it is allied, in its slender and narrowlyelongated form; and from $C$. Siebcri, which it resembles in outline, in its more delicate habit and texture: indeed we should have been inclined to refer it to the latter species, were it not that it never assumes any degree of stoutness and rigidity, but is slender, fragile, and membranous, and of very delicate constitution.

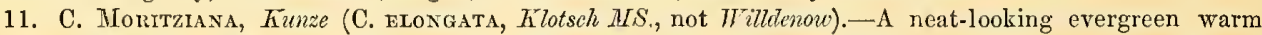
greenhouse Fern, from Mexico and Venezuela. Fronds glabrous, triangularly elongate, tripinnate, nine inches to a foot long, lively green; pinnules remote, deeply pinnatifid, with small roundish ovate segments, inferior ones entire, superior decurrent at the base, crenulate on the margin. Sori small, but few spore-cases on each segment. Stipes, rachis, and midrib of pinnæ shining; terminal, adherent to a crecping rlizome. This species has been introduced under the name of C. elongata by G. Norman, Esq.; of Hull, from the Continental gardens.

12. C. marginata, Humboldt, Bonpland, and Timth (C. mufescens, Link; C. chinophylla, Tunze; Allosorus cilistus, Presl).-A very neat, evergreen, greenhouse Fern, from the Peruvian Andes and other parts of South America, and the West Indies. Fronds glabrous, somewhat ovate-triangular, from six to ten inches hịg, delicate green, tripinnatc; pinnules oblong, with oblong-ovate rather obtuse segments, decurrent at the base. Stipes and rachis black; rhizome somewhat creeping. This plant is now very scarce in cultivation; although, in 1840 , it was growing freely in the Birmingham Botanic Garden.

13. C. cuneata, Lim (CAssebeera, J. Smith).-A neat evergreen greenbouse Fern, from Mexico. Fronds glabrous, triangular, bipinnate, six to ten inches high, of a lively green; fertile pinnules oblong-acuminate, pinnatifid, with the segments narrowed at the base; sterile segments oblong, wedge-shaped, and serrate at the margin. Sori linear continuous. Rachis and stipes ebeneous; rhizomc somewhat creeping.

14. C. viscoss, Link.-A beautiful evergrcen stove species, from Central America. Fronds triangular or pentagonal, one foot high; ; branches tripinnate, light grcen, and covered throughout with viscid glandulose hairs; pinnules oblong-obtuse, pinnatifid; segments of the sterile frond dentate. Sori linear, continuous around evcry segment of the fertile fronds. Raehis and stipes brown, terminal, adherent to a short creeping rhizome.

15. C. Lfspigera, Sirntz (C. I.tentigera, Willdenor().-An clegant cvergreen stove species, from Quito, 
Mexico, aud other parts of South America. Fronds ovate-lanceolate, tripinnate, one foot long, with copious soft hair-like scales; pinnules oblong; segments small, roundish ovate, cuneate at the base, crenate, reflexcd, and coneave. Sori linear, consisting of a single row of spore-cases, partly concealed in the axis of the broadly reflexed margin of each segment; indusium linear, continuous. Fronds terminal, adherent to a creeping rhizome.

16. C. elegans, Desvaux (C. Lendigrra, of gardens).-An exquisitely beautiful evergreen stove Fern, a native of Chili, Mexico, the Peruvian Andes, and other parts of South America. Fronds lanceolate tripinnate, one foot long, clothed with copious brownish chaffy scales; pinnules oblong-linear; segments very small, obovate, revolute and concave. Sori consisting of two or three spore-cases on each segment, partly concealcd by the reflexed margin. Stipes, rachis, midrib of pinnæ, and pinnules, densely covered with brown fringed scales. Fronds terminal, adherent to a short creeping rhizome.

17. C. spectabilis, Kaulfuss (C. BRasiliensis, Raddi; Hypolepis, Hooker).-A straggling-growing evergreen stove Fern, native of Brazil. Fronds slender, glabrous, oblong-acuminate, broad at the base, tripinnate, three to four feet long, light green; pinnæ linear-acuminate; pinnules oblong-linear; segments oblong-obtuse, slightly crenate, adnate and decurrent throughout the whole frond. Stipes and rachis ebeneous, glossy, terminal, adherent to an erect fasciculate rhizome. Sori distinct, subsequently confluent.

18. C. Radiata. J. Smith (Adtaxtum, Linncus; Hypolepis, Hooker).-A delicate and exceedingly beautiful evergreen species, native of the West Indies and tropieal America. Fronds glabrous, one foot high, digitate; branches linear, pinnate, radiating; segments oblong-obtuse, subimbricate, petiolate, articulate at the base, auriculate, with a crenate margin. Sori distinct, often crowded throughout the frond; indusium reniform. Rachis and stipes ebeneous; terminal, adherent to an crect fasciculate rhizome.

19. C. Pteroides, Swartz (Cassebeera, Presl; Adintum, Linneus; Pteris orbiculata, Houttyn).-An ornamental evergreen warm greenhouse Fcrn, from the Cape of Good Hope. Fronds somewhat triangular, glabrous, one to one and a half foot long, bipinnate, light green; pinnules ovate-elliptical, petiolate, round at the apex, slightly cordate at the base, and crenulate on the margin. Sori marginal. Iudusium membranous, scalelike, contiguous. Stipes and rachis shining, especially when dry. Fronds adherent to a somewhat creeping rhizome. 'The only cultivated frond of this plant we have seen, was communicated by G. Norman, Esq., of Hull.

XXXIII. HYPOLEPIS, Bernhardi.

Sori round, terminal, marginal, partly concealed by a reflexed indusioid crenule, and situate opposite the sinus of the segments. Veins forked or pinnate; venules direet, free, the lower exterior one sporangiferous. Fronds from two to six or twelve fect high, bi-tri-pinnate, segments crenulated, smooth, or covered with glandulose hairs.-Name derived from hypo, under, and lepis, a scale; in allusion to the sori being placed under scale-like reflexed crenules.

This genus, formerly placed near Cheilunthes, among the Pteridee, was removed by Mr. J. Smith to the Polypodiece, and we had adopted Mr. Smith's view of its affinitics. It appenr's to us, however, on a reconsideration of the matter, that the plants which led Mr. Smitl to this opinion, though analogous in habit to the genuine species of Hypolepis, cannot properly be associated with them, no trace of an indusium being present; and the other characters of the plants bcing altogether those of Polypodium. We have, eonsequently, referred back to Polypodium the Iypolepis rugulosa (J. Smith), and retain Irypolepis itself among the Pteridea, where it was originally stationed. Fig. 35 represents a pinnule of IIypolepis dielisonioides (nat. size).

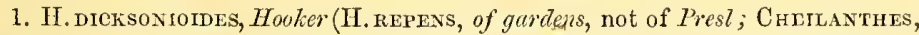
Endlicher; Ilypolepis Endicheriana, Fresl; Dicisonia davallioldes, Broum -according to Kinnze).-A large coarse-growing evergreen greenhouse Fern, native of Norfolk Island. Fronds triangularly elongate, from three to six, or even twelve feet high, covered with glandulons hairs; decompound, three or four times pinnate ;

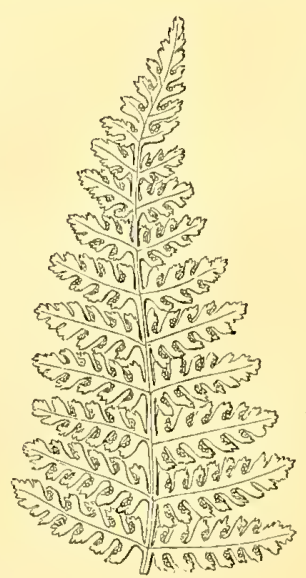

Fig. 35 . pinnules lanceolate-acuminate, with oblong-lincar rather obtuse pinnatifid segments, which are somewhat convex, the lower pair distant; margin crenulate. Sori round, termiual, and partly concealed by a reflexed marginal crenule. Fronds laterul, adhercnt to a scaly creeping rhizome.

2. H. PRAvA, $M I$. and $H$. $-\mathrm{A}$ very singular-looking and deformed-growing evergreen warm greenhouse or stove Fern, the origin of which is unknown. Fronds triangularly elongate, tripinnate, one to two fcet long, dull green, and covered throughout with glandulose hairs; pinnæ lanceclate; pinnules unequal, rugose, pinnatifid, with unequal segments, obtusely crenate. Sori very few, thinly seattered throughout the frond, which is lateral, adherent to a sleuder creeping sealy rhizome. Perhaps only a dwarf abuormal state of the former. 


\section{PLATYLOMA, J. Smith.}

Sori linear-oblong, continuous, subsequently confuent, occupying a portion of the upper half of the venules, forming a broad marginal band. Indusium narrow, attachcd transversely to the outer margin of the broad sporangiferous receptacle. Veins forked; venules direct, their apiccs free and sporangiferous. Fronds from one to two feet long, pinnate bipinnate or tripinnate, glabrous pilose or squamiferous; stipes gencrally ebeneous, pinnæ articulate with the rachis.-Name derived from piatys, broad, and loma, a margin ; in allusion to the broad marginal sori.

The species anranged under this genus, with one or two exceptions, vary but little in habit from those of Adiantum. The principal technical distinction is in the presence of a broad sporangiferous receptacle, with the margin of the frond slightly reflexed, and cdged with a narrow linear indusium, which is continued, more or less, throughout every pinna or pinnule of the whole frond. Fig. 36 rcpresents a portion of the frond of Platyloma falcata (med. size).

1. P. rotundifolia, J. Smith (P'teris, Forster; Allosonus, Kunze). - A pretty evergrcen greenhouse Fern, from New Zealand. Fronds linear, pinnate, one to one and a half foot long, reclining; pinnæ glabrous, dull green, coriaceous, subrotund or oblorig-elliptical, rather obtuse, cordate at the base, and slightly crenate at the margin. Rachis and stipes densely covered with brown scales; lateral, adherent to a creeping rhizome. Sori linear, continuous, very broad; iudusium very narrow. This seems to merge insensibly into the next species.

2. P. falcata, J. Smith (Pteurs, R. Brown; Allosorus, Kunze). -An ornamental evergreen greeuhouse species, from New Holland. Fronds lauceolate, pinnate, one to two feet high, rather erect; pinnæe glabrous, coriaceous, linear-lanceolate, oblong; bluntly acuminate, falcate, cordate at the base, and of a dull green colour. Rachis and stipes squamiferous; lateral, adherent to a creeping rhizome. Sori linear, continuous, very broad; indusium very narrow.

3. P. Brotwari, J. Smith (Adrantur Paladoxuri, R. Brown; Allosorus paradoxus, Tíunze; Pteris latizona, A. Cumingham). -An ornamental evergreen greenhouse Fern, from New Holland and New Zealand. Fronds ovate or ovate-oblong, erect, pinnate, one to two feet high, with from about seven to eleven large pinnæ near the

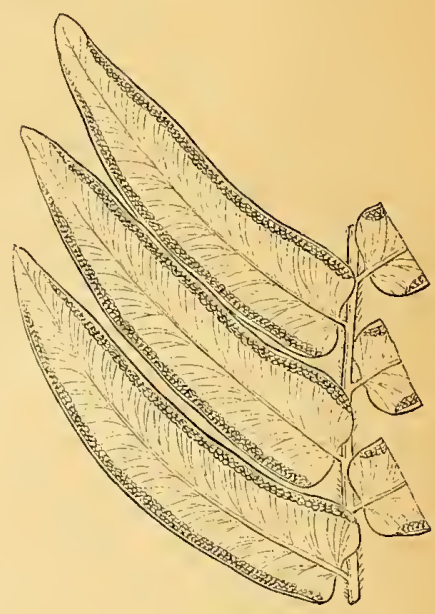

Fig. 36 . top; pinnæ alternate, cordato-oblong-lanceolate, somewhat oblique or subfalcate, thick, almost coriaccous, dull dark green above, paler and somewhat glaucous beneath. Sori broad, linear, continued along both sides of the pinnæ from the base to the apex. Indusium vcry narrow. Rachis and stipes purple-ebeneous, covered, the former espeeially, with appressed rust-coloured hair-like scales; lateral, adherent to a short creeping rhizome. The younger immature fronds are simple and cordate; and the stipes are two or three times as long as the leafy portion in the perfect fronds. This Fern has been recently imported from New Zealand by Messrs. Ilenderson, of the Edgeware Road.

4. P. ternitrolia, J. Smith (PTeris, Cavanilles; Pelimad, Linle; Pterrs subveliticillatus, Suartz; Allosonus supverticiliatus, Presi). $-A$ rather pendulous evergreen stove Fern, from Mexico. Fronds glabrous, bluish green, linear, pinnate, one to one and a half foot long, reclining; pinne cori ceous, opposite or alternate, sessile, trilobed, cordate at the base, with a cartilaginous margin. Sori linear, continuous; indusium very narrow. Rachis and stipes purple; stipes pubescent, termiual, adherent to a short scaly creeping rhizome.

5. P. Calonielanos, J. Smith (Pteris, Swartz; Petildsa, Linl; Allosorus, Presl).-A dwarf evergreen stove species, from the Cape of Good Hope. Fronds deltoid, bipinnate, about a foot long; pinnules deltoid, eoriaceous, quite smooth, glaucous, aud of a bluish green colour, cordate at the base, subtrilobate, with a narrow cartilaginous margin. Stipes scaly near the base, terminal, adherent to a short creeping rhizome. Sori linear, continued round every fertile pinnule; indusium very narrow.

6. P. atropurpurea, J. Smith (Pteris, Linnaus; PeLldzA, Linle; Allosonus, Limze).-[Plate V.]-An elegant dwarf evergreen frame or greenhouse species, native of North America. Fronds bluish green, ovate-lanceolate, bipinnate, six to ten inches long; pinnules glabrous, oblong or ovate, obtuse, cordate at the base, terminal one elongate. Sori linear, continuous, forming a broad band; indusium narrow. Rachis and stipes pubescent, terminal, adherent to a somewhat creeping rhizome.

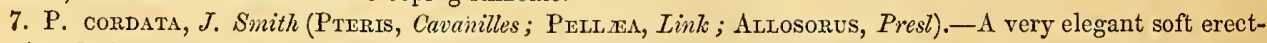
growing deciduous greenhouse Fern, from Mexico. Fronds delicate, light green, oblong-acuminatc, broad at the base, bipinnate, one and a half to two feet high; pinnulcs ovate, cordate-sagittate, membranous, and densely 



SMITHSONIAN INSTITUTION LIBRARIES

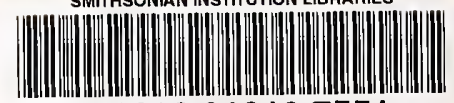

39088012127551 